UNIVERSIDADE DE SÃO PAULO

ESCOLA DE ENFERMAGEM DE RIBEIRÃO PRETO

RÚBIA DE AGUIAR ALENCAR

Pesquisa-ação sobre sexualidade e vulnerabilidade às IST/aids

com alunos de graduação em enfermagem

Ribeirão Preto 


\section{RÚBIA DE AGUIAR ALENCAR}

Pesquisa-ação sobre sexualidade e vulnerabilidade às IST/aids

com alunos de graduação em enfermagem

Dissertação apresentada ao Programa de PósGraduação em Enfermagem Psiquiátrica da Escola de Enfermagem de Ribeirão Preto da Universidade de São Paulo, para obtenção do título de Mestre em Enfermagem Psiquiátrica.

Área de concentração: Enfermagem Psiquiátrica.

Linha de pesquisa: Educação em Saúde e Formação de Recursos Humanos.

Orientadora: Prof ${ }^{\mathrm{a}} \mathrm{Dr}^{\mathrm{a}}$ Sônia Maria Villela Bueno.

\section{Ribeirão Preto}


AUTORIZO A REPRODUÇÃO E DIVULGAÇÃO TOTAL OU PARCIAL DESTE TRABALHO, POR QUALQUER MEIO CONVENCIONAL OU ELETRÔNICO, PARA FINS DE ESTUDO E PESQUISA, DESDE QUE CITADA A FONTE.

\section{FICHA CATALOGRÁFICA}

Alencar, Rúbia de Aguiar

Pesquisa-ação sobre sexualidade e vulnerabilidade às IST/aids com alunos de graduação em enfermagem. Ribeirão Preto.

143f.; il,; 30cm.

Dissertação (Mestrado) apresentada à Escola de Enfermagem de Ribeirão Preto/USP - Área de Concentração: Enfermagem Psiquiátrica Linha de Pesquisa: Educação em Saúde e Formação de Recursos Humanos.

Orientadora: Bueno, Sônia Maria Villela

1. Estudantes. 2. Enfermagem. 3. Sexualidade. 4. Comportamento sexual. 5. Educação para saúde 


\section{Folha de Aprovação}

Rúbia de Aguiar Alencar

Pesquisa-ação sobre sexualidade e vulnerabilidade às IST/aids com alunos de graduação em enfermagem.

Dissertação apresentada à Escola de Enfermagem de Ribeirão Preto da Universidade de São Paulo para obtenção do título de Mestre em Enfermagem Psiquiátrica.

Área de Concentração: Enfermagem Psiquiátrica

Aprovada em:

\section{Banca Examinadora}

$\operatorname{Prof}^{\mathrm{a}} \operatorname{Dr}^{\mathrm{a}}$

Instituição: Assinatura:

Prof $^{a} \operatorname{Dr}^{a}$

Instituição: Assinatura:

$\operatorname{Prof}^{\mathrm{a}} \operatorname{Dr}^{\mathrm{a}}$

Instituição: Assinatura: 


\title{
Dedicatória
}

Dedico este trabalho à Minha Família...

\author{
Meus pais, Osmar Rubens e Vera, \\ responsáveis pelo milagre da minha vida.
}

Agradeço a Deus por ter dado a honra de ser filha de vocês.

Obrigada pelo amor e dedicação que não conhecem fronteira e ultrapassam todos os limites convencionais na busca de um amanhecer melhor a cada dia, proporcionando momentos de felicidades e conquistas únicos.

Obrigada pelas palavras de estímulo e confiança, que ajudaram a me sustentar nesta trajetória. Amo vocês!

\section{Meus irmãos, Melina e Osmar Rubens Filho,} pela atenção e carinho dispensados em todos os momentos. Obrigada por me proporcionarem a felicidade de ser irmã de vocês.

Amo vocês!

Ao meu noivo Leandro,

por todo o seu amor, amizade e companheirismo por me acompanhar desde o primeiro momento em que nos conhecemos.

Obrigada por me fazer acreditar nos nossos sonhos.

Amo muito você... Meu Anjo! 


\section{Agradecimentos}

A Deus, que nos concede, a cada dia, uma página nova no livro do tempo; o que colocamos nele corre por nossa conta. (Emmanuel)

Aos Meus Pais, pelo exemplo de honestidade, determinação e amor.

Ao meu noivo Leandro e Família, por sempre me incentivarem a ir mais longe.

À Prof ${ }^{a}$. Dra. Sônia Maria Villela Bueno, pela dedicação, incentivo e orientação para o desenvolvimento deste trabalho.

Às Prof ${ }^{a}$ s. Dr ${ }^{a}$ s. Isabel Cristina Belasco Bento e Maria Dalva de Barros Carvalho, pelo carinho e pelas valiosas contribuições no Exame de Qualificação e discussão da pro forma.

Ao Departamento de Enfermagem Psiquiátrica, em especial, Adriana Borela Bortoletti Arantes, pela dedicação dispensada durante a trajetória do mestrado.

Aos meus eternos Mestres do Departamento de Enfermagem da Faculdade de Medicina de Botucatu - Unesp, em especial, às Prof ${ }^{a}$ s. Dr ${ }^{a}$ s. Eliana Mara Braga e Vera Lúcia Pamplona Tonete, pelo incentivo, amizade e exemplo de profissionalismo.

Aos alunos da enfermagem, sujeitos da minha pesquisa, que confiaram a mim suas vivências.

Às Faculdades Integradas de Jaú, em especial, à Dra Cleusa Camillo Atique, que desde o primeiro momento acreditou e me incentivou a seguir a vida acadêmica.

À Faculdade Marechal Rondon/UNINOVE, que me proporcionou condições para desenvolver a minha dissertação.

Aos meus alunos, que compartilharam comigo esta fase da minha vida, muito obrigada pelo estímulo e carinho.

Enfim a todos os meus parentes e amigos(as) que sempre me deram força para seguir a diante. 
Quem nunca esteve tão perto de conquistar seu sonho e acabou perdendo?

Quem nunca sentiu uma imensa felicidade ao realizar um sonho? Quem nunca sonhou algo possivel ou impossivel? O que seríamos sem sonhos? Sonho, é tudo aquilo que queremos é tudo aquilo que almejamos é tudo aquilo que parece estar tão longe ... $\mathcal{N}$ o sonho, tudo é permitido, nada pode ter limite, qualquer um pode sonfar... Às vezes o ser humano é tão sonhador, que quando vê conquistado o seu sonho, não the dá o devido valor... outras vezes, passa muito perto do sonho mas nem o reconhece ...

É preciso que estejamos preparados para a realizações de nossos sonhos, para que quando ele estiver em nosso presente, possamos nos sentir satisfeitos com ele.

É preciso que sempre tenhamos sonhos, para a vida ficar mais leve, para estarmos sempre de bem com o mundo, para termos motivos para acordar todos os dias, para que o nosso coração não se sinta vazio, para que o nosso amanhã seja a realidade dos sonhos de hoje ... 


\section{Resumo}

ALENCAR, R. A. Pesquisa-ação sobre sexualidade e vulnerabilidade às IST/aids com alunos de graduação em enfermagem. 2007. 143f. Dissertação (Mestrado). Escola de Enfermagem, Universidade de São Paulo, Ribeirão Preto, 2007.

Nesta pesquisa, trabalhou-se com estudantes da graduação em Enfermagem de uma faculdade pública do interior paulista, propondo: avaliar os fatores de vulnerabilidade para o risco de contaminação às IST/aids (Infecções Sexualmente Transmissíveis), levantar informações gerais sobre o comportamento sexual desses sujeitos, consultar o entendimento dos pesquisados sobre o papel da graduação em relação à temática sexualidade e IST/aids e realizar uma oficina pedagógica à respeito da temática estudada. Para tanto, desenvolveu-se uma pesquisa mediada pela metodologia da pesquisa-ação, fundamentada em referencial teórico-metodológico de Paulo Freire. Coletou-se os dados, mediante questionário individual, com questões norteadoras cujos resultados evidenciaram haver diferenças entre o $1^{\circ}$ e $4^{\circ}$ ano em relação ao comportamento sexual, uso de métodos contraceptivos e opiniões sobre o papel da graduação. Houve entre os indivíduos uma mudança entre o método contraceptivo utilizado na primeira relação sexual (preservativo) e o método escolhido para o relacionamento atual (preservativo associado ao uso do anticoncepcional). O uso sistemático do preservativo ocorre mais entre os alunos do $1^{\circ}$ ano do que entre os do $4^{\circ}$ ano. Para obter conhecimento sobre sexualidade e IST/aids os alunos do último ano sugeriram metodologias de ensino mais participativas (debates, discussões, dinâmicas e oficinas) enquanto os alunos do $1^{\circ}$ ano optaram por metodologias pouco participativas (aulas expositivas e palestras) e participativas. Entre os alunos que estão saindo da faculdade a maioria relata ter obtido informações suficientes, enquanto a maior parte dos alunos do $1^{\circ}$ ano tem expectativa de adquirir mais conhecimento sobre sexualidade e IST/aids. Encontramos que oitenta por cento dos alunos do $4^{\circ}$ ano já haviam vivenciado alguma situação acadêmica onde tiveram que abordar questões sobre sexualidade e/ou IST/aids. Concluímos que a população estudada merece atenção especial por parte de seus educadores, uma vez que, durante toda a nossa pesquisa percebemos a motivação e o interesse em abordar a sexualidade humana e IST/aids. Acreditamos que dessa maneira estaremos formando enfermeiros críticos, autênticos, reflexivos e abertos ao diálogo para discutir a temática em apreço.

Descritores: estudantes, enfermagem, sexualidade, comportamento sexual, educação para saúde 


\section{Abstract}

ALENCAR, R. A. Research-action on sexuality and vulnerability to sexually transmitted diseases/aids with nursing students. 2007. 143f. Master's thesis. School of Nursing, University of São Paulo, Ribeirão Preto, 2007.

In this research we worked with nursing students a public university in the provinces of São Paulo state. We had in mind: to assess the vulnerability factors for the risks of contamination of sexually transmitted diseases (STD)/aids, to obtain general information of those subjects' sexual behavior, to discuss with them their awareness on the role of their course with the topic sexuality and STD/aids and to carry out a pedagogical workshop about that topic. To achieve that, an action-research was conducted based on Paulo Freire's theoretical and methodological references. Data were collected by means of a individual questionnaires having lead questions whose results showed that differences are found between the $1^{\text {st }}$ and $4^{\text {th }}$ year regarding sexual behavior, use of contraceptive methods and opinions about the role of their course. Subjects, who had used a condom in their first sexual intercourse, use a condom associated with contraconceptive bills in their current relationship. The systematic use of a condom occurs more often among $1^{\text {st }}$ year students than among $4^{\text {th }}$ year students. For information about sexuality and STD/aids, last year students suggested having more participative teaching methods (debates, discussions, group work and workshops) whereas $1^{\text {st }}$ year students chose little participative (classes and lectures) and participative methodologies. Most students report having received adequate information whereas most $1^{\text {st }}$ year students expect to acquire more information on sexuality and STD/aids. We found that $80 \%$ of $4^{\text {th }}$ year students had already been in an academic situation in which questions about sexuality and STD/aids were addressed. We concluded that educators need to pay more attention to their students studied since throughout our research we noticed a great deal of motivation and interest in focusing on human sexuality and STD/aids. We believe that we will thus be educating critical, authentic and reflexive nurses willing to discuss this relevant topic.

Descriptors: students, nursing, sexuality, sexual behavior, health education 


\section{Resumen}

ALENCAR, R. A. Investigación-acción sobre sexualidad y vulnerabilidad a enfermedades sexualmente transmisibles/sida con alumnos de graduación en enfermería. 2007. 143f. Tesis de Maestría. Escuela de Enfermería, Universidad de São Paulo, Ribeirão Preto, 2007.

En esta investigación se trabajó con estudiantes de enfermería de una facultad pública del interior de São Paulo y se propuso a: evaluar los factores de vulnerabilidad para el riesgo de contaminación a las infecciones sexualmente transmisibles (IST)/sida, obtener información general sobre el comportamiento sexual de esas personas, consultar el entendimiento de los investigados sobre el papel de la carrera en relación con la temática sexualidad e IST/sida y realizar un taller pedagógico a respecto de la temática estudiada. Para tanto, se desarrolló una investigación mediada por la metodología de la investigación-acción, fundamentada en el referencial teórico-metodológico de Paulo Freire. Se cosecharon los datos, mediante cuestionario individual, con cuestiones guía cuyos resultados evidenciaron haber diferencias entre el $1^{\circ}$ y el $4^{\circ}$ año en relación con el comportamiento sexual, uso de métodos contraceptivos y opiniones sobre el papel de la carrera. Hubo entre los individuos un cambio entre el método contraceptivo utilizado en la primera relación sexual (preservativo) y el método escogido para la relación actual (preservativo asociado al uso del anticoncepcional). El uso sistemático del preservativo ocurre más entre los alumnos del $1^{\circ}$ ano que entre los del $4^{\circ}$ año. Para obtener conocimiento sobre sexualidad e IST/sida los alumnos del último año sugirieron metodologías de enseñanza más participativas (debates, discusiones, dinámicas y talleres) mientras que los alumnos del $1^{\circ}$ año optaron por metodologías poco participativas (clases expositivas y conferencias) y participativas. Entre los alumnos que están saliendo de la facultad la mayoría relata haber obtenido información suficiente, mientras que la mayor parte de los alumnos del $1^{\circ}$ año tienen expectativas de adquirir más información sobre sexualidad e IST/sida. Encontramos que el ochenta por ciento de los alumnos del $4^{\circ}$ año ya había experimentado alguna situación académica en la cual tuvieran que enfocar cuestiones sobre sexualidad e IST/sida. Concluimos que la población estudiada merece atención especial por parte de sus educadores, una vez que, durante toda nuestra investigación nos percatamos de la motivación y el interés en enfocar la sexualidad humana e IST/sida. Creemos que así estaremos formando enfermeros críticos, auténticos, reflexivos y abiertos al diálogo para discutir la temática en aprecio.

Descriptores: estudiantes, enfermería, sexualidad, comportamiento sexual, educación para salud 


\section{Lista de Tabelas}

Tabela 1 - Distribuição numérica e percentual dos alunos de $1^{\circ}$ e $4^{\circ}$ ano em relação ao aspecto sócio-demográfico, segundo faixa etária, sexo, estado civil, religião e com quem mora. 2006.

Tabela 2 - Distribuição numérica e percentual das respostas dos alunos de $1^{\circ}$ e $4^{\circ}$ ano quanto às questões: No momento você está namorando? e Você mantém relacionamentos esporádicos? 2006

Tabela 3 - Distribuição numérica e percentual das respostas dos alunos de $1^{\circ}$ e $4^{\circ}$ ano em relação às questões: Iniciou a vida sexual?, Com quantos anos você teve a $1^{\circ}$ relação sexual e A sua primeira relação sexual foi com quem? 2006

Tabela 4 - Distribuição numérica e percentual das respostas dos alunos de $1^{\circ}$ e $4^{\circ}$ ano, segundo às questões: Você fez uso de algum tipo de método contraceptivo na $1^{\circ}$ relação sexual?, Qual o método contraceptivo usado e Se não usou, por quê? 2006

Tabela 5 - Distribuição numérica e percentual das respostas dos alunos de $1^{\circ}$ e $4^{\circ}$ ano segundo às questões: No seu relacionamento atual você e/ou seu parceiro (a) usam algum tipo de método contraceptivo, Se sim, qual?, Se não usou, por quê? e Onde você adquire esse método contraceptivo? 2006.

Tabela 6 - Distribuição numérica e percentual das respostas dos alunos de $1^{\circ}$ e $4^{\circ}$ ano em relação às questões: Você já deixou de fazer uso da camisinha em alguma relação sexual?, Se sim, por que? e Se não usou, por que? 2006.

Tabela 7 - Distribuição numérica e percentual das respostas dos de $1^{\circ}$ e $4^{\circ}$ ano segundo à questão: Quantos parceiros (as) sexuais você teve neste último ano? 2006.

Tabela 8 - Distribuição numérica e percentual das respostas dos alunos de $1^{\circ}$ e $4^{\circ}$ ano em relação à questão: Você já adquiriu algum tipo de IST (Infecções Sexualmente Transmissíveis)? 2006.

Tabela 9 - Distribuição numérica e percentual das respostas dos alunos de $1^{\circ}$ e $4^{\circ}$ ano em relação à questão: Classifique o grau de risco em adquirir alguma IST em cada tipo de relação sexual (sexo vaginal, oral, anal e com preservativo)? 2006

Tabela 10 - Distribuição numérica das respostas dos alunos de $1^{\circ}$ e $4^{\circ}$ ano, em relação à questão: Durante sua vida como foi que você adquiriu informações sobre sexualidade e às IST? 2006 
Tabela 11 - Distribuição numérica e percentual das respostas dos alunos de $1^{\circ}$ e $4^{\circ}$ ano, em relação à questão: Antes de você ingressar na faculdade qual era o seu grau de conhecimento sobre a prevenção das IST/aids? 2006.

Tabela 12 - Distribuição das respostas dos alunos do $4^{\circ}$ ano, em relação à pergunta: Em qual (ais) disciplina (as) você teve contato com o tema sexualidade e IST/aids? 2006

Tabela 13 - Distribuição das respostas de 30 indivíduos, do $4^{\circ}$ ano em relação à pergunta: Você já passou por alguma situação durante a graduação em enfermagem (p. ex: estágios) em que você teve que ter conhecimento sobre o tema sexualidade/IST/aids? 2006

Tabela 14 - Distribuição numérica e percentual das respostas dos alunos do $1^{\circ}$ e $4^{\circ}$ ano da graduação em enfermagem, em relação à pergunta: Você gostaria de participar de uma oficina de trabalho, onde estaremos desenvolvendo atividades educativas sobre sexualidade humana e IST/aids? 2006 


\section{Lista de Quadros}

Quadro 1 - Distribuição das respostas dos 29 alunos do $1^{\circ}$ ano de graduação em enfermagem, em relação à pergunta: Como você analisa o seu comportamento sexual em relação ao risco de você adquirir alguma IST? 2006.

Quadro 2 - Distribuição das respostas dos 30 alunos do $4^{\circ}$ ano de graduação em enfermagem, em relação à pergunta: Como você analisa o seu comportamento sexual em relação ao risco de você adquirir alguma IST? 2006

Quadro 3 - Distribuição das respostas de 29 indivíduos do $\mathbf{1}^{\circ}$ ano da graduação em enfermagem, em relação à pergunta: $O$ que você espera que a graduação em enfermagem lhe ofereça de conhecimento sobre a temática sexualidade e IST/aids? 2006

Quadro 4 - Distribuição das respostas de 29 alunos do $1^{\circ}$ ano da graduação em enfermagem em relação à pergunta: Como você acha que seria a melhor maneira de aprender sobre o tema sexualidade humana, IST/aids durante a graduação em enfermagem? 2006

Quadro 5 - Distribuição das respostas de 30 alunos, do $4^{\circ}$ ano, em relação à pergunta: Como você acha que seria a melhor maneira de aprender sobre o tema sexualidade humana, IST/aids durante a graduação em enfermagem? 2006

Quadro 6 - Distribuição das respostas de 30 alunos do $4^{\circ}$ ano da graduação em enfermagem em relação à pergunta: Você acredita que o que a graduação em enfermagem lhe oferece de informações sobre sexualidade humana e as IST/aids, é o suficiente para que você possa desenvolver o seu trabalho como enfermeiro quando sair da faculdade? Por quê? 2006

Quadro 7 - Distribuição das respostas de 30 alunos, do $4^{\circ}$ ano, em relação à pergunta: Além do conhecimento sobre sexualidade humana e IST/aids que a graduação em enfermagem já ofereceu para você, o que mais você acredita que a graduação em enfermagem poderia fornecer para que você pudesse atuar com mais "segurança" em relação à sexualidade humana e IST/aids diante dos seus futuros pacientes? Apresente sugestões. 2006 98

Quadro 8 - Distribuição das respostas dos alunos do $4^{\circ}$ ano em relação à questão: Descreva rapidamente uma situação vivida por você onde você teve que ter conhecimento sobre o tema sexualidade/IST/aids. 2006.

Quadro 9 - Distribuição das respostas dos alunos do $4^{\circ}$ ano em relação à questão: Qual é ou foi o sentimento que você teve ao ter que abordar o tema sexualidade/IST/aids com um paciente? 2006

Quadro 10 - Distribuição das expressões dos alunos de $1^{\circ}$ e $4^{\circ}$ ano, em relação ao espaço oferecido aos alunos para expressar o que quisessem. 2006 


\section{Sumário}

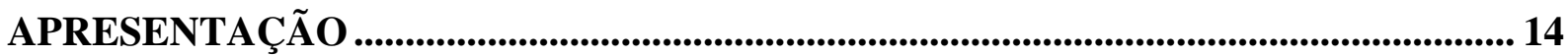

1 INTRODUÇÃO ............................................................................................................... 17

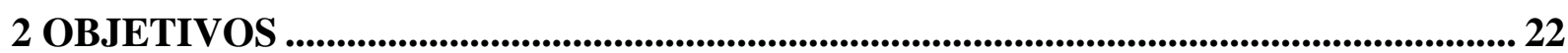

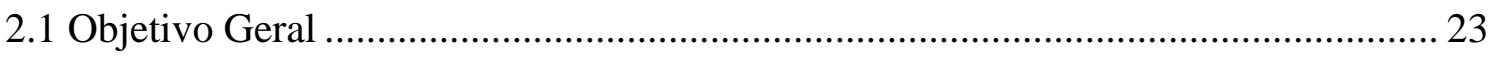

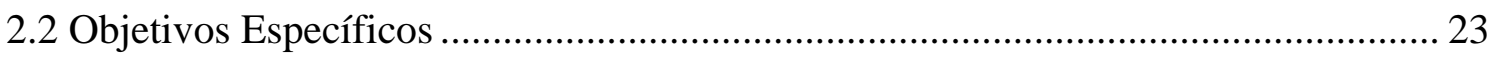

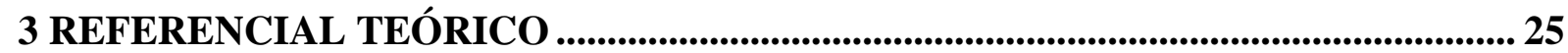

3.1 Educação para Sexualidade ................................................................................ 26

3.2 A Enfermagem Trabalhando com a Temática da Sexualidade e IST/Aids ................ 30

3.3 Referencial teórico-metodológico ………………………………………………..... 37

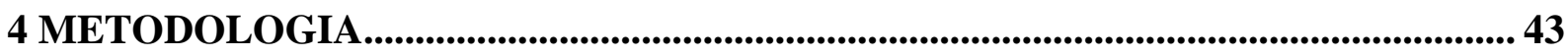

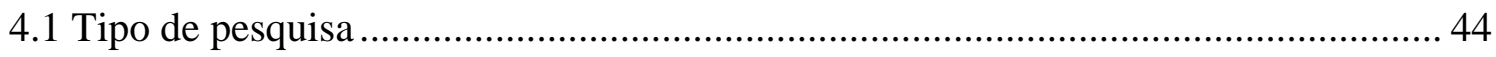

4.2 Local da Pesquisa ................................................................................................ 45

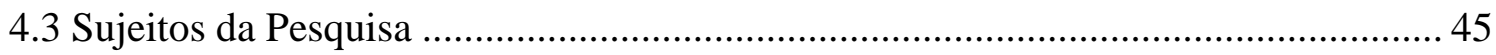

4.4 Critérios para inclusão dos sujeitos à pesquisa........................................................... 46

4.5 Procedimentos para Coleta e Análise de Dados ……………………………………... 46

4.6 Procedimento para a Realização da Pesquisa ............................................................. 47

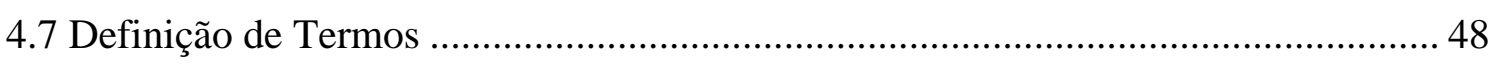

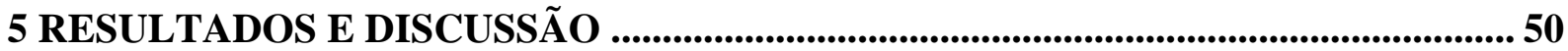

$1^{\circ}$ Etapa - Caracterização dos sujeitos participantes da pesquisa...................................... 52

$2^{\circ}$ Etapa - Questões sobre a temática da pesquisa propriamente dita................................. 53

$3^{\circ}$ Etapa - Ações/intervenções educativas do processo a ser realizado na oficina

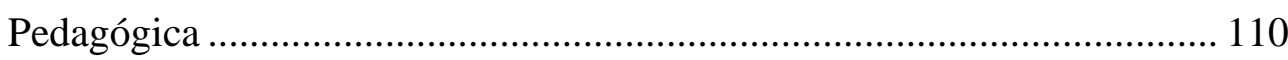

6 CONSIDERAÇÕES FINAIS............................................................................................ 125

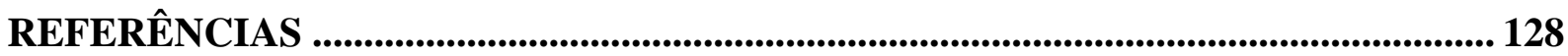

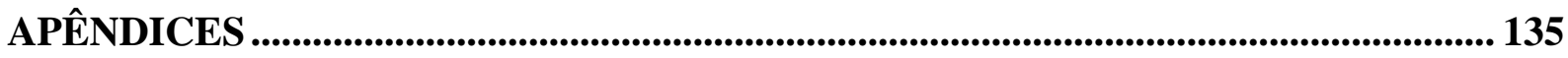

ANEXOS 
APRESENTAÇÃO 
Durante a nossa Graduação em Enfermagem, o interesse em estudar mais profundamente a temática da sexualidade e IST/aids ${ }^{1}$ ocorreu após o estágio extracurricular, no Ambulatório Especial de Moléstias Infecto-contagiosas, especificamente no atendimento a pacientes portadores do HIV, ocasião em que pudemos vivenciar a experiência, juntamente com pacientes em estado constante de angústia, tristeza, perda e decepção por serem portadores de uma doença ainda sem cura, a aids.

A partir desta oportunidade, começamos a refletir sobre a importância da Educação em Saúde para a população e, desde então, o interesse sobre sexualidade e IST/aids foi emergindo durante o desenvolvimento dos nossos trabalhos científicos; neste investimento, a educação preventiva foi a base fundamental destes estudos.

Atualmente trabalhando como professora universitária, notamos o quanto é incipiente a abordagem sobre a temática sexualidade e IST/aids dentro da universidade, e, caso não haja o tratamento do tema, pode haver lacunas em nossa formação. Na Graduação em Enfermagem, o enfoque sobre as IST é apresentado na disciplina de Moléstias infectocontagiosas, na qual os alunos estudam a patologia, manifestação clínica e os cuidados de enfermagem. Um fato que temos observado durante as nossas aulas é o interesse dos alunos em saber como lidar com a sua própria sexualidade e com a sexualidade dos pacientes.

Mediante tais percepções, observamos que o educador enfermeiro necessita desses atributos específicos para garantir a sua competência ao lidar com esta temática no meio universitário e, portanto, profissional.

Não obstante, o enfermeiro é o profissional que tem oportunidade de prestar assistência aos mais variados grupos de pessoas - criança, adolescente, adulto e idoso. Independentemente do sexo, raça, nível sócio-econômico e cultural, o indivíduo deve ser visto como um todo (GIR; NOGUEIRA; PELÁ, 2000; BUENO, 2001). Depreendemos assim que

\footnotetext{
${ }^{1}$ A Organização Mundial da Saúde recomenda que o termo Doenças Sexualmente Transmissíveis (DST) seja substituído pelo termo Infecções Sexualmente Transmissíveis (IST), por melhor incorporar as infecções assintomáticas (WHO, 2001).
} 
sexualidade é parte intrínseca do ser humano e que está presente em todas as etapas do ciclo da vida.

Neste sentido, Gir, Nogueira e Pelá (2000) afirmam que, para o enfermeiro desenvolver uma abordagem concernente ao assunto, é necessário que ele tenha um embasamento suficiente a sexualidade, nas diferentes fases da vida.

Para tanto, buscamos, no Programa de Pós-Graduação, maior embasamento quanto à temática que propomos desenvolver na nossa dissertação de mestrado, bem como na participação nas disciplinas cursadas durante este período e nas reflexões com nossa orientadora para solidificar esses conhecimentos, o que nos possibilitou a efetivação do presente estudo. 
INTRODUÇÃO 
A sexualidade humana tem sido trabalhada, desde épocas mais remotas, de forma oculta, conforme nos é evidenciado na literatura, ao resgatarmos a sua história.

Isso acontece como conseqüência dos medos, preconceitos e tabus, que sempre acompanharam a questão da sexualidade humana. Esses elementos têm sido associados aos mitos e crendices populares, que, em seu conjunto, acabaram influenciando consideravelmente o povo, emperrando esse conhecimento e retardando o surgimento da Educação Sexual, área de conhecimento ainda recente. Isto certamente dificultou o acesso às orientações relativas ao sexo e aos assuntos correlatos, bem como ao conhecimento científico, neste sentido prejudicando a saúde pública nacional, sobremaneira a saúde sexual e reprodutiva, tanto em âmbito pessoal quanto coletivo (BUENO; COSTA; BORELLI, 1995).

A sexualidade, entendida a partir de um enfoque abrangente e humanista, manifesta-se em todas as fases da vida de um ser humano e, ao contrário da conceituação vulgar, tem na genitalidade apenas um de seus aspectos, talvez nem mesmo o mais importante. Dentro de um contexto mais amplo, pode-se considerar que a influência da sexualidade permeia todas as manifestações humanas, desde o nascimento até a morte (VITIELLO, 1997).

No entanto, durante a maior parte da história da humanidade, a influência da sexualidade foi negada, em especial entre os povos ligados às tradições judaicas e cristãs (BUENO, 2001).

Vitiello (1997) acredita que a interpretação cívica da Bíblia, há tantos séculos, vem influenciando a nossa cultura, considerando o sexo como um mal necessário, admissível, apenas por ser indispensável à reprodução da espécie humana. Inaugurou-se, a partir dessa interpretação, a confusão entre sexualidade e genitalidade, perdurando até os dias atuais.

Ramadam e Abdo (2001) referem que as religiões são, quase todas, ambíguas: prescrevem a procriação, mas o seu principal instrumento, a sexualidade, é proscrita nas suas manifestações mais espontâneas. 
Embora nossa civilização tenha, nos últimos séculos, vivido alguns momentos de maior liberdade, essa visão distorcida da sexualidade foi a tônica principal, mantida durante todos esses séculos em que ela se cristalizou.

Em relação à sexualidade Muraro (1985) revela uma problemática voltada à questão da mulher. Para a autora a explosão populacional mundial e a sexualidade são mais importantes que todos os sistemas econômicos. Eles não rompem essa relação familiar que cria as classes, que cria as hierarquias, e, realmente, não toca no ponto básico que é: a mulher radicalmente excluída dos dois sistemas econômicos.

Muraro apud Bento (2000) ressalta que na área da sexualidade feminina, os preconceitos e a desinformação, têm causado graves conseqüências para a saúde sexual.

A sexualidade humana mesmo em seus momentos de maior liberdade, o exercício pleno da sexualidade sempre foi apanágio das pessoas adultas, que vêem, com maus olhos, a sexualidade dos adolescentes, ridicularizando as manifestações sexuais da terceira idade e negam - ao menos negaram até poucas décadas - a sexualidade na infância (VITIELLO, 1997).

Sabemos que a sexualidade é inerente ao ser humano. Nós, como profissionais da saúde e sobretudo educadoras, deparamo-nos no nosso dia a dia com diversas situações relativas à sexualidade e às IST/aids, o que exigem de nós o conhecimento sobre esta temática. Isto por si instiga-nos a entender a necessidade emergencial do preparo efetivo do enfermeiro para lidar adequadamente com estas questões no seu cotidiano profissional.

Não obstante, podemos verificar que nem sempre alguns docentes enfermeiros estão aptos a atenderem problemas relacionados a esses temas. Isto pode ser constatado pela pesquisa realizada por Miyasaki e Bueno (2001), quando afirmam que os professores pesquisados por elas referiram ter ciência dos problemas decorrentes das IST/aids, revelando terem dificuldades a lidar com isto. Todavia, há consenso entre eles sobre a necessidade de serem mais bem preparados para trabalhar com questões relativas à sexualidade e IST/aids. 
Por vezes, nos dias atuais, podemos notar as grandes mudanças ocorridas no contexto da sexualidade, principalmente dos jovens. Freqüentemente deparamo-nos com adolescentes que, de certa forma, segundo Miyasaki e Bueno (2001), se dizem traumatizados por terem se iniciado tão cedo na prática sexual, sem informações suficientes para evitar as IST ou até mesmo assumir uma gravidez precoce ou não planejada.

Outro dado que nos deixa em alerta é o aumento do número de pessoas infectadas por algum tipo de IST. Segundo a Organização Mundial de Saúde (2004), ocorrem no Brasil cerca de 12 milhões de IST ao ano. O número de casos notificados fica muito abaixo da estimativa da OMS, ou seja, cerca de 200 mil casos/ano.

Devemos nos atentar também para a incidência de gravidez na adolescência. Podemos notar o quanto esse contingente populacional está vulnerável, uma vez que o elevado número de garotas grávidas nos indica o quanto os jovens estão expostos também a adquirir algum tipo de infecção sexualmente transmissível.

No Brasil, observa-se que, apesar do declínio das taxas de fecundidade desde o início dos anos 70, é cada vez maior a proporção de partos entre as adolescentes em comparação com o total de partos realizados no País. Segundo dados estatísticos do SUS relativos ao ano 2000, dos 2,5 milhões de partos realizados nos hospitais públicos do país, 689 mil eram de mães adolescentes com menos de 19 anos de idade (DADOORIAN, 2003). Esses fatos mostram a necessidade de repensarmos em como diminuir esses índices, onde atuarmos e de que forma fazê-los. Assim, acreditamos que o caminho passa ser pela educação sexual, que é necessária e fundamental.

Ao refletirmos sobre o processo educativo, Vitiello (1995) afirma que educar significa formar alguém, proporcionando condições para que esse cresça, não se tornando cópia do educador, mas uma pessoa consciente e responsável pelos seus atos. Essa educação deve ser intensa e contínua. Sendo assim, a educação sexual sistemática só pode ser feita por familiares 
e/ou professores preparados, pois apenas a família e a escola, como instituição social, conseguem atuar de maneira contínua e duradoura.

Para que se consolide, é preciso ter conhecimentos e habilidades para se chegar à conscientização. Dessa maneira, se processa a educação (BUENO, 2001).

Para Freire (1996; 2000), o ser humano é histórico, está submerso em condições espaço-temporais e, quanto mais refletir de maneira crítica sobre sua existência, mais poderá influenciar-se e tornar-se mais livre.

Diante do exposto e devido à vulnerabilidade e à suscetibilidade dos jovens, aos riscos de contaminação às IST/aids, entre outros problemas decorrentes da própria sexualidade, entendemos ser de fundamental importância o investimento educativo e científico nesta área, bem como a necessidade de implantação e implementação de ações que visem orientação, informação e esclarecimento que forneçam o desenvolvimento de habilidades para o exercício de uma sexualidade mais consciente, segura e responsável.

Precisamos compreender a importância da Educação Sexual, aprofundando e instrumentalizando-nos para lidarmos com as eventuais dificuldades no nosso cotidiano profissional. Acreditamos que seja necessário ampliar a visão do sexo e da sexualidade no contexto contemporâneo, transferindo os valores negativos, como o pecado e o proibido, para aqueles que se relacionam aos valores atrelados ao respeito, segurança e responsabilidade, para que isso venha a favorecer o exercício de uma sexualidade plena, considerando também neste intento a questão de gênero.

Isto posto, estamos trabalhando a temática de forma ética e segura, procurando incentivar os sujeitos para a mudança de comportamento, com vistas à busca de uma saúde integral e particularmente a uma efetiva e positiva saúde sexual, para a garantia da otimização da vida e do exercício pleno da cidadania. 
OBJETIVOS

$\overline{-(2000}$ 
Levando em consideração o comportamento de risco frente à sexualidade e às IST/aids de jovens acadêmicos, propusemo-nos a traçar os objetivos que se seguem.

\section{Objetivo}

\subsection{Objetivo Geral}

Avaliar os fatores de vulnerabilidade entre os acadêmicos de $1^{\circ}$ e $4^{\circ}$ ano de um Curso de Graduação em Enfermagem para o risco de contaminação às IST/aids, do comprometimento da sua sexualidade, levantando necessidades e buscando, conjuntamente, meios de aprimorar o seu conhecimento sobre a temática em apreço, tendo em vista a sua vida pessoal e profissional.

Isto levou-nos a especificar os seguintes objetivos:

\subsection{Objetivos Específicos}

- Identificar os dados sócio-demográficos dos sujeitos da pesquisa;

- Levantar informações gerais sobre o comportamento sexual do aluno quanto aos riscos de aquisição das IST/aids em relação aos métodos contraceptivos, destacando os preservativos masculino e feminino;

- Verificar o conhecimento sobre sexualidade e a prevenção das IST/aids antes do ingresso na faculdade;

- Consultar qual o seu entendimento sobre o papel da graduação de enfermagem em relação à temática sexualidade e IST/aids, comparando o conhecimento dos alunos do $1^{\circ}$ com os do $4^{\circ}$ ano;

- Identificar entre os alunos do $4^{\circ}$ ano de graduação em enfermagem a vivência do tema sexualidade durante suas atividades acadêmicas; 
- Realizar junto aos universitários uma oficina pedagógica a respeito de questões sobre sexualidade, práticas sexuais de risco e às IST/aids.

- Verificar conjuntamente (educando/pesquisando e educador/pesquisador) os conhecimentos e habilidades sobre o assunto, sensibilizando-os para hábitos e atitudes seguros relacionados ao sexo ativo, visando a prepará-los para serem agentes multiplicadores desse saber. 
REFERENCIAL TEÓRICO 


\subsection{Educação para Sexualidade e IST/Aids}

As questões das IST/aids apresentam-se como desafio para todas as pessoas que se preocupam com o futuro da humanidade.

Nos dias atuais, é impossível negar as mudanças que acontecem em nossa sociedade. Estamos vivenciando momentos de crise em relação aos valores éticos e morais, políticos e econômicos. Talvez esta situação seja resultado do processo acelerado de troca de informação por todo o planeta, pela evolução tecnológica ou pelo próprio processo de urbanização desenfreado (MIYASAKI; BUENO, 2001).

Em meio a tantas mudanças, o que passamos a destacar com grande relevância são aquelas ocorridas no contexto da sexualidade, principalmente dos jovens.

Percebemos, então, que apesar de todo o investimento feito em campanhas educativas relacionadas à vida sexual saudável e as IST/aids, essas doenças continuam crescendo e invadindo casas, famílias, desmistificando a idéia de doença do outro. Cai, portanto, a cortina da rígida moral social e a sexualidade passa a ser desvendada na busca de compreensão do comportamento humano, para que possamos exercê-la de forma responsável, saudável, sem riscos de contrair o HIV, entre outras IST (NASCIMENTO, 2003).

É preciso, sobremaneira, compreender o comportamento humano e a própria vida dentro de uma perspectiva que vislumbre a visão totalizadora do ser, de forma contextualizada, considerando a necessidade fundamental da valorização da qualidade de vida e o exercício pleno de cidadania. É importante, pois, despertar no indivíduo a consciência crítica e reflexiva para o avanço e para as mudanças, visando à transformação e tendo em vista a otimização dessa realidade, promovendo ainda, o auto cuidado e a aspiração para o significado de uma vida plena, a busca do exercício da cidadania, tal como preconiza a Organização Mundial da Saúde (WHO, 1993; BUENO, 2001). 
Para que todo ser humano possa viver com dignidade e de forma plena e positiva, é de fundamental importância o acesso à Educação e à Saúde. A Educação, portanto, não deve ser considerada apenas como um processo cultural, mas sim como algo que deve ser compreendido dentro de um referencial histórico mais amplo. Ela é a base sobre a qual se sustentam o indivíduo e a sociedade. Sem ela, a vida retornaria ao estado primitivo, sem que se pudessem definir os valores éticos, sociais e morais do indivíduo e do grupo social no qual se movimenta. Nos séculos XIX e XX, surgiram os autores que muito enriqueceram a Educação, como Comte, Pavlov, entre outros, além de ricas contribuições advindas de Pestalozzi, Piaget, Vygotsky, Anísio Teixeira, Paulo Freire, que alargaram as possibilidades de entendimento, em favor do educando e do próprio educador (BUENO, 2001).

Sendo assim, todo ser humano tem direito à Educação, mas, sobretudo, as crianças, os adolescentes e os jovens, visando ao pleno desenvolvimento das pessoas.

As questões da sexualidade, do sexo e das IST/aids merecem cuidados especiais. Neste sentido, a Lei - 8642/93 é que estabelece a execução do Programa Nacional de Atenção Integral à Criança e ao Adolescente (PRONAICA), que promove e coordena o desenvolvimento de ações de atenção integral ao contingente infantil e juvenil. Na comunidade escolar, os procedimentos em relação ao HIV/Aids/DST são normatizados pela Portaria Interministerial MEC/MS - 796, 29/05/92, e é o aviso ministerial n 376/6m, 20/04/94 que pede a introdução do assunto DST/Aids, obrigatoriamente, no currículo do ensino básico nacional (BRASIL, 1995; BUENO, 2001).

Podemos notar que a educação sexual no Brasil apresenta avanços e retrocessos na sua história. Já na década de 20, o assunto era reivindicada por alguns segmentos da sociedade, destacando-se o grupo de feministas da Federação Brasileira pelo Progresso Feminino. Também alguns médicos e higienistas apregoavam a necessidade da educação sexual, mas 
estes limitavam seus objetivos ao combate à masturbação e às doenças venéreas e como preparo da mulher para o papel de mãe e esposa (BARROSO; BRUSCHINI, 1982).

Os autores acima nos contam que, em 1930, no Colégio Batista do Rio de Janeiro, foi incluído no currículo, por iniciativa do professor Stawiarski, o ensino da evolução das espécies e da educação sexual. Apesar de o curso ter transcorrido em um clima de prudência e austeridade, o professor foi processado e demitido pela acusação de comportamento imoral.

Atualmente em nosso meio os termos educação sexual e orientação sexual são utilizados como sinônimos. À guisa de uma melhor compressão buscamos na literatura autores que se aproximassem desta temática.

Segundo Pissato (1981) e Jesus (2000), a orientação sexual é aquela que faz parte do processo educativo em que os conhecimentos e experiências sobre as questões sexuais são fornecidas às pessoas de modo intencional e formal. Se esta orientação se tornar contínua e duradoura, poderá constituir-se parte da educação sexual.

Independentemente da palavra utilizada, orientação ou educação, o que importa é a postura adquirida pelo educador, ou seja, visualizar o educando como sujeito, livre para pensar, sentir e agir durante as ações educativas.

Nos últimos tempos, a Educação para sexualidade começou a tomar rumo e se reportar a uma concepção mais ampla de Educação para a plenitude do exercício adequado da sexualidade humana.

Seguindo o pensamento de Pissato (1981) e Jesus (2000), adotaremos o termo educação sexual ao longo deste estudo.

Bueno (2001) ressalta que a Educação Sexual, nos tempos de HIV/Aids, tem função extremamente relevante na prevenção do vírus e da doença. Hoje, mais do que nunca, ela deverá voltar-se também para os problemas relacionados à sexualidade e ao sexo seguro, como forma de promoção da saúde sexual, já que essas dificuldades comprometem 
severamente a saúde integral e, conseqüentemente, a saúde sexual das pessoas, podendo afetar tanto o indivíduo particularmente quanto o seu próprio grupo e, portanto, a coletividade.

Por outro lado, é importante lembrar que a educação sexual não encoraja os jovens a terem relações sexuais, mas os ajuda a exercer a sua sexualidade com prazer e responsabilidade, evitando gravidez precoce ou não planejada, IST/aids e adotando práticas seguras, com respeito, segurança e responsabilidade (BRASIL, 1995).

Assim, a Educação para a Saúde assume medida de destaque, uma vez que se trata de instrumento básico para a informação e conscientização das pessoas. Desta forma, a orientação de medidas mais adequadas em saúde junto à população é considerada uma das maneiras mais efetivas para reduzir a disseminação das IST/aids.

Nesta perspectiva, a identificação prévia dos conhecimentos de IST/aids e de medidas preventivas acerca destas doenças são importantes para o desenvolvimento de um programa educativo específico.

Sendo assim, para cada população específica é necessária a elaboração de uma proposta de modelo educacional, baseado em seus saberes, práticas e necessidades reais sobre sexualidade, práticas sexuais seguras, IST/aids e drogas, entre outras questões relacionadas. Estas propostas devem fornecer espaço e voz para que as pessoas possam, ao mesmo tempo, realizar o exercício do seu próprio discurso e de sua história, expressar sentimento e experiências vividas, buscando ainda reflexões de sua ligação com o HIV/IST/aids (WARWICK; KIPPAX, 1990; AGGLENTON, 1992; WHO, 1999).

Para Bueno (2001), todos os processos educativos, assim como suas respectivas metodologias e meios, têm por base uma determinada pedagogia, isto é, uma concepção de como se consegue que as pessoas aprendam alguma coisa e, a partir daí, modifiquem seu comportamento. Neste sentido, optamos em trabalhar a modalidade de investigação, a pesquisa-ação, pois nos permite identificar problemas com os sujeitos 
pesquisados, buscando, certamente, por meio das ações e intervenções educativas, possíveis soluções às dificuldades encontradas.

\subsection{A Enfermagem Trabalhando com as Temáticas da Sexualidade e IST/Aids}

Discutir sexualidade humana tem sido considerado um tema difícil, geralmente entendido como algo ligado a tabu, pecado, proibido, portanto, um assunto pouco abordado até mesmo entre os adultos.

Porém podemos notar, por meio de uma revisão da literatura, o grande crescimento das pesquisas científicas relacionadas à sexualidade humana, como, por exemplo, os estudos desbravadores de Henry H. Ellis (1859-1939), Sigmund Freud (1856-1936), Michel Focault (1926-1984), os quais, certamente, tiveram que enfrentar algumas dificuldades, como censura e críticas no momento de apresentar seus investimentos nesta área, retratando as questões da sexualidade.

Mas, mesmo diante de todo este avanço científico e tecnológico das últimas décadas, podemos observar que a sexualidade ainda é um tema que carrega consigo muito preconceito, falta de conhecimento por parte de muitas pessoas, assim como visto, algo banalizado.

Assim, a abordagem da sexualidade tem sido realizada de diferentes maneiras pela nossa sociedade.

Domingues (1997) ressalta que os meios de comunicação acabam por divulgarem de forma abusiva a sexualidade, enquanto na área da saúde se fixa a atenção na reprodução e nos riscos de contaminação e transmissão das IST.

Já a escola possui grande responsabilidade no que diz respeito à educação sexual.

Diante da grande importância do papel da escola, Bueno (2001) elaborou um documento para o Ministério da Saúde orientando as amplas questões que se atrelam à 
sexualidade e IST/aids, direcionando ações preventivas voltadas para as crianças, os adolescentes e os adultos jovens. Este documento foi resultado dos investimentos de seus estudos desenvolvidos na Escola de Enfermagem de Ribeirão Preto - Universidade de São Paulo (EERP-USP), em que delegados de ensino, diretores de escolas e professores receberam capacitação nesta área, preparando-os para lidar com as temáticas: sexualidade, sexo seguro e as IST/aids no ambiente escolar.

No entanto, encontramos na literatura que os professores da rede escolar enfrentam grandes desafios em atuar nesse contexto, começando pelo desconhecimento da sua própria sexualidade e com isso tendo que se confrontar com certas dificuldades em trabalhar com essa temática em sala de aula, no cotidiano escolar (TIBA, 1994; OLIVEIRA; BUENO, 1997).

Ressaltamos que as dificuldades encontradas pelos professores da rede escolar se estendem aos professores universitários, em particular do curso de graduação em enfermagem, tal como nos mostram as autoras Miyasaki e Bueno (2001) e Ramin e Soler (2002).

Miyasaki e Bueno (2001) pesquisaram o conhecimento dos professores de enfermagem de uma faculdade pública do interior paulista e perceberam que aqueles docentes apresentavam dificuldades em lidar com a temática sexualidade, inclusive, eles mesmos acreditavam que deveriam ser mais bem preparados para trabalhar a sexualidade com o aluno da graduação em enfermagem.

Em seus estudos, Ramin e Soler (2002) concluiram que os professores não têm consciência de que são superficiais e pouco reflexivos na abordagem da sexualidade e que os docentes da enfermagem acabam por oferecer informações superficiais sobre sexualidade, dando ênfase maior aos aspectos anatomo-fisiológicos, apresentando uma visão biologicista e fragmentada da sexualidade, em vez de aborda-la dentro de uma perspectiva totalizadora, com incorporação do aspecto biopsíquico, social e espiritual da questão da sexualidade humana. 
Há mais de uma década, autores como Garcia (1993) já questionavam se a dimensão da sexualidade e do ser humano estava sendo considerada durante o planejamento da assistência de enfermagem.

Notamos que os trabalhos têm enfatizado que o ser humano não pode ser entendido nem pode funcionar exceto em sua totalidade, como um ser com qualidades físicas, mentais, emocionais, sociais e espirituais (GARCIA, 1993; PELÁ et al., 1995; GIR, NOGUEIRA; PELÁ, 2000).

Por meio da revisão literária, notamos que o profissional enfermeiro tem se preocupado em trabalhar os temas sexualidade e IST/Aids com diversos grupos da nossa sociedade.

Pelá et al. (1995) trabalharam a questão da sexualidade humana no contexto da assistência de enfermagem. A autora estudou 149 enfermeiros de Hospital Escola e, após a análise dos dados, concluiu que estes profissionais carecem de informações na área da sexualidade humana, dificultando sua vivência profissional. Ressaltaram ainda que esses enfermeiros estudados apresentam dificuldades de refletir sobre a sua própria sexualidade.

Oliveira (1997) trabalhou em seu mestrado com a comunicação educativa do enfermeiro na promoção da saúde sexual entre os escolares de $1^{\circ}$ e $2^{\circ}$ graus. A autora evidenciou que não houve grandes discrepâncias entre as opiniões dos escolares de $1^{\circ}$ e $2^{\circ}$ graus (atual Ensino Fundamental e Médio), quer em relação aos conhecimentos relativos às DST, quer quanto à Aids, revelando dificuldades semelhantes, o que justifica a necessidade de ações e intervenções educativas nesta área.

Nascimento (1997), em um estudo exploratório, buscou detectar a atitude dos caminhoneiros de estrada frente à Aids. Trabalhou com 200 caminhoneiros e concluiu que esta categoria de trabalhadores necessita de campanhas informativas e educativas para melhorar o nível cognitivo-afetivo-comportamental em algumas questões relativas à Aids. A 
autora sugere outras pesquisas investigando o comportamento sexual e o estilo de vida dos caminhoneiros.

Giordani (2000) desenvolveu em seu mestrado uma pesquisa-ação com 49 mulheres detentas de três cadeias públicas femininas do interior paulista, objetivando levantar com elas seus problemas frente à sexualidade, DST, aids e drogas, trabalhando, a seguir, um programa educativo sobre estes temas, possibilitando-lhes conhecimentos e habilidades nesta área, bem como preparando-as para serem agentes multiplicadores. Ao final da pesquisa, a autora concluiu que essas mulheres sentem profunda tristeza pela situação em que se encontram, sendo que a maioria estava presa devido ao tráfico de drogas. Verificou ainda que elas praticam qualquer tipo de sexo, mas preferem o vaginal; são promíscuas e algumas bissexuais. Sobretudo, possuem grande interesse em saber e participar de atividades educativas no interior das cadeias sobre estas temáticas.

Bento (2000), em sua dissertação de mestrado, trabalhou com acadêmicos de uma universidade pública do interior paulista, quando levantou junto a esses sujeitos suas práticas sexuais entre eles, sua opinião a respeito da prostituição e homossexualismo, a incidência de DST e abuso sexual, a aderência ao uso de preservativos como meio de proteção às DST e Aids. A autora concluiu que os universitários têm uma vida sexual ativa, uma aderência relativa ao preservativo, um índice baixo de DST e abuso sexual, e muita dificuldade e dúvidas referentes à temática. Ao final, a autora desenvolveu um programa educativo participativo para contemplar ações voltadas à mudança de comportamento com vistas ao desenvolvimento de uma prática sexual com maior responsabilidade.

Bueno (2001) apresenta resultados de um estudo de 20 anos sobre educação preventiva em Sexualidade e IST/Aids, drogas e violência nas escolas, trabalhando com os diretores regionais de ensino, coordenadores, supervisores, professores, entre outros, revelando achados significantes nas escolas. Tem trabalhado também com creches, caminhoneiros, militares, 
profissionais do sexo, meninos de rua, mulheres em detenção, universitários, idosos, adultos jovens, adolescentes e crianças, enfocando as questões da sexualidade e sua relação com a Aids.

No seu doutorado, Giordani (2003) trabalhou a questão da violência voltada à mulher, em especial à mulher detenta. Os resultados evidenciaram que a violência sexual é repudiada e tida como geradora de marcas psíquicas e emocionais à mulher. Sentimentos de rejeição, humilhação, revolta, baixa auto-estima e medo, foram descritos pela maioria delas. A autora conclui que são necessárias ações educativas voltadas à violência de gênero e às temáticas interligadas a essa questão, merecendo que sejam implantados programas especiais educativos, exames e controle da saúde sexual e reprodutiva da mulher detenta, sob a supervisão de profissionais de saúde gabaritados.

Nascimento (2003) em seu doutorado investigou os fatores de vulnerabilidade entre os caminhoneiros de estrada para o risco de contaminação com HIV/Aids. Os resultados encontrados apontam que os caminhoneiros têm conhecimentos sobre vários aspectos da transmissão da Aids, mas muitos se envolvem em relacionamentos sexuais na estrada sem o uso do preservativo. O uso de álcool e anfetaminas constitui fatores de vulnerabilidade, uma vez que, sob efeito da bebida, nos pontos de paradas para descanso, alguns se envolvem com prostitutas. Ao final, a autora ressalta que os comportamentos observados pelos caminhoneiros estão fundamentados em princípios socialmente construídos com base na cultura machista, levando muitos a se envolverem no sexo sem proteção ou em aventuras como forma de mostrar sua virilidade.

Galvão et al. (2003) buscaram avaliar o conhecimento sobre sexualidade e IST/Aids em uma população do interior nordestino e propor ações para educação em saúde. Estudaram 15 homens e 54 mulheres, com idades entre 18 e 75 anos. Encontraram que entre as mulheres a primeira relação sexual ocorreu entre 16 e 19 anos, e com os homens entre 13 e 15 anos; as 
primeiras informações sobre sexo foram dadas por profissionais da saúde; o método contraceptivo mais usado era anticoncepcional oral, seguido pelo preservativo masculino; e a maioria dos entrevistados apontava formas corretas de transmissão de IST/aids. Concluiram que a população estudada tem conhecimentos prévios sobre IST/Aids, entretanto sugeriu a continuidade de programas educativos, voltados ao desenvolvimento de ações que visem orientação, informação, esclarecimentos com relação a sexualidade e IST/Aids (GALVÃO et al., 2003).

Bento (2005), em sua tese de doutorado, buscou levantar problemas vivenciados por uma população específica de nove surdos, adultos jovens, alunos de uma classe de Educação de Jovens e Adultos (EJA) frente à sexualidade e as IST/aids, utilizando a comunicação pela Língua de Sinais Brasileira (LIBRAS). A autora verificou que apresentavam dificuldades no que diz respeito aos conteúdos de educação básica, em relação ao corpo humano, bem como gravidez e parto. A palavra sexualidade não era de conhecimento dos surdos e grande parte dos entrevistados já havia tido experiências sexuais, sendo que camisinha, pílula anticoncepcional, fidelidade e casamento eram utilizados como meio de proteção para o sexo. Ainda foram realizadas, descritas e avaliadas as ações educativas com esses sujeitos.

Pode-se pensar que, certamente, teríamos inúmeras pesquisas científicas nas quais o enfermeiro trabalhe a questão da sexualidade e IST/aids com diversos grupos da nossa sociedade, porém observamos que existem poucos trabalhos em que este profissional se preocupe com a formação do aluno de graduação em enfermagem.

Tavares (1985) apresentou uma proposta para a estruturação de um programa de educação sexual nas escolas de $1^{\circ}$ e $2^{\circ}$ graus (atual Ensino Fundamental e Médio), a ser desenvolvido nos cursos de licenciatura em enfermagem, de modo a habilitar os futuros enfermeiros para este novo campo de competência da enfermagem. Ao final, a autora apresenta uma proposta de programa tomando como base o Manual de curso básico de 
formação para educadores sexuais. Finaliza seu trabalho ressaltando que o enfermeiro, como profissional da área da saúde que carrega no bojo de suas atividades, predominantemente, o papel de educador, seria o indicado para desempenhar função de educador sexual no ensino básico.

Ribeiro (1989) realizou um inquérito por meio do qual foi possível conhecer o preparo do estudante de enfermagem para prestar assistência à criança e ao adolescente no que diz respeito à sexualidade humana. A autora, em suas considerações finais, ressalta que a diversidade de respostas encontradas em seu estudo conduz à necessidade de discutir o assunto, visando proporcionar oportunidade de crescimento pessoal ao aluno e conseqüente melhora da assistência de enfermagem à criança, e assim, evitar a reprodução de uma educação ideológica repressiva sobre a sexualidade infantil.

Garcia (1993) preocupou-se em realizar uma análise crítica das Teorias das Necessidades Humanas Básicas, descrita por Horta, justificando a necessidade e propondo a inclusão, no currículo de graduação em enfermagem, de uma disciplina que capacite o aluno a lidar com a sexualidade de seu paciente.

Gir, Nogueira e Pelá (2000) trabalharam com alunos do último ano da graduação em enfermagem, buscando verificar as noções que o graduando tem sobre a temática sexualidade e identificando alguns temas da sexualidade que foram vivenciados pelo aluno durante as suas atividades acadêmicas. Concluíram que os alunos em sua maioria apresentam noções fluídas e limitadas sobre sexualidade, chegando a empregar o termo "sexo" e "sexualidade" como sinônimos. Relatam ainda que os futuros enfermeiros sentem falta de adquirir mais conhecimento sobre sexualidade.

Portanto, fundamentada nestes dados, desenvolvemos esta pesquisa com alunos de graduação em enfermagem, procurando conhecer melhor o seu comportamento sexual, assim como a sua percepção em relação ao curso de graduação em enfermagem, o qual se apresenta 
com co-responsável por instrumentalizá-los para uma vida saudável e responsável e também para o desenvolvimento de uma prática profissional competente. Isto nos permite destacar a importância deste estudo.

\subsection{O Referencial Teórico-Metodológico}

Ao entendermos ser necessário a compreensão da dinâmica com a qual os sujeitos interagem com o mundo e com tudo que o cercam, destacamos a importância da abordagem qualitativa, a qual nos possibilitaria aproximar desses fatos e interpretá-los. Neste processo, os dados quantitativos apenas nos serviram para dar complementaridade ao nosso estudo, fundamentalmente, no que concerne aos dados sócio-demográficos.

Neste sentido, Minayo (1994) refere que o conjunto de dados quantitativos e qualitativos não se opõem, mas, pelo contrário, complementam-se, uma vez que a realidade abrangida por eles interage, dinamicamente, excluindo qualquer dicotomia.

Triviños (1990) destaca que, atualmente, têm surgido pesquisas de diferentes abordagens que apresentam quantificação dos dados, sobretudo, quando o pressuposto requer consenso, fortalecimento pela qualificação e interpretação dos resultados apresentados.

Para Minayo (1994), a pesquisa qualitativa "é capaz de trabalhar com o universo de significados, motivos, aspirações, crenças, valores e atitudes, o que corresponde a um espaço mais profundo das relações, dos processos e dos fenômenos que não podem ser reduzidos à operacionalização de variáveis”.

No presente estudo, utilizamos a pesquisa-ação, a qual permite levantar problemas e desenvolver ação educativa, além de facilitar o envolvimento do pesquisador/pesquisando numa prática participativa. Pressupõe ainda a necessidade de um referencial teórico para ter 
sentido, em que a mediação teórica conceitual e metodológica permanece operando na investigação (THIOLLENT, 1992).

Na pesquisa-ação, é possível buscar a abordagem quantitativa na busca numérica e a abordagem qualitativa na compreensão e interpretação dos achados (GIORDANI, 2003; BENTO, 2005).

Optamos por trabalhar com a observação participante e aproximamos-nos de Minayo (2004); depreendemos que essa observação é um processo pelo qual se mantém a presença do observador numa situação social, com a finalidade de realizar uma investigação científica.

Bodgan e Biklen (1997), em uma perspectiva sociológica, referem que a utilização da observação participante no percurso metodológico permite ao investigador introduzir-se no mundo dos pesquisados, tentando conhecê-los e deixando-se conhecer, ao ganhar a sua confiança e elaborar um registro escrito e sistemático de tudo aquilo que se ouve e que se observa.

Riley e Nelson (1976) afirmam ser somente com a observação que o pesquisador pode abordar o sistema como um todo e seus processos dinâmicos, revelando padrões de atitudes e mudanças nas estruturas de papéis que os próprios atores sociais não compreendem inteiramente.

Triviños (1990) ressalta que o fato de observar de maneira natural não é simplesmente um olhar, mas é destacar algo específico de um conjunto, como nas ciências sociais, por exemplo, em que, de um determinado evento ou contexto social, foca-se a atenção para atos, atividades, significados e relações, entre outros.

Para Minayo (2004), a observação participante pode ser considerada parte essencial do trabalho de campo, na pesquisa qualitativa. Sua importância é de tal ordem que alguns estudiosos a tomam não apenas como uma estratégia no conjunto da investigação, mas como um método em si mesmo, para compreensão da realidade. 
Os dados foram coletados através de um questionário e analisados utilizando os pressupostos da análise temática preconizada por Freire (1992) e adaptada por Bueno (2001). Com isso, a partir dos educandos/pesquisandos, é possível criar oportunidades para que eles possam desenvolver e aperfeiçoar suas capacidades de compreenderem o mundo em que vivem (FREIRE, 2000; BUENO, 2001).

Para tanto, o método Paulo Freire, que é um método ativo, dialogal e crítico, possibilita buscar o conhecimento de como os educandos/pesquisandos pensam na realidade, o que pensam sobre ela, de modo que, ao tomar consciência, sejam criadores de cultura. Assim, trata-se de construir uma educação transformadora, em que o elemento norteador é o diálogo do educador/pesquisador com os educandos/pesquisados, numa relação horizontal. O desenvolvimento prático deste poderá proceder-se por meio de dois momentos descritos a seguir, conforme Freire apud Bueno (2001):

\section{1) Levantamento do Universo Temático $\left(^{*}\right)$}

Refere-se à descrição e à interpretação da situação do(s) educando(s)/pesquisando(s) e a identificação de suas necessidades de aprendizagem, de seus conhecimentos prévios e de habilidades. A organização da análise do universo temático segue as seguintes fases:

- Levantamento dos Temas Geradores. Esta fase, segundo Freire (1992), culmina com a busca de resultados muito ricos para os educadores, não só pelas relações que travam, mas pela busca da temática do pensamento dos homens, pensamento que se encontra somente no meio deles. Visa buscar, portanto, temas significativos com os participantes deste processo. Esta procura é o ponto de partida do processo de educação do tipo libertador. Como refere Freire (1992), o tema gerador é o pensamento do Homem sobre a realidade e sua ação sobre a

\footnotetext{
* Universo Temático: é o conjunto de temas geradores; a investigação deste Universo implica numa
} metodologia dialogada e conscientizadora (FREIRE, 2000). 
ação para esta realidade que está em sua práxis. Essas observações e a emissão dos significados e do pensamento acontecem no ambiente trabalhado (BUENO, 2001).

Conforme Triviños (1990) ressalta, as anotações de campo captam manifestações, ações do educando/pesquisando, o ambiente físico e reflexões do observador. Realiza-se com encontros do pesquisador com os pesquisandos, usando a observação participante durante as visitas e as entrevistas. Os temas trabalhados devem ser os mais significativos da vivência destes sujeitos.

- Organização do Material da Coleta de Dados. O conteúdo registrado é resultado da emissão dos significados e do pensamento dos educandos, captados na observação participante e/ou na aplicação de um instrumento, possibilitando interpretação e seleção dos assuntos centrais, conforme sugere Freire (1992). Processam-se a leitura detalhada de todas as observações e respostas emitidas pelos sujeitos pesquisados. É nesta fase que se faz um recorte do texto, selecionando frases ou palavras repetidas com mais freqüência ou colocadas com mais ênfase pelos sujeitos participantes do estudo e que forem passíveis de serem trabalhadas na atividade educativa. Aqui, é possível juntar pensamento para depois reunir os pesquisandos com elementos em comum (BUENO, 2001).

- Seleção e Codificação de Palavras e Frases Registradas/Emitidas. Segundo Freire apud Bueno (1997-8), são selecionadas, em ordem definida, algumas palavras e/ou frases que possam ser agrupadas pela riqueza temática, codificando-se os temas geradores (categorização).

Na análise dos dados é trabalhada a categorização (com indicadores convergentes e/ou divergentes), que foi empregada para se estabelecer as classificações dos eixos temáticos que suscitaram a ação/intervenção educativa.

Para Gomes (1994, p.70) trabalhar com categorias significa “agrupar elementos, idéias ou expressões em torno de um conceito capaz de abranger tudo isso”. Aqui surgem, 
portanto, as convergências e as divergências de idéias que exigem um planejamento textualizado e adequado do programa em foco, retratando assim as questões diagnosticadas daquela realidade pesquisada.

- Síntese das Palavras e Frases Selecionadas. Selecionados e codificados os temas geradores, agrupam-se todas as palavras e frases relacionadas ao tema gerador, reunindo grandes temas (Freire apud BUENO, 1997-8).

- Ordem dos Temas Geradores. Ordenam-se os temas geradores, pedagogicamente, numa seqüência lógica no planejamento e execução das atividades educativas estabelecidas (Freire apud BUENO, 1997-8).

- Ação/Intervenção Educativa. O método educativo na pesquisa-ação, proposta por Freire (2000), está voltado para uma educação libertadora/problematizadora, propiciando o desenvolvimento do homem como um todo, tornando-o agente de sua própria transformação. O autor propõe então uma educação conscientizadora, que é parte da experiência e da percepção do educando. A sua trajetória metodológica pressupõe a observação participante.

As bases pedagógicas para a Educação Sexual, sobremaneira aquelas direcionadas à prevenção das IST/aids, possibilitam firmar-se no diálogo aberto, na linguagem comum, simples, concisa e acessível, permitindo conhecimentos e habilidades adequados para a mudança de comportamento, desmistificando os preconceitos e tabus, os medos, as inseguranças, a ignorância e as crendices populares (BUENO, 1997-8).

2) Desenvolvimento das Atividades Educativas da Pesquisa Ação - É apontado, segundo Freire apud Bueno (1997-8):

- Planos de Ensino Relativos aos Temas Geradores. Elabora-se o planejamento de ensino, considerando-se cada tema gerador levantado. 
- Desenvolvimento da Educação Conscientizadora. Implementa-se o plano de ensino, iniciando-se com as situações/problema codificados para a seguir, serem decodificados $\left({ }^{*}\right)$ pelos sujeitos pesquisandos e pesquisadores. O debate em torno delas proporcionará ao grupo a conscientização.

O ideal é conhecer ou inserir-se no grupo a pesquisar e no contexto de investigação, pois a interação prévia favorece aproximação. O próprio projeto de investigação, a pesquisaação, pressupõe uma relação de participação entre pesquisando e pesquisador. Juntos, refletem e procuram elucidar os problemas. Manifestações verbais e participação ativa dos sujeitos refletem a eficácia das ações educativas implementares.

- Avaliação do Processo. A abordagem adequada das ações propostas e implementadas é evidenciada no discurso que passa a ser utilizado em freqüência pelo sujeito pesquisado/educando, com compreensão do seu significado, com adoção de termos adequados. O final deve ser avaliado de forma aberta, para propiciar a solução dos problemas.

* Decodificação é a análise crítica da situação existencial codificada, feita pelos educandos e educadores, levando os educandos a conscientização à medida que se alfabetiza. 
METODOLOGIA $\overline{\overline{2}}$ 


\subsection{Tipo de pesquisa}

A presente pesquisa constitui um estudo descritivo-exploratório, mediatizado pela metodologia da pesquisa-ação. Retrata uma abordagem qualitativa, que pode incorporar a utilização também da técnica quantitativa, para complementação dos dados. Trabalhamos junto aos alunos do curso de graduação em enfermagem de uma cidade do interior paulista. Assim, procuramos analisar, interpretar e compreender as dificuldades levantadas em relação a sua saúde sexual e reprodutiva, bem como a sua atividade profissional, frente às amplas questões que permeiam as temáticas atreladas a sexualidade e as IST/aids.

O nosso trabalho se divide em três momentos distintos:

$1^{\circ}$ Momento: Observação Participante

$2^{\circ}$ Momento: Levantamento do Universo Temático

$3^{\circ}$ Momento: Intervenção Educativa

\section{$1^{\circ}$ Momento: Observação Participante}

Num primeiro momento, considerando o nosso objeto de estudo, foi necessário trabalhar com a observação participante para melhor compreender o ambiente e os sujeitos a serem pesquisados. Esta técnica nos permitiu conhecer melhor o local pesquisado, bem como os participantes trabalhados, pois estes são de fundamental importância para nos apropriarmos dessa realidade, para o registro dos fatos. Da mesma forma, o observador está em relação face a face com os observados e, ao participar da vida deles, no seu cenário cultural, podemos coletar, efetivamente, esses dados.

Isto posto, leva-nos a crer que a observação participante prescinde de tempo (a curto, médio e longo prazo), visto que ela é realizada durante todo o percurso da pesquisa, ou seja, 
antes, durante e após a aplicação do instrumento, e do encontro para o desenvolvimento da oficina pedagógica (desenvolvimento das ações/intervenções educativas), bem como, após a efetivação da dissertação de mestrado, na devolução dos achados à instituição.

\section{$2^{\circ}$ Momento: Levantamento dos problemas}

\subsection{Local da Pesquisa}

A pesquisa foi realizada em uma faculdade pública de uma cidade do interior paulista.

\subsection{Sujeitos da Pesquisa}

Participaram da pesquisa os alunos do $1^{\circ}$ e $4^{\circ}$ ano do curso de graduação em Enfermagem que aceitaram participar do estudo e assinaram o termo de consentimento livre e esclarecido. A amostra se constituiu de 59 alunos, sendo 29 do $1^{\circ}$ ano e 30 do $4^{\circ}$ ano de graduação da referida instituição.

Optamos pela escolha dos alunos do $1^{\circ}$ e $4^{\circ}$, pois tínhamos a inquietação de saber como o aluno que está iniciando a faculdade vê o papel da graduação em relação à aprendizagem da temática sexualidade e IST/aids, assim como saber onde este aluno adquiriu informação sobre essa temática. Em relação ao $4^{\circ}$ ano, tivemos o interesse em saber o quanto a universidade contribuiu para a formação desse futuro profissional, tendo em vista sua atuação futura no que diz respeito à temática em apreço. 


\subsection{Critérios de inclusão dos sujeitos à pesquisa}

Para participação da pesquisa, foi necessário que o aluno:

- se manifestasse, espontaneamente, a participar do estudo, após a explicação e assinatura do termo de consentimento livre e esclarecido;

- fosse maior de 18 anos;

- estivesse cursando regularmente o $1^{\circ}$ ou o $4^{\circ}$ ano do Curso de Graduação em Enfermagem;

- estivesse presente no dia pré-determinado pelos autores para a coleta de dados.

\subsection{Procedimentos para a coleta e análise dos dados}

No momento da coleta de dados, foi realizado o levantamento dos problemas, por meio de um questionário, contendo questões mistas: abertas e fechadas (Apêndice A). Os questionários foram devidamente preenchidos no intervalo de aula, quando tivemos a oportunidade de conversar com os alunos a respeito do termo de consentimento livre e esclarecido (Apêndice B) e dos objetivos do trabalho e da solicitação de participação no estudo e na oficina pedagógica.

Optamos pelo desenvolvimento da pesquisa-ação, investigando o estudo em foco, levantando problemas e propondo a realização de intervenções educativas, já que nas pesquisas científicas encontradas na literatura, voltadas à sexualidade e IST/aids, esta metodologia tem trazido resultados significantes, aplicadas em diversas instituições escolares.

Os dados foram dispostos em uma planilha do programa informatizado Excel, para melhor visualização dos resultados. Após o levantamento da matriz, foram elaborados tabelas e quadros, que favoreceram a análise dos achados.

Este momento foi consolidado após o levantamento dos problemas, no qual obtivemos a análise dos dados referentes às necessidades identificadas por meio da emissão das respostas 
dos questionários, de onde retiramos as palavras-chave (temas geradores). Esses permitiram elaborar as categorias, resultando em eixos temáticos que serviram de subsídios para o desenvolvimento das ações educativas realizadas na oficina pedagógica.

Posteriormente, elaboramos um plano didático-pedagógico para o desenvolvimento das ações educativas através da oficina pedagógica, de forma participativa, com os graduandos.

\section{$3^{\circ}$ Momento: Intervenção Educativa}

O terceiro momento desta pesquisa ocorreu com o desenvolvimento de uma oficina pedagógica (espaço destinado para as ações/intervenções educativas). Esta técnica didática aconteceu de forma participativa, integrativa e dialogal, contrapondo-se à concepção "bancária" (tradicional), avançando para uma concepção conscientizadora, humanista e libertadora do ato de educar, respeitando a vocação ontológica do homem de ser mais (FREIRE, 1997).

Nesta oficina, desenvolvemos os temas geradores identificados pelas falas dos alunos, trabalhando técnicas de dinâmica de grupo como discussão, debate e simulação de casos, e com isto nos identificando dentro da concepção pedagógica crítico-social freireana, valorizando sobremaneira o ato de humanização.

\subsection{Procedimento para a realização da Pesquisa}

Para a elaboração deste trabalho, alguns passos foram seguidos:

- Solicitação de autorização junto ao Departamento de Enfermagem da Instituição pesquisada, para realizar a pesquisa com os alunos do curso de graduação em enfermagem; 
- Submissão do Projeto ao Comitê de Ética da Faculdade pesquisada, o qual foi aprovado (Anexo A). Ressalte-se que, após o exame de qualificação, houve a mudança do título da dissertação (Anexo B);

- Informação aos sujeitos da pesquisa sobre a importância deste trabalho, levando em conta os aspectos éticos e o rigor científico, bem como firmando o termo de consentimento livre e esclarecido (TCLE) com aqueles que participaram espontaneamente do estudo. Ressalte-se que uma via do TCLE ficou com o aluno e outra via com os autores (Apêndide B);

- Aplicação dos procedimentos da coleta de dados através da observação participante (diário de campo) e questionário (Apêndice A);

- Análise dos dados;

- Complementação dos dados bibliográficos;

- Revisão final da introdução e do referencial teórico;

- Realização da análise dos dados e posteriormente o desenvolvimento da oficina pedagógica;

- Finalização da conclusão e das considerações finais;

- Encaminhamento para publicação do trabalho parcial e final;

- Defesa da dissertação de mestrado.

\subsection{Definição de Termos}

Para melhor esclarecimento desta investigação, vale ressaltar o significado de alguns termos utilizados diversas vezes no decorrer deste projeto de pesquisa, que são eles: 
- Sexualidade: é entendida como um processo intrínseco do ser e representa muito mais do que o ato sexual em si, pois, muitas vezes, o sexo conota um ato fisiológico, enquanto a sexualidade considera a totalidade do ser. No seu sentido mais amplo, sexualidade acaba por ser definida como um aspecto mais profundo e penetrante da personalidade total, a soma geral, mas como ser e estar homem e mulher (MAMEDE et al., 1996; BUENO, 1997-8).

- Pesquisa-ação: é um tipo de pesquisa social com base empírica que é concebida e realizada em estreita associação com uma ação ou com a resolução de um problema coletivo no qual os pesquisadores e os participantes representativos da situação ou do problema estão envolvidos de modo cooperativo e participativo (THIOLLENT, 1992).

- Vulnerabilidade: é o esforço de produção e difusão de conhecimento, debate e ação sobre os diferentes graus e naturezas da suscetibilidade de indivíduos e coletividades à infecção, adoecimento ou morte pelo HIV/AIDS, segundo a particularidade de sua situação quanto ao conjunto integrado dos aspectos sociais (ou contextuais), pragmáticos (ou institucionais) e individuais (ou comportamentais) que os põem em relação com o problema e com os recursos para seu enfrentamento. No plano individual, a avaliação da vulnerabilidade ocupa-se, basicamente, dos comportamentos que criam a oportunidade de infectar-se e/ou adoecer, nas diversas situações já conhecidas de transmissão do HIV (relação sexual, uso de drogas injetáveis, transfusão sangüínea e transmissão vertical). Considera-se, entretanto, que os comportamentos associados à maior vulnerabilidade não podem ser entendidos como decorrência imediata da vontade dos indivíduos, mas relacionam-se ao grau de consciência que estes indivíduos têm dos possíveis danos decorrentes de tais comportamentos e ao poder de transformação efetiva de comportamentos a partir dessa consciência (AYRES et al., 1997). 
RESULTADOS E DISCUSSÃO 
Os resultados encontrados com esta pesquisa e sua respectiva discussão serão descritos em três etapas.

\section{$1^{\circ}$ Etapa}

Inicialmente apresentaremos os dados da instituição coletados através da observação participante.

\section{$2^{\circ}$ Etapa}

Nesta seção, apresentaremos os resultados e as discussões deste trabalho de acordo com a seqüência dos objetivos propostos, assim como a ordem estabelecida no instrumento aplicado para a presente investigação. Esses achados foram analisados e discutidos em duas fases: a primeira foi trabalhada identificando a caracterização dos sujeitos pesquisados (dados sócio-demográficos); na segunda fase, foram discutidos, analisados e interpretados os dados propriamente ditos sobre as questões da sexualidade e IST/aids.

\section{$3^{\circ}$ Etapa}

Finalmente, elaboramos o Plano pedagógico e apresentamos as ações/intervenções educativas do processo realizado na oficina pedagógica, assim como a avaliação dos alunos. 


\section{$1^{\circ}$ Etapa}

A graduação em enfermagem na instituição pesquisada possui, aproximadamente, 120 alunos. Desses, procuramos, neste estudo, pesquisar aqueles que estão em fase inicial de vida acadêmica e aqueles que já estão finalizando a sua graduação. No total, foram 59 alunos, sendo 29 do $1^{\circ}$ ano e 30 do $4^{\circ}$ ano. A presente pesquisa contou com a presença maciça dos alunos tanto do $1^{\circ}$ e do $4^{\circ}$ ano.

Ressaltamos neste momento algo que nos estimulou a desenvolver a presente pesquisa. Desde os primeiros contatos com os acadêmicos, em sala de aula, percebemos a curiosidade da grande maioria dos alunos em saber do que se tratava exatamente a nossa pesquisa. Questionaram-nos sobre a questão do sigilo dos dados, do modo como seria desenvolvida a oficina pedagógica e por fim solicitaram que os mesmos gostariam de saber o resultado final da dissertação. Certamente, todo esse questionamento por parte dos alunos teve um papel importante no desenvolvimento da pesquisa, pois conseguimos perceber que esses sujeitos estavam realmente interessados em discutir sobre os temas relacionados à sexualidade humana.

Acreditamos que os contatos que tivemos no início da pesquisa foram fundamentais para que os alunos se sentissem mais à vontade durante o preenchimento do questionário, mas principalmente no decorrer da oficina pedagógica, que será relatada na $3^{\circ}$ etapa da pesquisa.

Vale ressaltar que desde o início da pesquisa obtivemos total apoio das instâncias superiores da instituição para o desenvolvimento pleno desta investigação. 


\section{$2^{\circ}$ Etapa}

\section{$1^{\text {a }}$ Fase - Caracterização dos sujeitos participantes da pesquisa}

Tabela 1 - Distribuição numérica e percentual dos alunos de $1^{\circ}$ e $4^{\circ}$ ano em relação ao aspecto sócio-demográfico, segundo faixa etária, sexo, estado civil, religião e com quem mora, 2006

\begin{tabular}{|c|c|c|c|c|c|c|c|}
\hline \multirow{2}{*}{\multicolumn{2}{|c|}{ CARACTERIZAÇÃO }} & \multicolumn{2}{|c|}{$\begin{array}{c}1^{\circ} \text { ANO } \\
\text { GRADUAÇÃO } \\
\text { N = 29 }\end{array}$} & \multicolumn{2}{|c|}{$\begin{array}{c}4^{\circ} \text { ANO } \\
\text { GRADUAÇÃO } \\
\text { N = } 30\end{array}$} & \multicolumn{2}{|c|}{$\begin{array}{l}\text { TOTAL } \\
\mathrm{N}=59\end{array}$} \\
\hline & & $\mathbf{N}^{\circ}$ & $\%$ & $\mathbf{N}^{\circ}$ & $\%$ & $\mathbf{N}^{\circ}$ & $\%$ \\
\hline Faixa etária & $\begin{array}{c}18 \text { a } 19 \\
20 \text { a } 21 \\
22 \text { a } 23 \\
24 \text { a } 25 \\
\geq 25\end{array}$ & $\begin{array}{l}16 \\
07 \\
04 \\
02 \\
00\end{array}$ & $\begin{array}{c}55,2 \\
24,1 \\
13,8 \\
6,9 \\
0,0\end{array}$ & $\begin{array}{l}00 \\
07 \\
16 \\
06 \\
01\end{array}$ & $\begin{array}{c}0,0 \\
23,3 \\
53,3 \\
20,0 \\
3,3\end{array}$ & $\begin{array}{l}16 \\
14 \\
20 \\
08 \\
01\end{array}$ & $\begin{array}{c}27,1 \\
23.7 \\
33,9 \\
13,6 \\
1,7\end{array}$ \\
\hline Sexo & $\begin{array}{l}\text { Feminino } \\
\text { Masculino }\end{array}$ & $\begin{array}{l}26 \\
03\end{array}$ & $\begin{array}{c}93,1 \\
6,9\end{array}$ & $\begin{array}{l}28 \\
02\end{array}$ & $\begin{array}{c}93,3 \\
6,7\end{array}$ & $\begin{array}{l}54 \\
05\end{array}$ & $\begin{array}{c}91,5 \\
8,5\end{array}$ \\
\hline Estado civil & Solteiro & 29 & 100,0 & 30 & 100,0 & 59 & 100,0 \\
\hline Religião & $\begin{array}{l}\text { Católico } \\
\text { Espírita } \\
\text { Evangélico } \\
\text { Protestante } \\
\text { Outra }\end{array}$ & $\begin{array}{l}17 \\
05 \\
04 \\
01 \\
02\end{array}$ & $\begin{array}{c}58,6 \\
17,2 \\
13,8 \\
3,5 \\
6,9\end{array}$ & $\begin{array}{l}16 \\
07 \\
04 \\
03 \\
00\end{array}$ & $\begin{array}{c}53,4 \\
23,3 \\
13,3 \\
10,0 \\
0,0\end{array}$ & $\begin{array}{l}33 \\
12 \\
08 \\
04 \\
02\end{array}$ & $\begin{array}{c}55,9 \\
20,3 \\
13,6 \\
6,8 \\
3,4\end{array}$ \\
\hline $\begin{array}{c}\text { Com quem } \\
\text { mora }\end{array}$ & $\begin{array}{c}\text { Sozinho } \\
\text { Com amigos } \\
\text { Casa dos pais e/ou parentes } \\
\text { Com namorado } \\
\text { Pensão e/ou moradia } \\
\text { estudantil } \\
\text { Outros } \\
\text { Não respondeu }\end{array}$ & $\begin{array}{l}03 \\
14 \\
04 \\
00 \\
05\end{array}$ & $\begin{array}{c}10,3 \\
48,3 \\
13,8 \\
0,0 \\
17,2\end{array}$ & $\begin{array}{l}04 \\
21 \\
01 \\
01 \\
01\end{array}$ & $\begin{array}{l}13,4 \\
70,0 \\
3,3 \\
3,3 \\
3,3\end{array}$ & $\begin{array}{l}07 \\
35 \\
05 \\
01 \\
06\end{array}$ & $\begin{array}{c}11,9 \\
59,3 \\
8,5 \\
1,7 \\
10,1\end{array}$ \\
\hline
\end{tabular}

Conforme a Tabela 1, verificamos que os sujeitos pesquisados estão predominantemente em faixa etária entre 18 a 25 anos, fase caracterizada enquanto adulto jovem; sendo a maioria mulheres, solteiros, católicos e já morando fora do convívio familiar, para a efetivação de seus estudos acadêmicos. 


\section{$2^{\text {a }}$ Fase - Questões sobre a temática da pesquisa propriamente dita}

- Conhecimento geral sobre o comportamento sexual, tendo em vista a sexualidade, riscos às IST/aids e métodos contraceptivos.

Tabela 2 - Distribuição numérica e percentual das respostas dos alunos de $1^{\circ}$ e $4^{\circ}$ ano quanto às questões: No momento você está namorando? e Você mantém relacionamentos esporádicos? 2006

\begin{tabular}{|c|c|c|c|c|c|c|c|}
\hline \multicolumn{2}{|c|}{ RELACIONAMENTO } & \multicolumn{2}{|c|}{$\begin{array}{c}1^{\circ} \text { ANO } \\
\text { GRADUAÇÃO } \\
\text { N = 29 }\end{array}$} & \multicolumn{2}{|c|}{$\begin{array}{c}4^{\circ} \text { ANO } \\
\text { GRADUAÇÃO } \\
\text { N = } 30\end{array}$} & \multicolumn{2}{|c|}{$\begin{array}{l}\text { TOTAL } \\
\text { N = 59 }\end{array}$} \\
\hline & & $\mathbf{N}^{\circ}$ & $\%$ & $\mathbf{N}^{\circ}$ & $\%$ & $\mathbf{N}^{\circ}$ & $\%$ \\
\hline $\begin{array}{l}\text { No momento está } \\
\text { namorando }\end{array}$ & $\begin{array}{l}\text { Sim } \\
\text { Não }\end{array}$ & $\begin{array}{l}14 \\
15\end{array}$ & $\begin{array}{l}48,3 \\
51,7\end{array}$ & $\begin{array}{l}21 \\
09\end{array}$ & $\begin{array}{l}70,0 \\
30,0\end{array}$ & $\begin{array}{l}35 \\
24\end{array}$ & $\begin{array}{l}59,3 \\
40,7\end{array}$ \\
\hline $\begin{array}{l}\text { Mantém } \\
\text { relacionamento } \\
\text { esporádico }\end{array}$ & $\begin{array}{l}\text { Sim } \\
\text { Não }\end{array}$ & $\begin{array}{l}15 \\
14\end{array}$ & $\begin{array}{l}51,7 \\
48,3\end{array}$ & $\begin{array}{l}09 \\
21\end{array}$ & $\begin{array}{l}30,0 \\
70,0\end{array}$ & $\begin{array}{l}24 \\
35\end{array}$ & $\begin{array}{l}40,7 \\
59,3\end{array}$ \\
\hline
\end{tabular}

A Tabela 2 evidencia que, entre os estudantes pesquisados, a maioria respondeu afirmativamente, que naquele momento estava namorando. No entanto, não encontramos apenas o namoro como a única forma de relacionamento, já que, entre os que responderam que não estão namorando, 40,7\% referiram manter relacionamentos esporádicos.

Pirotta e Schor (2004), por meio de um trabalho realizado com universitários de uma faculdade pública de São Paulo, concluíram que 45,8\% dos estudantes estavam namorando no momento da entrevista, enquanto $83,8 \%$ mantinham relacionamento sexual com parceiros (as) esporádicos (as).

Devemos ressaltar que no nosso estudo não foi especificado se no relacionamento esporádico havia ou não a presença da relação sexual. 
Tabela 3 - Distribuição numérica e percentual das respostas dos alunos de $1^{\circ}$ e $4^{\circ}$ ano em relação às questões: Iniciou a vida sexual?, Com quantos anos você teve a $1^{\circ}$ relação sexual e A sua primeira relação sexual foi com quem? 2006

\begin{tabular}{|c|c|c|c|c|c|c|c|}
\hline \multirow[t]{2}{*}{$\begin{array}{l}\text { CATEGORIAS } \\
\text { SEGUNDO A } \\
\text { VIDA SEXUAL }\end{array}$} & \multirow[t]{2}{*}{ RESPOSTAS } & \multicolumn{2}{|c|}{$\begin{array}{c}1^{\circ} \text { ANO } \\
\text { GRADUAÇÃO } \\
\mathbf{N}=\mathbf{2 9} \\
\end{array}$} & \multicolumn{2}{|c|}{$\begin{array}{c}4^{\circ} \text { ANO } \\
\text { GRADUAÇÃO } \\
\text { N = 30 }\end{array}$} & \multicolumn{2}{|c|}{$\begin{array}{l}\text { TOTAL } \\
\mathrm{N}=59 \\
\end{array}$} \\
\hline & & $\mathbf{N}^{\circ}$ & $\%$ & $\mathbf{N}^{\circ}$ & $\%$ & $\mathbf{N}^{\circ}$ & $\%$ \\
\hline $\begin{array}{l}\text { Iniciou a vida } \\
\text { sexual }\end{array}$ & $\begin{array}{l}\text { Sim } \\
\text { Não }\end{array}$ & $\begin{array}{l}19 \\
10\end{array}$ & $\begin{array}{l}65,5 \\
34,5\end{array}$ & $\begin{array}{l}29 \\
01\end{array}$ & $\begin{array}{c}96,7 \\
3,3\end{array}$ & $\begin{array}{l}48 \\
11\end{array}$ & $\begin{array}{l}81,4 \\
18,6\end{array}$ \\
\hline $\begin{array}{l}{\text { Idade da } 1^{\text {a }}}^{\text {relação }} \\
\text { sexual * }\end{array}$ & $\begin{array}{c}15 \text { a } 16 \\
17 \text { a } 18 \\
19 \text { a } 20 \\
21 \text { a } 22 \\
\geq 23 \\
\text { Não iniciou vida } \\
\text { sexual }\end{array}$ & $\begin{array}{l}04 \\
12 \\
02 \\
01 \\
00 \\
10\end{array}$ & $\begin{array}{c}13,8 \\
41,3 \\
6,9 \\
3,5 \\
0,0 \\
34,5\end{array}$ & $\begin{array}{l}05 \\
14 \\
05 \\
03 \\
02 \\
01\end{array}$ & $\begin{array}{c}16,7 \\
46,7 \\
16,7 \\
10,0 \\
6,6 \\
3,3\end{array}$ & $\begin{array}{l}09 \\
26 \\
07 \\
04 \\
02 \\
11\end{array}$ & $\begin{array}{c}15,2 \\
44,1 \\
11,9 \\
6,8 \\
3,4 \\
18,6\end{array}$ \\
\hline $\begin{array}{c}\text { Com quem foi a } \\
1^{\text {a }} \text { relação } \\
\text { sexual * }\end{array}$ & $\begin{array}{c}\text { Namorado (a) } \\
\text { Outro** } \\
\text { Não respondeu (não } \\
\text { iniciou a vida sexual) }\end{array}$ & $\begin{array}{l}16 \\
03 \\
10\end{array}$ & $\begin{array}{l}55,2 \\
10,3 \\
34,5\end{array}$ & $\begin{array}{l}22 \\
07 \\
01\end{array}$ & $\begin{array}{c}73,4 \\
23,3 \\
3,3\end{array}$ & $\begin{array}{l}38 \\
10 \\
11\end{array}$ & $\begin{array}{l}64,4 \\
17,0 \\
18,6\end{array}$ \\
\hline
\end{tabular}

Em relação ao início da vida sexual, observamos na Tabela 3 que a grande maioria dos entrevistados refere já ter iniciado a sua vida sexual, e, ao evidenciarmos a idade da primeira relação sexual, os dados revelam ter sido na maioria durante a adolescência, entre 15 a 20 anos.

Do total, obtivemos que $44,1 \%$ dos alunos iniciaram a sua vida sexual entre 17 e 18 anos, o que ressalta os resultados encontrados em um amplo estudo populacional brasileiro desenvolvido por Abdo (2006), a qual encontrou que as brasileiras que têm hoje entre 18 e 25 anos tiveram o início da vida sexual aos 17 anos, enquanto os brasileiros com a mesma idade começaram aos 14 anos e meio.

Em sua pesquisa com estudantes universitários, Pirotta e Schor (2004) tiveram como resultados que $73 \%$ dos entrevistados haviam iniciado a vida sexual, sendo que $83,3 \%$ tiveram sua primeira relação sexual entre 15 a 19 anos. 
Bandeira e Diógenes (2006) observaram que, entre os universitários de enfermagem da Faculdade de Fortaleza, 58,5\% iniciaram a sua vida sexual entre 17 e 21 anos, 28,3\% entre 12 e 16 anos, 7,6\% deram início com idade superior a 21 anos e somente 5,6\% não tiveram relação sexual.

Abdo (2006), afirma que, nas últimas décadas, a idade da iniciação sexual no Brasil diminuiu em 5 anos para as mulheres e em 2 anos para os homens.

Em nosso estudo dos alunos que iniciaram a atividade sexual, a maioria (64,4\%) relatou ter tido a sua primeira relação sexual com o namorado (a).

Bento (2000) encontrou em seu estudo que 65\% dos universitários entrevistados também iniciaram a sua prática sexual com o namorado(a). A autora faz referência a D’Andréa in Bueno (1985) e ressalta que o fato de a primeira relação sexual ter acontecido com o namorado (a) pressupõe a existência do vínculo afetivo, favorecendo o desenvolvimento da personalidade.

Por outro lado, encontramos que $17 \%$ iniciaram sua vida sexual com colega de turma, com amigo(a) e "ficante", pressupondo que não houve nenhum vínculo de compromisso com a afetividade com o parceiro(a).

Bento (2000) afirma que o tipo de companheiro escolhido para o início da vida sexual favorece a maior rotatividade de parceiros e promiscuidade, sem esquecer dos aspectos relacionados à vulnerabilidade.

Todavia, houve uma minoria, embora significativa $(18,6 \%)$, referindo não ter iniciado a prática sexual. Podemos observar que a maioria está concentrada no $1^{\circ}$ ano, o que nos leva a pensar como a fase da graduação é importantíssima para os alunos, pois aproximadamente $20 \%$ não iniciaram a vida sexual, vindo a fazê-lo justamente nesta fase, como já foi mostrado na pesquisa de Bento (2000) e Abdo (2006). 
Pirotta e Schor (2004) encontraram que $27 \%$ dos alunos entrevistados não haviam iniciado a vida sexual.

Ao observarmos os dados relacionados com o início da vida sexual, concordamos com Pirotta e Schor (2004, p.500) ao relatarem que

[...] os universitários vivenciaram a primeira relação sexual proximamente ao ingresso na vida universitária. Esse dado pode indicar o significado que esses dois eventos adquirem na vida desses jovens, como um rito de ingresso na vida adulta, em direção à autonomia e à independência.

Tabela 4 - Distribuição numérica e percentual das respostas dos alunos de $1^{\circ}$ e $4^{\circ}$ ano, segundo as questões: Você fez uso de algum tipo de método contraceptivo na $1^{\text {a }}$ relação sexual?, Qual o método contraceptivo usado e Se não usou, por quê? 2006

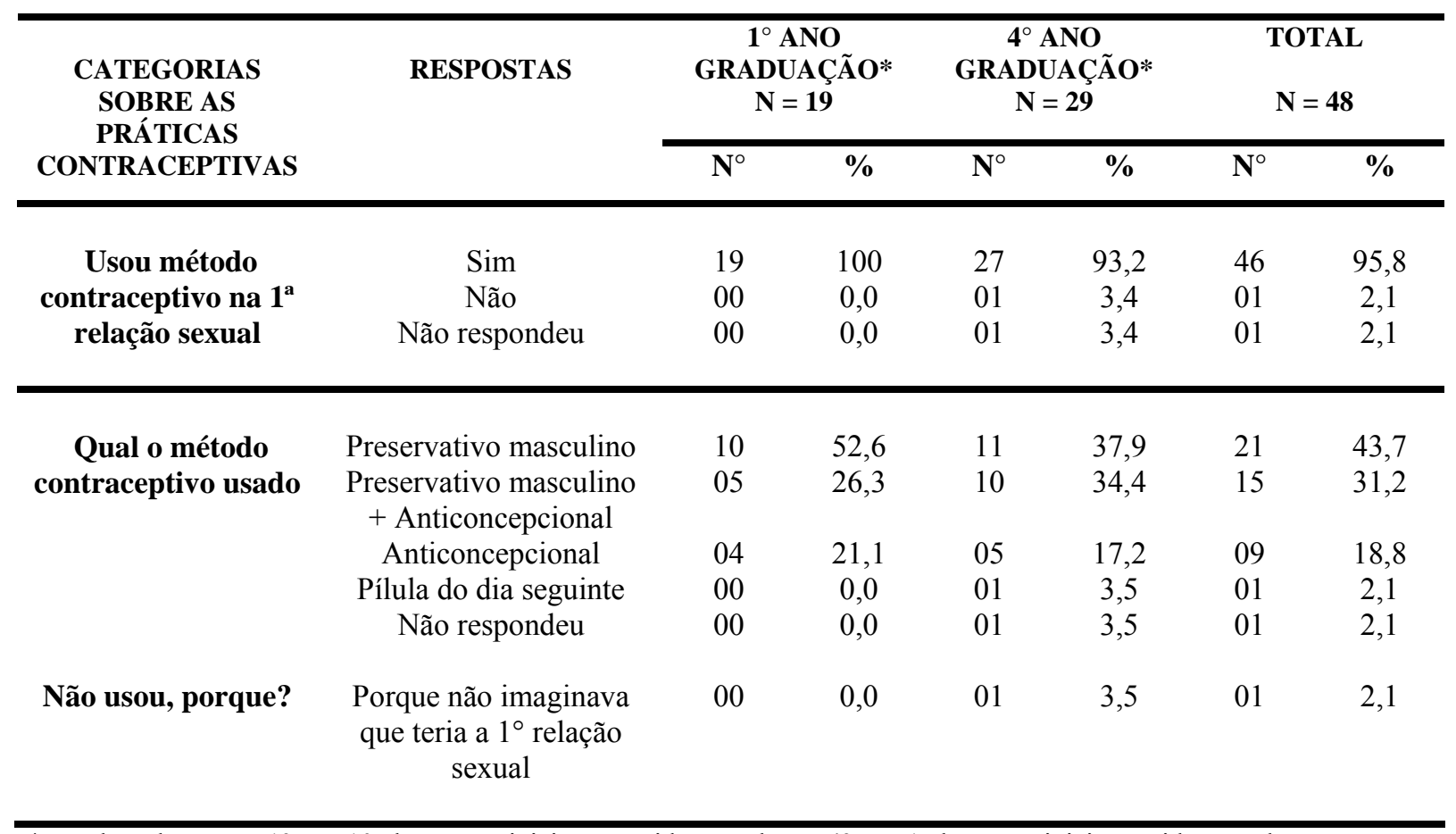

* Lembrando que no $1^{\circ}$ ano 10 alunos não iniciaram a vida sexual e no $4^{\circ}$ ano 1 aluno não iniciou a vida sexual.

A Tabela 4 evidencia que os sujeitos referiram uma alta freqüência de uso de método contraceptivo (95,8\%), enquanto Pirotta (2002) encontrou em seu estudo que $82,1 \%$ dos estudantes universitários entrevistados fizeram uso de algum método na primeira relação sexual. 
Dentre os métodos contraceptivos mais utilizados pelos universitários, tivemos o uso do preservativo masculino (43,7\%), e o mesmo associado com o anticoncepcional $(31,2 \%)$, e apenas o uso do anticoncepcional $(18,8 \%)$.

Ao compararmos o tipo de método contraceptivo utilizado na iniciação sexual, Pirotta (2002) nos mostra que $80,0 \%$ dos entrevistados fizeram uso de preservativo, dando uma diferença de aproximadamente $40 \%$ em relação aos dados encontrados na presente pesquisa.

Encontramos que apenas 7,7\% dos universitários fizeram uso do preservativo masculino associado à pílula e $4 \%$ utilizavam a pílula. Em menor escala, tivemos outros métodos como a pílula do dia seguinte, citada apenas por uma aluna.

Quanto à questão "Se não usou algum método contraceptivo?”, ainda na Tabela 4, apenas um respondeu não ter usado nenhum método na primeira relação sexual, justificando que "não imaginava que teria a primeira relação sexual".

A escolha do método contraceptivo está diretamente relacionada ao tipo de proteção que o jovem quer ter naquele momento. Quando se tem a escolha pelo uso do preservativo, ou associado com a pílula, podemos pensar que este sujeito está preocupado em se proteger contra as IST/aids e uma possível gravidez, diferentemente daquele indivíduo que escolhe apenas a pílula anticoncepcional, pois sabe-se que a única proteção certamente será de uma gravidez, estando exposto a qualquer IST/aids. 
Tabela 5 - Distribuição numérica e percentual das respostas dos alunos de $1^{\circ}$ e $4^{\circ}$ ano segundo as questões: No seu relacionamento atual você e/ou seu parceiro (a) usam algum tipo de método contraceptivo? Se sim, qual?, Se não usou, por quê? e Onde você adquire esse método contraceptivo? 2006

\begin{tabular}{|c|c|c|c|c|c|c|c|}
\hline \multirow{2}{*}{$\begin{array}{c}\text { CATEGORIAS SOBRE } \\
\text { AS PRÁTICAS } \\
\text { CONTRACEPTIVAS } \\
\text { NO } \\
\text { RELACIONAMENTO } \\
\text { ATUAL }\end{array}$} & \multirow[t]{2}{*}{ RESPOSTAS } & \multicolumn{2}{|c|}{$\begin{array}{c}1^{\circ} \text { ANO } \\
\text { GRADUAÇÃO* } \\
\text { N = 19 }\end{array}$} & \multicolumn{2}{|c|}{$\begin{array}{c}4^{\circ} \text { ANO } \\
\text { GRADUAÇÃO* } \\
\text { N = 29 }\end{array}$} & \multicolumn{2}{|c|}{$\begin{array}{l}\text { TOTAL } \\
\mathbf{N}=48\end{array}$} \\
\hline & & $\mathbf{N}^{\circ}$ & $\%$ & $\mathbf{N}^{\circ}$ & $\%$ & $\mathbf{N}^{\circ}$ & $\%$ \\
\hline $\begin{array}{c}\text { Está usando método } \\
\text { contraceptivo no } \\
\text { relacionamento } \\
\text { atual? }\end{array}$ & $\begin{array}{c}\text { Sim } \\
\text { Não } \\
\text { Não respondeu }\end{array}$ & $\begin{array}{l}16 \\
03 \\
00\end{array}$ & $\begin{array}{c}84,2 \\
15,8 \\
0,0\end{array}$ & $\begin{array}{l}28 \\
00 \\
01\end{array}$ & $\begin{array}{c}96,5 \\
0,0 \\
3,5\end{array}$ & $\begin{array}{l}44 \\
03 \\
01\end{array}$ & $\begin{array}{c}91,6 \\
6,3 \\
2,1\end{array}$ \\
\hline $\begin{array}{l}\text { Se sim, qual o método } \\
\text { contraceptivo usado? }\end{array}$ & $\begin{array}{c}\text { Preservativo masculino } \\
\text { Preservativo masculino }+ \\
\text { Anticoncepcional } \\
\text { Preservativo masculino }+ \\
\text { pílula do dia seguinte } \\
\text { Anticoncepcional } \\
\text { Coito interrompido } \\
\text { Não respondeu }\end{array}$ & $\begin{array}{l}05 \\
05 \\
02 \\
04 \\
00 \\
00\end{array}$ & $\begin{array}{c}26,3 \\
26,3 \\
10,5 \\
21,1 \\
0,0 \\
0,0\end{array}$ & $\begin{array}{l}05 \\
14 \\
00\end{array}$ & $\begin{array}{c}17,2 \\
48,2 \\
0,0 \\
27,6 \\
3,5 \\
3,5\end{array}$ & $\begin{array}{l}12 \\
01 \\
01\end{array}$ & $\begin{array}{c}20,8 \\
39,6 \\
4,1 \\
25,0 \\
2,1 \\
2,1\end{array}$ \\
\hline Se não usou, porque? & $\begin{array}{c}\text { Por puro descuido } \\
\text { Porque não estou me } \\
\text { relacionando no momento }\end{array}$ & $\begin{array}{l}01 \\
02\end{array}$ & $\begin{array}{c}5,3 \\
10,5\end{array}$ & $\begin{array}{l}00 \\
00\end{array}$ & $\begin{array}{l}0,0 \\
0,0\end{array}$ & $\begin{array}{l}01 \\
02\end{array}$ & $\begin{array}{l}2,1 \\
4,1\end{array}$ \\
\hline $\begin{array}{l}\text { Onde adquiriu o } \\
\text { método } \\
\text { contraceptivo? }\end{array}$ & $\begin{array}{c}\text { Farmácia } \\
\text { Farmácia e Posto de saúde } \\
\text { Com o médico } \\
\text { Não responderam }\end{array}$ & $\begin{array}{l}14 \\
01 \\
01 \\
03\end{array}$ & $\begin{array}{c}73,6 \\
5,3 \\
5,3 \\
15,8\end{array}$ & $\begin{array}{l}20 \\
07 \\
00 \\
02\end{array}$ & $\begin{array}{c}69,0 \\
24,1 \\
0,0 \\
6,9\end{array}$ & $\begin{array}{l}34 \\
08 \\
01 \\
05\end{array}$ & $\begin{array}{c}70,8 \\
16,7 \\
2,1 \\
10,4\end{array}$ \\
\hline
\end{tabular}

* Lembrando que no $1^{\circ}$ ano temos que 10 alunos não iniciaram a vida sexual e no $4^{\circ}$ ano 1 aluno não iniciou a vida sexual.

$\mathrm{Na}$ Tabela 5 evidenciamos que maioria relatou uma alta presença do uso de um método contraceptivo no relacionamento atual $(91,6 \%)$, vindo ao encontro dos achados do estudo de Pirotta (2002), que encontrou um total de $96 \%$ de uso de contraceptivo.

Dentre os métodos utilizados, tivemos que 39,6\% usam o preservativo masculino associado à pílula anticoncepcional, seguido de $25 \%$ dos sujeitos que fazem uso apenas do anticoncepcional, e $20,8 \%$ que usam apenas o preservativo masculino. 
Ao compararmos os dados com Pirotta (2002), podemos notar algumas diferenças em relação ao método contraceptivo utilizado, como, por exemplo: $25,1 \%$ fazem uso do preservativo masculino associado à pílula, 16\% utilizam apenas o anticoncepcional e 44,4\% usam o preservativo. No presente estudo, percebemos que dois alunos utilizam a pílula do dia seguinte juntamente com o preservativo masculino e apenas um aluno faz uso do coito interrompido.

Enquanto método anticonceptivo científico e aceitável, a Anticoncepção de Emergência (AE), também conhecida como pílula do dia seguinte, é algo relativamente recente. Embora as primeiras investigações com hormônios sexuais para essa finalidade tenham cerca de três décadas, apenas nos últimos anos a $\mathrm{AE}$ passou a despertar maior interesse médico e ganhou difusão entre o público em geral (BRASIL, 2005c).

[...] entre as principais indicações de AE, está relação sexual sem uso de método anticonceptivo, falha conhecida ou presumida do método em uso de rotina, uso inadequado do anticonceptivo e abuso sexual. Essas situações são freqüentes. Entre as falhas dos anticonceptivos, podem-se citar rompimento do preservativo, algo bastante comum, ou deslocamento do diafragma. Esquecimento prolongado do anticonceptivo oral, atraso na data do injetável mensal, cálculo incorreto do período fértil, erro no período de abstinência ou interpretação equivocada da temperatura basal são circunstâncias que levam ao uso inadequado do método e expõem ao risco de gravidez. Nos casos de violência sexual, a mulher ou a adolescente é privada da possibilidade de escolha e submetida à gravidez indesejada. A AE não deve ser usada de forma planejada, previamente programada, ou substituir método anticonceptivo como rotina (BRASIL, 2005c).

Segundo o Ministério da Saúde, é necessário lembrar que o uso repetitivo ou freqüente da AE compromete sua eficácia, que será sempre menor do que aquela obtida com o uso regular do método anticonceptivo de rotina. Em suma, os resultados sobre eficácia são absolutamente claros para que se afirme que a $\mathrm{AE}$ deva ser administrada tão rápido quanto possível e, preferentemente, em dose única dentro dos cinco dias que sucedem a relação sexual (BRASIL, 2005c) 
Observamos na pesquisa ainda que a minoria não faz uso de nenhum método contraceptivo e um aluno não respondeu.

Considerando os que responderam negativamente a questão, dois alunos referiram não terem relação sexual no seu relacionamento atual e apenas um disse que não faz o uso de método contraceptivo "por puro descuido".

Analisando a Tabela 5, podemos considerar que, de maneira geral, a grande maioria dos graduandos em enfermagem faz uso de métodos contraceptivos que protegem contra as IST/aids (preservativo masculino) e também para evitar a gravidez (preservativo masculino e pílula anticoncepcional). No nosso estudo, nenhum universitário citou o uso do preservativo feminino.

A maior parte dos métodos contraceptivos utilizados pelos estudantes são comprados em farmácias; outros alunos obtém associando a farmácia e unidade básica de saúde ou com o médico, e somente cinco alunos não responderam esta questão.

Ao verificarmos o contraceptivo utilizado na primeira relação sexual (Tabela 4) e no relacionamento atual (Tabela 5) dos alunos da graduação em enfermagem, houve uma inversão em relação ao tipo de método contraceptivo utilizado, uma vez que, no início da vida sexual, o método escolhido foi o preservativo masculino, seguido da associação do preservativo masculino mais a pílula, e em terceiro lugar apenas o uso da pílula.

Já no relacionamento atual, podemos notar algumas mudanças de comportamento em relação à escolha do método contraceptivo: primeiramente, temos o uso do preservativo masculino associado à pílula anticoncepcional, seguido do uso apenas da pílula, e por fim o uso somente do preservativo masculino.

Essa mudança do tipo de contraceptivo utilizado está relacionada ao tipo de relacionamento que o sujeito está tendo no momento. Veremos durante os próximos dados da 
pesquisa que essa mudança de comportamento está diretamente relacionada a "confiança no parceiro(a)".

Tabela 6 - Distribuição numérica e percentual das respostas dos alunos de $1^{\circ}$ e $4^{\circ}$ ano em relação às questões: Você já deixou de fazer uso da camisinha em alguma relação sexual?, Se sim, por que? e Se não usou, por que? 2006

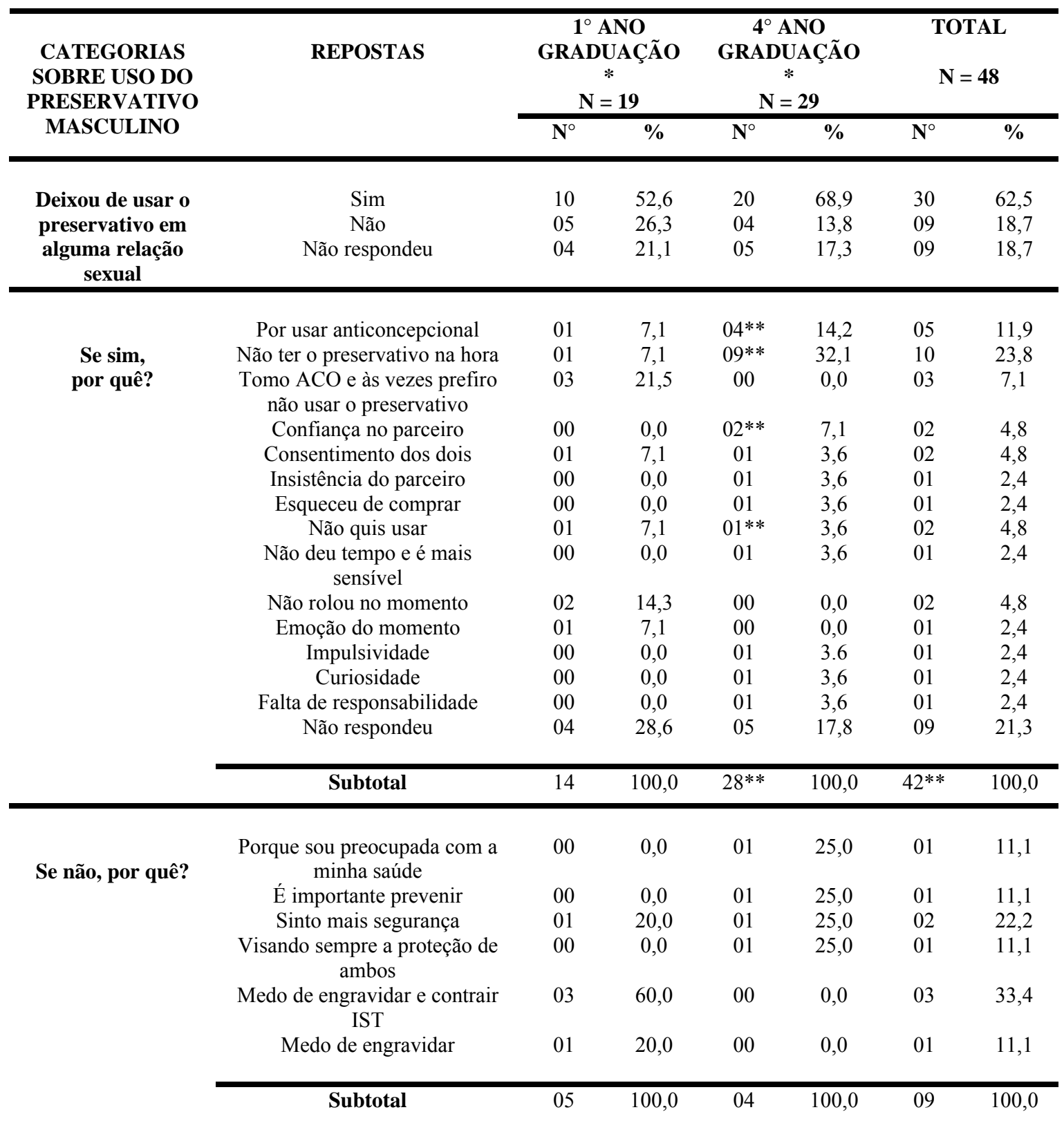

* Lembrando que no $1^{\circ}$ ano temos que 10 alunos não iniciaram a vida sexual e no $4^{\circ}$ ano 1 aluno não iniciou a vida sexual. **No $4^{\circ}$ ano observamos que 3 alunos tiveram duas respostas (Por usar anticoncepcional e não ter o preservativo na hora; Confiança no parceiro e não ter o preservativo na hora; Não quis usar e não ter o preservativo na hora) 
Como pode ser visto na Tabela 6 , mais da metade dos alunos $(62,5 \%)$ relataram já ter deixado de usar o preservativo em algum momento; já 18,7\% disseram que sempre fizeram uso desse método em todas as relações sexuais, e 18,7\% não responderam.

Em um estudo realizado com 1039 estudantes universitários, solteiros, de instituições particulares de ensino da Região da Grande São Paulo, concluiu-se que, em relação ao comportamento de risco, $56,2 \%$ dos homens e $56,4 \%$ das mulheres referem uso eventual do preservativo nas relações sexuais (GIL; TEMPORINI, 2000).

Pirotta (2002) relata em sua pesquisa que 57,2\% dos universitários entrevistados já haviam deixado de usar o preservativo em alguma relação sexual, enquanto $42,8 \%$ referiram nunca ter deixado de usá-lo.

Estudo realizado em 2004 constatou que 96\% da população brasileira sexualmente ativa têm conhecimento de que o preservativo protege da transmissão sexual do HIV, contudo, grande parte ainda não faz uso sistemático desse método (BRASIL, 2004).

Uma pesquisa realizada pelo Ministério da Saúde, em 2005, com 5040 pessoas de ambos os sexos, cujos resultados apresentados, inicialmente, são relativos à faixa etária entre 16 a 19 anos, mostrou que entre os homens o uso do preservativo passou de 45,1\%, em 1998, para $68,3 \%$ em 2005 , e de $44 \%$ para $57,5 \%$ na faixa etária de 20 a 24 anos; já nas mulheres, cresceu de $51 \%$ para $62,5 \%$, na faixa etária de 16 a 19 anos, no mesmo período; e de $30 \%$ para 52,4\% na faixa de 20 a 24 anos (BRASIL, 2005).

Abdo (2006), em seu estudo populacional com os brasileiros, constatou que $43,6 \%$ das mulheres e $34,9 \%$ dos homens nunca usaram o preservativo na relação sexual. A autora ressalta que esses dados vêm ao encontro do risco por excesso de confiança, timidez, permissividade, desinformação, descuido e perfil.

Observando a justificativa dos graduandos em enfermagem relacionada ao fato de ter deixado de usar o preservativo masculino, encontramos que a maior parte $(23,8 \%)$ não tinha o 
preservativo no momento da relação sexual, $11,9 \%$ faziam uso da pílula e 21,3\% não responderam essa pergunta.

Pesquisa realizada pelo Ministério da Saúde revela, ainda, que, entre os homens os principais motivos para não usar o preservativo, estão: a falta do preservativo no momento da relação sexual, a carência de informação e orientação e não pensar no assunto. Entre as mulheres, a confiança no parceiro é um dos principais motivos para não usar preservativo (BRASIL, 2005).

Bento (2000) encontrou que o uso do preservativo entre os universitários de uma universidade pública ainda não era totalmente praticado e que a prática do sexo oral estava sendo muito utilizada entre os alunos, chegando bem perto da prática vaginal.

Enquanto Bandeira e Diógenes (2006), em pesquisa com universitários da graduação em enfermagem, encontraram que $62,4 \%$ dos alunos relataram que não fazem uso do preservativo quando estão vivenciando um relacionamento estável, enquanto $15,1 \%$ não o utilizam fora do período fértil, evidenciando que neste caso o preservativo é considerado um método contraceptivo, e 9,4\% dos participantes afirmaram que não se protegem com o preservativo quando fazem sexo oral. Apenas 7,5\% informaram utilizar o preservativo em todas as relações sexuais.

Considerando os alunos da enfermagem que não deixaram de usar o preservativo masculino, suas afirmações foram: que o fizeram "por ter medo de engravidar ou contrair IST/aids"; em menor escala, responderam "por sentir mais segurança"; "por ser preocupado com a saúde"; "por causa da prevenção"; "para proteção de ambos”; e apenas um aluno "por medo de engravidar".

Ressaltamos que, entre os alunos do $1^{\circ}$ ano, $60 \%$ referiram o medo da gravidez e de contrair IST/aids. Entre os alunos do último ano, a questão da prevenção, a proteção do casal 
e a preocupação com a saúde foram as únicas justificativas apresentadas para o uso do preservativo em todas as relações sexuais.

Bandeira e Diógenes (2006) constataram que 88,7\% dos graduandos em enfermagem afirmam que o uso do preservativo masculino e feminino traz como vantagens a prevenção de IST/Aids e/ou gravidez.

Acreditamos ser necessário reforçar a importância do cuidado com a própria saúde e com a do parceiro, buscando diminuir o preconceito quanto à utilização desse método, até mesmo quando se tem um parceiro fixo, pois este não está livre de ser portador de uma IST.

Tabela 7 - Distribuição numérica e percentual das respostas dos de $1^{\circ}$ e $4^{\circ}$ ano segundo a questão: Quantos parceiros (as) sexuais você teve neste último ano? 2006

\begin{tabular}{|c|c|c|c|c|c|c|}
\hline \multirow{2}{*}{$\begin{array}{l}\text { CATEGORIAS SOBRE NÚMERO DE } \\
\text { PARCEIROS NO ÚLTIMO ANO } \\
\text { RESPOSTAS }\end{array}$} & \multicolumn{2}{|c|}{$\begin{array}{c}1^{\circ} \text { ANO } \\
\text { GRADUAÇÃO* } \\
\text { N }=19\end{array}$} & \multicolumn{2}{|c|}{$\begin{array}{c}4^{\circ} \text { ANO } \\
\text { GRADUAÇÃO* } \\
\text { N = } 29\end{array}$} & \multicolumn{2}{|c|}{$\begin{array}{l}\text { TOTAL } \\
\mathbf{N}=48\end{array}$} \\
\hline & $\mathbf{N}^{\circ}$ & $\%$ & $\mathbf{N}^{\circ}$ & $\%$ & $\mathbf{N}^{\circ}$ & $\%$ \\
\hline 01 & 11 & 57,9 & 18 & 62,0 & 29 & 60,4 \\
\hline 02 a 03 & 04 & 21,0 & 07 & 24,1 & 11 & 22,9 \\
\hline 04 a 05 & 02 & 10,5 & 02 & 6,9 & 04 & 8,3 \\
\hline$\geq 06$ & 01 & 5,3 & 01 & 3,5 & 02 & 4,2 \\
\hline Nenhum & 01 & 5,3 & 01 & 3,5 & 02 & 4,2 \\
\hline
\end{tabular}

* Lembrando que no $1^{\circ}$ ano temos que 10 alunos não iniciaram a vida sexual e no $4^{\circ}$ ano 1 aluno não iniciou a vida sexual.

Mais da metade dos estudantes, tanto do $1^{\circ}$ ano $(57,9 \%)$ quanto do $4^{\circ}$ ano $(62,0 \%)$, citou ter tido apenas um parceiro(a) sexual nesse último ano. Em menor escala, aparecem aqueles que disseram ter tido de 2 a 3 parceiros (as) sexuais, 8,3\% de 4 a 5, 4,2\% mais de 6 parceiros e 4,2\% referiram não ter tido nenhum parceiro sexual neste último ano.

Em relação ao número de parceiros sexuais durante a vida, Bandeira e Diógenes (2006) evidenciaram que, dos 50 alunos que mantinham relação sexual, 38 tiveram entre um a quatro parceiros sexuais e 12 tiveram acima de 5, até aquele momento. 
Em 12 meses, as brasileiras têm, em média 1,47 parceiro sexuais, enquanto os brasileiros têm 2,94 de parceiras (ABDO, 2006).

A partir dos nossos dados, podemos verificar que alguns dos alunos entrevistados podem estar expostos a agravos em relação a sua saúde sexual, correndo risco de adquirir IST/aids.

Tabela 8 - Distribuição numérica e percentual das respostas dos alunos de $1^{\circ}$ e $4^{\circ}$ ano em relação à questão: Você já adquiriu algum tipo de IST (Infecções Sexualmente Transmissíveis)? 2006

\begin{tabular}{|c|c|c|c|c|c|c|}
\hline $\begin{array}{l}\text { CATEGORIAS SOBRE SE JÁ } \\
\text { ADQUIRIU ALGUMA IST? }\end{array}$ & \multicolumn{2}{|c|}{$\begin{array}{c}1^{\circ} \text { ANO } \\
\text { GRADUAÇÃO } \\
* * \\
\mathbf{N}=19\end{array}$} & \multicolumn{2}{|c|}{$\begin{array}{c}4^{\circ} \text { ANO } \\
\text { GRADUAÇÃO } \\
* * \\
\mathbf{N}=\mathbf{2 9}\end{array}$} & \multicolumn{2}{|c|}{$\begin{array}{l}\text { TOTAL } \\
\mathbf{N}=48\end{array}$} \\
\hline RESPOSTAS & $\mathbf{N}^{\circ}$ & $\%$ & $\mathbf{N}^{\circ}$ & $\%$ & $\mathbf{N}^{\circ}$ & $\%$ \\
\hline $\operatorname{Sim}$ & 01 & 5,3 & 00 & 0,0 & 01 & 2,1 \\
\hline Não & 18 & 94,7 & 29 & 100,0 & 47 & 97,9 \\
\hline
\end{tabular}

* As questões 13 e 14 dizem respeito a qual doença e onde procurou tratamento, mas como apenas um aluno referiu ter tido IST, achamos melhor apenas relatar abaixo, ao invés de colocar na tabela 8.

** Lembrando que no $1^{\circ}$ ano temos que 10 alunos não iniciaram a vida sexual e no $4^{\circ}$ ano 1 aluno não iniciou a vida sexual.

Podemos observar na Tabela 8 que apenas um aluno do $1^{\circ}$ ano da graduação em enfermagem referiu ter adquirido IST. O aluno relata que não lembra o nome da doença e que procurou o serviço de saúde para realizar o tratamento.

Na nossa pesquisa, tivemos um número baixo de pessoas que já adquiriram alguma IST, enquanto Bandeira e Diógenes (2006) encontraram em sua pesquisa com alunos de enfermagem que $83,01 \%$ nunca foram acometidos por nenhuma IST, no entanto $17 \%$ com história pregressa/atual de IST, dos quais três tiveram HPV (Papilomavírus humano) e dois Herpes vírus tipo 2 e mais quatro foram acometidos por outras IST não especificadas.

As IST são responsáveis por $17 \%$ de perdas econômicas com o binômio saúde-doença no mundo, principalmente nos países que estão em desenvolvimento. Estudos realizados em 
vários países mostraram que pessoas com IST, mesmo não ulcerativas, aumentam o risco de se infectar pelo HIV de 3 a 10 vezes, dependendo do tipo e etiologia (BRASIL, 2005a).

Segundo o Boletim Epidemiológico de Aids e DST de janeiro a junho de 2006, no Brasil, desde a identificação do primeiro caso de aids, em 1980, até junho de 2006, já foram identificados cerca de 433 mil casos da doença. Até metade da década de 90, as taxas de incidência - número de casos novos de aids dividido pela população - foram crescentes, chegando a alcançar, em 1998, cerca de 19 casos de aids por 100 mil habitantes. Do total de casos, cerca de $80 \%$ estavam concentrados nas regiões Sudeste e Sul (BRASIL, 2006).

Mais recentemente, a taxa de incidência de aids mantém-se, ainda, em patamares elevados - em 18 casos por 100 mil habitantes - basicamente devido à persistência da tendência de crescimento entre as mulheres. Apresentou declínio em menores de 5 anos e no sexo masculino, com redução das taxas de incidência nas faixas etárias de 13 a 29 anos e crescimento nas faixas posteriores, principalmente a partir de 40 anos (BRASIL, 2006).

No mundo inteiro, as IST continuam atingindo milhões de pessoas. Segundo a OMS, o número é de 340 milhões de novos casos de IST curáveis (sífilis, tricomoníase, infecção pela clamídia e pelo gonococo). Os países em desenvolvimento concentram quase $80 \%$ dos casos. Complicações resultantes dessas doenças são potencialmente graves, envolvendo o risco de infertilidade, abortamento, natimortalidade e infecções congênitas, além de facilitar a infecção pelo HIV. Para o Brasil, a Organização Mundial de Saúde estima entre 10 a 12 milhões de casos novos de IST por ano (BRASIL, 2006). 
Tabela 9 - Distribuição numérica e percentual das respostas dos alunos de $1^{\circ}$ e $4^{\circ}$ ano em relação à questão: Classifique o grau de risco em adquirir alguma IST em cada tipo de relação sexual (sexo vaginal, oral, anal e com preservativo)? 2006

\begin{tabular}{|c|c|c|c|c|c|c|c|}
\hline \multirow{2}{*}{$\begin{array}{l}\text { CATEGORIAS } \\
\text { SOBRE TIPO } \\
\text { DE RELAÇÃO } \\
\text { SEXUAL }\end{array}$} & \multirow[t]{2}{*}{$\begin{array}{c}\text { GRAU } \\
\text { DE RISCO }\end{array}$} & \multicolumn{2}{|c|}{$\begin{array}{c}1^{\circ} \text { ANO } \\
\text { GRADUAÇÃO } \\
\text { N = } 29\end{array}$} & \multicolumn{2}{|c|}{$\begin{array}{c}4^{\circ} \text { ANO } \\
\text { GRADUAÇÃO } \\
\text { N = } 30\end{array}$} & \multicolumn{2}{|c|}{$\begin{array}{l}\text { TOTAL } \\
\mathbf{N}=59\end{array}$} \\
\hline & & $\mathbf{N}^{\circ}$ & $\%$ & $\mathbf{N}^{\circ}$ & $\%$ & $\mathbf{N}^{\circ}$ & $\%$ \\
\hline Sexo Vaginal & $\begin{array}{l}\text { Grande risco } \\
\text { Médio risco } \\
\text { Pequeno risco } \\
\text { Nenhum risco } \\
\text { Não responderam }\end{array}$ & $\begin{array}{l}21 \\
06 \\
02 \\
00 \\
00\end{array}$ & $\begin{array}{c}72,4 \\
20,7 \\
6,9 \\
0,0 \\
0,0\end{array}$ & $\begin{array}{l}24 \\
06 \\
00 \\
00 \\
00\end{array}$ & $\begin{array}{c}80,0 \\
20,0 \\
0,0 \\
0,0 \\
0,0\end{array}$ & $\begin{array}{l}45 \\
12 \\
02 \\
00 \\
00\end{array}$ & $\begin{array}{c}76,3 \\
20,3 \\
3,4 \\
0,0 \\
0,0\end{array}$ \\
\hline Sexo Oral & $\begin{array}{l}\text { Grande risco } \\
\text { Médio risco } \\
\text { Pequeno risco } \\
\text { Nenhum risco } \\
\text { Não responderam }\end{array}$ & $\begin{array}{l}17 \\
10 \\
02 \\
00 \\
00\end{array}$ & $\begin{array}{c}58,6 \\
34,5 \\
69 \\
0,0 \\
0,0\end{array}$ & $\begin{array}{l}13 \\
13 \\
04 \\
00 \\
00\end{array}$ & $\begin{array}{c}43,3 \\
43,3 \\
13,4 \\
0,0 \\
0,0\end{array}$ & $\begin{array}{l}30 \\
23 \\
06 \\
00 \\
00\end{array}$ & $\begin{array}{c}50,8 \\
39,0 \\
10,2 \\
0,0 \\
0,0\end{array}$ \\
\hline Sexo Anal & $\begin{array}{l}\text { Grande risco } \\
\text { Médio risco } \\
\text { Pequeno risco } \\
\text { Nenhum risco } \\
\text { Não responderam }\end{array}$ & $\begin{array}{l}27 \\
02 \\
00 \\
00 \\
00\end{array}$ & $\begin{array}{c}93,1 \\
6,9 \\
0,0 \\
0,0 \\
0,0\end{array}$ & $\begin{array}{l}22 \\
06 \\
02 \\
00 \\
00\end{array}$ & $\begin{array}{c}73,4 \\
20,0 \\
6,6 \\
0,0 \\
0,0\end{array}$ & $\begin{array}{l}49 \\
08 \\
02 \\
00 \\
00\end{array}$ & $\begin{array}{c}50,8 \\
39,0 \\
10,2 \\
0,0 \\
0,0\end{array}$ \\
\hline $\begin{array}{c}\text { Sexo com } \\
\text { preservativo } \\
\text { (durante toda a } \\
\text { relação sexual) }\end{array}$ & $\begin{array}{l}\text { Grande risco } \\
\text { Médio risco } \\
\text { Pequeno risco } \\
\text { Nenhum risco } \\
\text { Não responderam }\end{array}$ & $\begin{array}{l}00 \\
00 \\
14 \\
12 \\
03\end{array}$ & $\begin{array}{c}0,0 \\
0,0 \\
48,3 \\
41,4 \\
10,3\end{array}$ & $\begin{array}{l}00 \\
05 \\
13 \\
08 \\
04\end{array}$ & $\begin{array}{c}0,0 \\
16,8 \\
43,3 \\
26,6 \\
13,3\end{array}$ & $\begin{array}{l}00 \\
05 \\
27 \\
20 \\
07\end{array}$ & $\begin{array}{c}0,0 \\
8,5 \\
45,8 \\
33,9 \\
11,8\end{array}$ \\
\hline
\end{tabular}

$\mathrm{Na}$ Tabela 9, verificamos que, quanto ao sexo vaginal, tanto alunos do $1^{\circ}$ ano $(72,4 \%)$ quanto do $4^{\circ}$ ano $(80,0 \%)$ relataram ser de "grande risco" a chance de adquirir IST/aids.

Tanto no sexo oral quanto no sexo anal, 50,8\% dos alunos disseram ser de "grande risco", seguido de 39\% que acreditam ser de "médio risco".

Já no sexo com preservativo, encontramos que 45,8\% acreditam ser de "pequeno risco", $33,9 \%$ referem não ter "nenhum risco", $11,8 \%$ não responderam a pergunta e $8,5 \%$ relataram ser de "médio risco". 
Gostaríamos de ressaltar que foi especificado no instrumento preenchido pelos alunos que o sexo realizado com preservativo seria durante toda a relação sexual. Mesmo assim tivemos que $16,8 \%$ dos alunos do $4^{\circ}$ ano ainda acreditavam ser de "médio risco", 48,3\% e $43,3 \%\left(1^{\circ}\right.$ e $4^{\circ}$ ano, respectivamente) relataram "pequeno risco" e $41,4 \%$ e $26,6 \%\left(1^{\circ}\right.$ e $4^{\circ}$ ano respectivamente) realmente acreditavam na eficácia do preservativo com relação à prevenção às IST/aids.

No $1^{\circ}$ ano, $10,3 \%$ e no $4^{\circ}$ ano, $13,3 \%$ não responderam a questão.

Devemos ressaltar neste momento a questão do uso do preservativo masculino relacionado à prevenção às IST/aids. Carvalho (2003), em seu livro sobre o HPV (Papilomavírus humano) nos faz refletir sobre até que ponto o preservativo masculino confere proteção às IST/aids. O autor relata que a região que não está protegida pelo preservativo masculino pode servir de porta de entrada para o HPV e/ou Sífilis, por exemplo. Relata que há vários homens que usaram o preservativo e apresentavam verrugas e/ou feridas nas regiões escrotal, pubiana, inguinal e na base do pênis.

Já o preservativo feminino, por envolver mais amplamente a genitália feminina, parece fornecer mais proteção do que a masculina (CARVALHO, 2003). 
Quadro 1 - Distribuição das respostas dos 29 alunos do $1^{\circ}$ ano de graduação em enfermagem, em relação à pergunta: Como você analisa o seu comportamento sexual em relação ao risco de você adquirir alguma IST? 2006

\begin{tabular}{|c|c|}
\hline Sujeitos & $\begin{array}{l}\text { Analiso o meu comportamento sexual em relação ao risco de adquirir alguma } \\
\text { IST da seguinte forma: }\end{array}$ \\
\hline 1 & Considero que meu comportamento sexual acarrete poucas chances de adquirir IST. \\
\hline 2 & $\begin{array}{l}\text { Eu e meu namorado nos prevenimos, mas acredito que exista o risco. Ele é o meu único parceiro, e espero } \\
\text { ser a única dele também. }\end{array}$ \\
\hline 3 & Eu avalio que seja baixo, visto que tomo todas as medidas recomendadas. \\
\hline 4 & $\begin{array}{l}\text { Acho que o risco é pequeno, pois as relações que tive enquanto não namorava foram com preservativo. Mas } \\
\text { sei que apesar de confiar no meu atual namorado, eles podem não ter sido fiéis. }\end{array}$ \\
\hline 5 & $\begin{array}{l}\text { Ainda não iniciei a minha vida sexual, porém tenho consciência de que devo tomar o máximo de cuidado } \\
\text { para não haver riscos de adquirir IST. }\end{array}$ \\
\hline 6 & $\begin{array}{l}\text { Como ainda não iniciei a minha vida sexual acredito não correr nenhum risco, já que também não uso drogas } \\
\text { injetáveis. }\end{array}$ \\
\hline 7 & 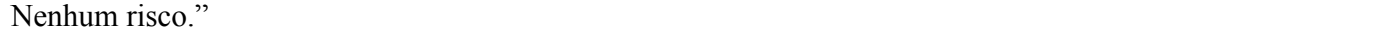 \\
\hline 8 & Nenhum risco, pois estou consciente de todos os meios de proteção e não me arriscaria a não usá-los. \\
\hline 9 & Pequeno risco. \\
\hline 10 & $\begin{array}{l}\text { Ainda não iniciei a minha vida sexual, porém tenho consciência de que devo tomar o máximo de cuidado } \\
\text { quando este momento chegar. }\end{array}$ \\
\hline 11 & Seguro. \\
\hline 12 & Dificilmente poderei adquirir alguma IST. \\
\hline 13 & Nenhum risco. \\
\hline 14 & Considero não estar correndo nenhum grande risco porque o máximo que faço é dar uns beijos e amassos. \\
\hline 15 & $\mathrm{Eu}$ acho que porque eu uso preservativo sempre o risco de adquirir IST é praticamente nulo. \\
\hline 16 & $\begin{array}{l}\text { Tenho pouco risco de pegar IST, pois sempre uso anticoncepcional e preservativo. } \mathrm{O} \text { acompanhamento com } \\
\text { uma ginecologista também acho importante. }\end{array}$ \\
\hline 17 & $\begin{array}{l}\text { Como ainda não iniciei a minha vida sexual, me previno de modo a não utilizar locais em que posso adquirir } \\
\text { doenças ou usar roupas íntimas de outras pessoas. }\end{array}$ \\
\hline 18 & Possuo risco já que não utilizo camisinha, porém só tenho um parceiro sexual. \\
\hline 19 & Nenhum risco. \\
\hline 20 & $\begin{array}{l}\text { Eu acredito que às vezes tenho falhado na prevenção, por confiar no namorado que regularmente faz exames, } \\
\text { mas deveria me prevenir melhor. }\end{array}$ \\
\hline 21 & Acho que sou consciente o suficiente para evitar IST, mantendo sempre a higiene adequada. \\
\hline 22 & Eu considero que o meu comportamento é seguro. Unico parceiro. \\
\hline 23 & Não respondeu. \\
\hline 24 & $\begin{array}{l}\text { Muito correto, pois tomo todos os cuidados necessários, como uso de preservativo. Mas peco no sexo oral } \\
\text { pois não uso proteção. }\end{array}$ \\
\hline 25 & Eu acho que tenho informações suficientes para prevenir essas doenças, então acho que os riscos são baixos. \\
\hline 26 & $\begin{array}{l}\text { Eu tenho apenas um parceiro desde quando iniciei a minha vida sexual, mas mesmo assim sei que existem } \\
\text { riscos, caso ele mantenha relações com outra pessoa. }\end{array}$ \\
\hline 27 & Me previno bem, além de trocar informações e experiências com amigos e parceiros. \\
\hline 28 & Tenho consciência que posso adquirir uma IST, mas já transei sem camisinha. \\
\hline 29 & Não é seguro nem responsável. \\
\hline
\end{tabular}

\section{Categorização sobre a análise do comportamento sexual dos alunos do $1^{\circ}$ ano em relação ao risco de adquirir alguma IST.}

- Comportamento sexual seguro e/ou baixo risco (S: 1, 3, 4, 5, 6, 7, 8, 9, 10, 11, 12, 13, 14, 15, 16, 17, $19,21,22,24,25,27)$

- Confiança no parceiro (a) (S: 2, 4, 18, 20, 22, 26);

- Não faz uso sistemático do preservativo (S: 18, 20, 24, 26, 28, 29);

- Comportamento de risco (S: 2, 18, 26, 29);

- $\quad$ Falta de informação correta (S: 16, 17, 21);

- Uso de anticoncepcional (S: 16);

- Não respondeu (S: 23). 
Para melhor análise e visualização dos dados, optamos por fazer as discussões dos

Quadros 1 e 2 após a categorização do Quadro 2.

Quadro 2 - Distribuição das respostas dos 30 alunos do $4^{\circ}$ ano de graduação em enfermagem, em relação à pergunta: Como você analisa o seu comportamento sexual em relação ao risco de você adquirir alguma IST? 2006.

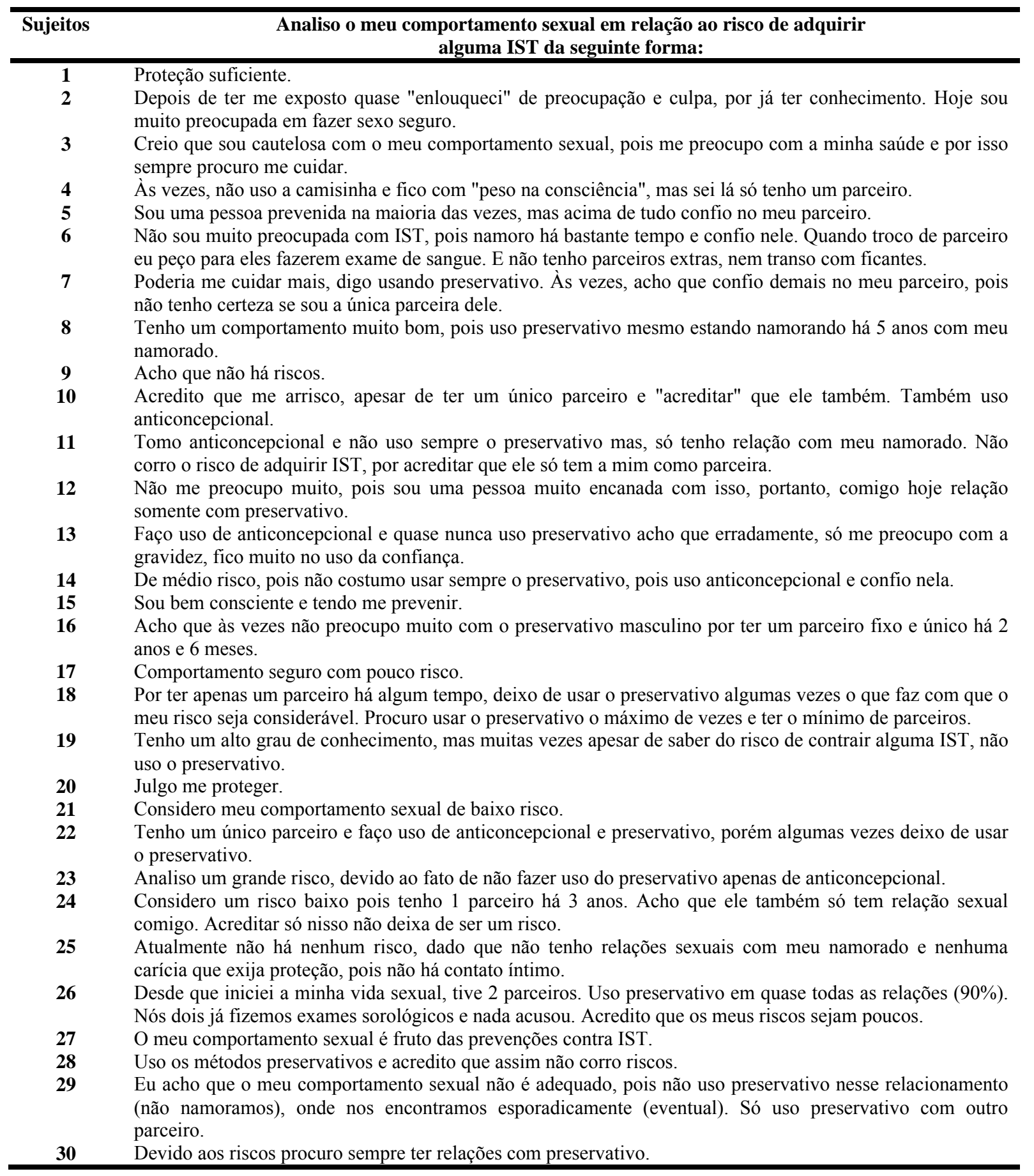




\section{Categorização sobre a análise do comportamento sexual dos alunos do $4^{\circ}$ ano em relação ao risco de adquirir alguma IST.}

- Comportamento sexual seguro e/ou baixo risco (S: 1, 2, 3, 8, 9, 12, 15, 17, 20, 21, 25, 27, 28, 30);

- Confiança no parceiro (a) (S: 4, 5, 6, 7, 10, 11, 13, 14, 16, 18, 22, 24, 26);

- Não faz uso sistemático do preservativo (S: 4, 7, 11, 13, 14, 16, 18, 19, 22, 23, 26, 29);

- Comportamento de risco (S: 6, 10, 14, 18, 23, 29);

- Uso de anticoncepcional (S: 10, 11, 13, 14, 22, 23).

Ao analisarmos o comportamento sexual dos alunos do primeiro e quarto ano, percebemos algumas diferenças marcantes, certamente relacionadas ao tipo de relacionamento afetivo dos alunos.

Pela Tabela 2, vimos que $70 \%$ dos alunos do último ano estavam namorando no momento em que responderam o questionário, enquanto apenas $48,3 \%$ dos alunos iniciantes mantinham o mesmo tipo de relacionamento, fato que nos justifica a diferente análise do comportamento sexual feita pelos sujeitos pesquisados.

Em relação à categoria comportamento sexual seguro e/ou baixo risco, podemos verificar que 22 sujeitos do $1^{\circ}$ ano referiram ter esse comportamento, enquanto do último ano tivemos 14 sujeitos.

Mas devemos ressaltar que, dentre os alunos que começaram a faculdade, 10 não iniciaram a vida sexual, sendo que 9 estão entre os sujeitos citados na categoria comportamento seguro e/ou baixo e risco e 1 sujeito não respondeu. Já no $4^{\circ}$ ano, um aluno não iniciou a vida sexual.

Dessa maneira, se excluíssemos os alunos que não tiveram relação sexual, ou seja, com comportamento seguro, nós teríamos 13 sujeitos tanto do $1^{\circ}$ quanto do $4^{\circ}$ ano.

Podemos verificar, através das respostas dos sujeitos, porque ele acredita que seu comportamento sexual seja seguro. 


\section{$1^{\circ}$ ano}

"Ainda não iniciei a minha vida sexual, porém tenho consciência de que devo tomar o máximo de cuidado para não haver riscos de adquirir IST.” (S: 5)*

"Como ainda não iniciei a minha vida sexual acredito não correr nenhum risco, já que também não uso drogas injetáveis." (S: 6)

"Nenhum risco, pois estou consciente de todos os meios de proteção e não me arriscaria a não usá-los.” (S: 8)

"Ainda não iniciei a minha vida sexual, porém tenho consciência de que devo tomar o máximo de cuidado quando este momento chegar." (S: 10)

"Considero não estar correndo nenhum grande risco porque o máximo que faço é dar uns beijos e amassos." (S: 14)

\section{$4^{\circ}$ ano}

“Acho que não há riscos.” (S: 9)

“Atualmente não há nenhum risco, dado que não tenho relações sexuais com meu namorado e nenhuma carícia que exija proteção, pois não há contato íntimo.” (S: 25)

"Uso os métodos preservativos e acredito que assim não corro riscos." (S: 28)

Podemos verificar nas respostas dos sujeitos abaixo as palavras "pouco" e "baixo risco", as quais nos fazem refletir sobre a questão da vulnerabilidade.

\section{$1^{\circ}$ ano}

"Considero que meu comportamento sexual acarrete poucas chances de adquirir IST." (S: 1)

"Eu acho que tenho informações suficientes para prevenir essas doenças, então acho que os riscos são baixos.” (S: 25)

\section{$4^{\circ}$ ano}

“Comportamento seguro com pouco risco." (S: 17)

"Considero meu comportamento sexual de baixo risco." (S: 21)

\footnotetext{
${ }^{*} \mathrm{~S}$ - significa sujeito, o qual poderá ser encontrado no respectivo quadro que está sendo analisado.
} 
Oliveira e Weinstein (2002) relatam que os fatores de risco estão diretamente relacionados a problemas estruturais subjetivos e objetivos que tornam a população em geral mais exposta as IST/aids, tais como a pobreza, a violência, a baixa escolaridade, iniqüidade de gênero, a falta de acesso aos serviços de saúde, entre outros. É a partir dessa nova concepção que a noção de vulnerabilidade vem sendo utilizada no sentido de aperfeiçoar estratégias de prevenção às IST/aids.

A vulnerabilidade não se limita apenas a identificar aqueles que têm alguma chance de se expor a uma IST/aids, mas favorece elementos para avaliar objetivamente as diversas possibilidades que qualquer pessoa tem de se contaminar, considerando certas características individuais e sociais que possam estar diretamente associadas a maior exposição e menor chance de proteção diante das doenças (AYRES, 1996).

Quando falamos na falta de informação, baixa escolaridade, além da falta de acesso aos meios de comunicação, serviços de saúde e aos meios de prevenção, estamos nos referindo à vulnerabilidade social, que também é responsável pelo maior ou menor risco de adquirir IST/aids (BRASIL b, 2005). Diante disso, apresentamos abaixo a reposta de um sujeito que refere adquirir informações.

\section{$1^{\circ}$ ano}

“Me previno bem, além de trocar informações e experiências com amigos e parceiros.” (S: 27)

Em relação ao preservativo, Gir, Duarte e Carvalho (1997) revelam que estudos comprovam a efetividade do uso do preservativo tanto como contraceptivo como profilático contra IST. Portanto, estamos vivendo uma fase bastante conflitante em termos de comportamento sexual, uma vez que o HIV se encontra em franca disseminação e a transmissão sexual se constitui a mais importante via de transmissão deste vírus no mundo.

Desse modo, a relação sexual com preservativo é considerada uma das medidas mais 
seguras para se evitar IST e gravidez, desde que o seu uso seja feito de forma correta e sistemática.

Algumas respostas dos alunos abordaram o uso do preservativo como meio de proteção às IST/aids:

$1^{\circ}$ ano

"Eu acho que porque eu uso preservativo sempre o risco de adquirir IST é praticamente nulo." (S: 15)

$4^{\circ}$ ano

"Tenho um comportamento muito bom, pois uso preservativo mesmo estando namorando há 5 anos com meu namorado." (S: 8)

"O meu comportamento sexual é fruto das prevenções contra IST." (S: 27)

"Devido aos riscos procuro sempre ter relações com preservativo." (S: 30)

No que diz respeito à categoria confiança no parceiro, os sujeitos que estão finalizando a graduação citaram o dobro de vezes essa categoria em relação aos alunos iniciantes.

Isso vem ao encontro da realidade dos sujeitos, como já foi citado anteriormente, pois a maioria dos alunos do $4^{\circ}$ ano mantém relacionamentos estáveis, enquanto no $1^{\circ}$ ano aproximadamente 50\% não estão namorando e mantém relacionamentos esporádicos (Tabela 2).

A confiança entre os pares, a questão do único parceiro, concordância em realizar exames sorológicos e apenas o uso do anticoncepcional para proteger somente a gravidez, fazem que deixem de usar preservativo, como pode ser visto nas respostas abaixo. 


\section{$1^{\circ}$ ano}

"Eu e meu namorado nos prevenimos, mas acredito que exista o risco. Ele é o meu único parceiro, e espero ser a única dele também.” (S: 2)

"Possuo risco já que não utilizo camisinha, porém só tenho um parceiro sexual." (S: 18)

"Eu acredito que às vezes tenho falhado na prevenção, por confiar no namorado que regularmente faz exames, mas deveria me prevenir melhor.” (S: 20)

\section{$4^{\circ}$ ano}

“Sou uma pessoa prevenida na maioria das vezes, mas acima de tudo confio no meu parceiro." (S: 5)

"Não sou muito preocupada com IST, pois namoro há bastante tempo e confio nele. Quando troco de parceiro eu peço para eles fazerem exame de sangue. E não tenho parceiros extras, nem transo com ficantes." (S: 6)

"De médio risco, pois não costumo usar sempre o preservativo, pois uso anticoncepcional e confio nela." (S:14)

"Desde que iniciei a minha vida sexual, tive 2 parceiros. Uso preservativo em quase todas as relações $(90 \%)$. Nós dois já fizemos exames sorológicos e nada acusou. Acredito que os meus riscos sejam poucos." (S: 26$)$

Frente ao exposto, acreditamos que os sujeitos passam a ter confiança no seu parceiro e, após algum tempo de relacionamento, deixam para traz princípios e práticas sexuais mais seguras, como pode ser observado entre os alunos do último ano, os quais mantêm um relacionamento mais estável.

Abdo (2004) refere que o principal motivo para não usar o preservativo é a confiança no parceiro (a). No seu estudo, ela encontrou que isso ocorre com $80 \%$ das mulheres e $70 \%$ dos homens, pois confiam que seus relacionamentos sejam exclusivos para ambos.

Levando em consideração os dados encontrados por Abdo, temos o fato de as mulheres, por influência cultural, possuem menor poder de convencimento que o homem. Para Bandeira e Diógenes (2006, p. 77) “a vulnerabilidade feminina é fortemente definida por 
um tipo de relação que a mulher mantém com a sua sexualidade e consigo mesma, cuja marca tem sido a subordinação ao desejo masculino".

Dessa maneira, acreditamos que a confiança e a subordinação entre os pares está diretamente relacionada com o não uso do preservativo.

Verificando a categoria não faz uso sistemático do preservativo, podemos averiguar que, os sujeitos que não usam sempre o preservativo, a maioria está entre os alunos do último ano da faculdade, fato já justificado devido ao maior número de relacionamentos estáveis entre os alunos do $4^{\circ}$ ano.

Como os alunos iniciantes mantêm relacionamentos esporádicos, em que na maioria das vezes ainda não houve o "pacto da confiança", esses sujeitos optam por não deixar de usar o preservativo.

Bandeira e Diógenes (2006) apontam que o momento que os estudantes de enfermagem mais temem por não usar o preservativo é quando conhecem o parceiro sexual há pouco tempo.

Algumas respostas que nos mostram o não uso sistemático do preservativo:

$1^{\circ}$ ano

"Muito correto, pois tomo todos os cuidados necessários, como uso de preservativo. Mas peco no sexo oral, pois não uso proteção.” (S: 24)

"Tenho consciência que posso adquirir uma IST, mas já transei sem camisinha." (S: 28)

"Não é seguro nem responsável." (S: 29)

$4^{\circ}$ ano

"Poderia me cuidar mais, digo usando preservativo. Às vezes, acho que confio demais no meu parceiro, pois não tenho certeza se sou a única parceira dele.” (S: 7)

"Acho que às vezes não preocupo muito com o preservativo masculino por ter um parceiro fixo e único há 2 anos e 6 meses." (S: 16) 
"Por ter apenas um parceiro há algum tempo, deixo de usar o preservativo algumas vezes o que faz com que o meu risco seja considerável. Procuro usar o preservativo o máximo de vezes e ter o mínimo de parceiros.” (S: 18)

"Tenho um alto grau de conhecimento, mas muitas vezes apesar de saber do risco de contrair alguma IST, não uso o preservativo." (S: 19)

Historicamente o uso do preservativo esteve associado a prostituição, promiscuidade e relações extra-conjugais. Diante disso, o uso do preservativo, tanto pelo homem quanto pela mulher, passou a acarretar um difícil acordo interpessoal, resultando em embaraço e desconfiança (GIR; NOGUEIRA; PELÁ, 1997).

A baixa freqüência do uso do preservativo torna esses sujeitos entrevistados mais vulneráveis a adquirir IST/aids. No Brasil, as ações desenvolvidas para a prevenção das IST/aids e a promoção da saúde primam pela recomendação do uso do preservativo em todas as relações sexuais, abordagens que recomendam a diminuição do número de parceiros, a abstinência e a fidelidade não têm tido impacto entre as pessoas sexualmente ativas (BRASIL, 2005b).

$\mathrm{Na}$ categoria uso do anticoncepcional, alguns sujeitos, a grande maioria do último ano, apontaram que fazem uso da pílula anticoncepcional isoladamente ou em associação com o preservativo, enquanto apenas um sujeito do $1^{\circ}$ ano referiu fazer uso dessa associação.

Algumas respostas dos sujeitos que apontaram o uso do anticoncepcional estão abaixo transcritas:

$1^{\circ}$ ano

“Tenho pouco risco de pegar IST, pois sempre uso anticoncepcional e preservativo. O acompanhamento com uma ginecologista também acho importante.” (S: 16) 


\section{$4^{\circ}$ ano}

"Tomo anticoncepcional e não uso sempre o preservativo mas, só tenho relação com meu namorado. Não corro o risco de adquirir IST, por acreditar que ele só tem a mim como parceira." (S: 11)

"Tenho um único parceiro e faço uso de anticoncepcional e preservativo, porém algumas vezes deixo de usar o preservativo." (S: 22)

Diante das respostas citadas acima, podemos verificar que há uma substituição de métodos contraceptivos. Sabemos que o preservativo usado de forma constante e correta é considerado um método eficaz na prevenção às IST/aids e gravidez (BANDEIRA e DIÓGENES, 2006).

Já a pílula anticoncepcional tem sua função relacionada a prevenir especificamente a gravidez. Uma das acadêmicas do $4^{\circ}$ ano respondeu:

"Faço uso de anticoncepcional e quase nunca uso preservativo acho que erradamente, só me preocupo com a gravidez, fico muito no uso da confiança." (S: 13)

Pelo depoimento desta aluna, constatamos que a sua preocupação é evitar a gravidez, dessa maneira ficando vulnerável às IST/aids.

Com a categoria comportamento de risco, conseguimos selecionar alguns sujeitos que têm consciência de que estão vulneráveis às IST/aids e até provavelmente a uma gravidez, mas, mesmo apresentando esse conhecimento, eles ainda mantêm situações de risco.

Algumas respostas dos sujeitos:

$1^{\circ}$ ano

“Não é seguro nem responsável.” (S: 29) 


\section{$4^{\circ}$ ano}

"Acredito que me arrisco, apesar de ter um único parceiro e "acreditar" que ele também. Também uso anticoncepcional.” (S:10)

"Analiso um grande risco, devido ao fato de não fazer uso do preservativo apenas de anticoncepcional." (S:23)

"Eu acho que o meu comportamento sexual não é adequado, pois não uso preservativo nesse relacionamento (não namoramos), onde nos encontramos esporadicamente (eventual). Só uso preservativo com outro parceiro." (S: 29)

Bandeira e Diógenes (2006) acreditam quem seja necessário a criação de programas de educação em saúde em que se inclua a prevenção às IST/aids, para que os jovens tenham oportunidade de reflexão e percebam, assim, que estão em situação de risco.

A categoria falta de informação apareceu apenas entre os alunos que estão iniciando a graduação em enfermagem.

Algumas respostas das iniciantes:

"Como ainda não iniciei a minha vida sexual, me previno de modo a não utilizar locais em que posso adquirir doenças ou usar roupas íntimas de outras pessoas.” (S:17)

"Acho que sou consciente o suficiente para evitar IST, mantendo sempre a higiene adequada." $(\mathrm{S}: 21)$

Diante das respostas, podemos verificar a falta de conhecimento desses sujeitos em relação ao modo de transmissão das IST/aids. 
- Conhecimento prévio sobre sexualidade e prevenção às IST/aids, antes de ingressar à faculdade.

Tabela 10 - Distribuição numérica das respostas dos alunos de $1^{\circ}$ e $4^{\circ}$ ano, em relação à questão: Durante sua vida, como foi que você adquiriu informações sobre sexualidade e às IST? 2006

\begin{tabular}{cccc}
\hline $\begin{array}{c}\text { CATEGORIAS REFERENTES A } \\
\text { ONDE ADQUIRIU INFORMAÇÕES } \\
\text { SOBRE SEXUALIDADE E IST? }\end{array}$ & $\begin{array}{c}\mathbf{1}^{\circ} \text { ANO } \\
\text { GRADUAÇÃo }\end{array}$ & $\begin{array}{c}\mathbf{4}^{\circ} \text { ANO } \\
\text { GRADUAÇÃo }\end{array}$ & TOTAL \\
\cline { 2 - 4 } RESPOSTAS* & & & \\
\hline Família & $\mathbf{N}^{\circ}=\mathbf{2 9}$ & 13 & $\mathbf{N}^{\circ}=\mathbf{3 0}$ \\
Escola & 13 & 22 & 46 \\
Amigos & 24 & 18 & 26 \\
Meios de comunicação & 08 & 23 & 44 \\
\hline
\end{tabular}

* Houve mais de uma resposta para alguns sujeitos.

$\mathrm{Na}$ Tabela 10, percebemos que a grande maioria dos alunos pesquisados refere ter adquirido informações sobre sexualidade e IST/aids por meio da escola e dos meios de comunicação. Esse dado nos reforça a importância do meio escolar, um local fundamental para trabalhar conhecimentos, habilidades e mudanças de comportamento. Assim, a escola representa um contexto propício e adequado para o desenvolvimento de ações educativas sobre sexualidade e IST/aids (OLIVEIRA; BUENO, 1997).

Da mesma forma, depreendemos que os meios de comunicação de massa também têm poder significativo como meio de divulgação desses assuntos. Todavia, nem sempre as mensagens veiculadas na mídia são adequadas, demandando reflexão neste sentido (BUENO, 2001). Em menor escala, aparecem outras formas de informação advindas da família e amigos. 
Tabela 11 - Distribuição numérica e percentual das respostas dos alunos de $1^{\circ}$ e $4^{\circ}$ ano, em relação à questão: Antes de você ingressar na faculdade qual era o seu grau de conhecimento sobre a prevenção das IST/aids? 2006.

\begin{tabular}{|c|c|c|c|c|c|c|}
\hline \multirow{2}{*}{$\begin{array}{l}\text { CATEGORIAS REFERENTES AO } \\
\text { GRAU DE CONHECIMENTO SOBRE } \\
\text { A PREVENÇÃO DAS IST/AIDS } \\
\text { RESPOSTAS }\end{array}$} & \multicolumn{2}{|c|}{$\begin{array}{c}1^{\circ} \text { ANO } \\
\text { GRADUAÇÃO } \\
\mathbf{N}=29\end{array}$} & \multicolumn{2}{|c|}{$\begin{array}{c}4^{\circ} \text { ANO } \\
\text { GRADUAÇÃo } \\
\text { N }=30\end{array}$} & \multicolumn{2}{|c|}{$\begin{array}{l}\text { TOTAL } \\
\mathrm{N}=59\end{array}$} \\
\hline & $\mathbf{N}^{\circ}$ & $\%$ & $\mathbf{N}^{\circ}$ & $\%$ & $\mathbf{N}^{\circ}$ & $\%$ \\
\hline $\begin{array}{l}\text { Nenhum conhecimento } \\
\text { Pouco conhecimento } \\
\text { Conhecimento suficiente }\end{array}$ & $\begin{array}{l}00 \\
01 \\
28\end{array}$ & $\begin{array}{r}0,0 \\
3,5 \\
96,5\end{array}$ & $\begin{array}{l}00 \\
06 \\
24\end{array}$ & $\begin{array}{c}0,0 \\
20,0 \\
80,0\end{array}$ & $\begin{array}{l}00 \\
07 \\
52\end{array}$ & $\begin{array}{r}0,0 \\
11,9 \\
88,1\end{array}$ \\
\hline
\end{tabular}

Relacionado ao grau de conhecimento sobre a prevenção das IST/aids, antes de ingressarem na faculdade, verificamos na Tabela 11 que tivemos uma alta freqüência de estudantes $\left(96,5 \%\right.$ e $80,0 \%$ do $1^{\circ}$ e $4^{\circ}$ ano respectivamente) referindo ter conhecimento suficiente para se proteger das IST/aids. Apenas a minoria dos alunos $\left(1^{\circ}\right.$ e $4^{\circ}$ ano $)$ relata ter chegado até a faculdade com pouco conhecimento sobre esta questão.

Lembramos que, mesmo com um grande número de alunos dizendo que antes de ingressar na faculdade já possuíam conhecimento para se prevenir contra as IST/aids, temos na Tabela 6 (citada anteriormente) que $62,5 \%$ dos alunos não fazem uso do preservativo em todas as relações sexuais, ou seja, mesmo o aluno referindo ter informações/conhecimento sobre o meio de prevenção, eles ainda continuam sendo vulneráveis a aquisição de alguma IST/aids.

No caso, devemos questionar: "Como foi a informação/conhecimento adquirido por esses jovens?", "Porque o estudante, mesmo tendo conhecimento, ainda é um agente vulnerável à IST/aids?”.

Diante dessas questões, encontramos na dissertação de Carvalho (1992) a definição de educação em saúde feita por Green (1980, p.6)

“é um processo que liga a lacuna entre a informação de saúde e a prática de saúde. A educação em saúde motiva a pessoa a tomar a informação e fazer alguma com ela, manter-se ele próprio mais saudável, evitando ações que sejam nocivas e formando hábitos que sejam benéficos." 
Carvalho (1992, p.18) ressalta que "o princípio da Educação em Saúde é que o comportamento em saúde deve ser voluntário.”

Para a autora acima

\begin{abstract}
"Saúde tem diferentes significados para pessoas diferentes, serve a diferentes propósitos para pessoas diferentes e é mais ou menos importante para diferentes pessoas. É por isso que não se pode justificar a imposição de critérios rígidos de comportamento de saúde adequado, a menos que a saúde de outros esteja ameaçada.” (CARVALHO, 1992, p.19)
\end{abstract}

Também encontramos Souza (1997) que estudou o comportamento dos portadores de HIV/Aids utilizando o Modelo de Crenças em Saúde.

Rosenstock (1966 apud Souza, 1997) propôs o Modelo de Crenças em Saúde, que é utilizado para melhor se compreender os fatores que influenciam na percepção e as crenças das pessoas para se poder planejar mais efetivamente os cuidados para manutenção ou reobtenção da saúde. Souza (1997) relata que, em saúde, tomar decisão é um processo no qual o indivíduo atravessa uma série de estágios ou fases. Interações com pessoas ou eventos em cada um desses estágios influenciam o indivíduo na tomada de decisão para sua saúde.

Estas considerações são baseadas no Modelo de Crenças em Saúde desenvolvido por Rosenstock (1974 apud Souza, 1997) e, segundo este modelo, para que uma pessoa emita comportamentos preventivos em relação a uma dada doença, ela deve ter as crenças:

- de que é suscetível à doença;

- de que a ocorrência da doença tem pelo menos moderada severidade e de que interfere em algum componente de sua vida;

- de que, se ela tomar uma ação particular, ser-lhe-á benéfico. Pode acreditar em alguma esperança ou cura. 


\section{- Dados sobre o papel da graduação na formação do aluno sobre sexualidade e IST/aids.}

Quadro 3 - Distribuição das respostas dos 29 alunos do $\mathbf{1}^{\circ}$ ano da graduação em enfermagem, em relação à pergunta: $\mathrm{O}$ que você espera que a graduação em enfermagem lhe ofereça de conhecimento sobre a temática sexualidade e IST/aids? 2006

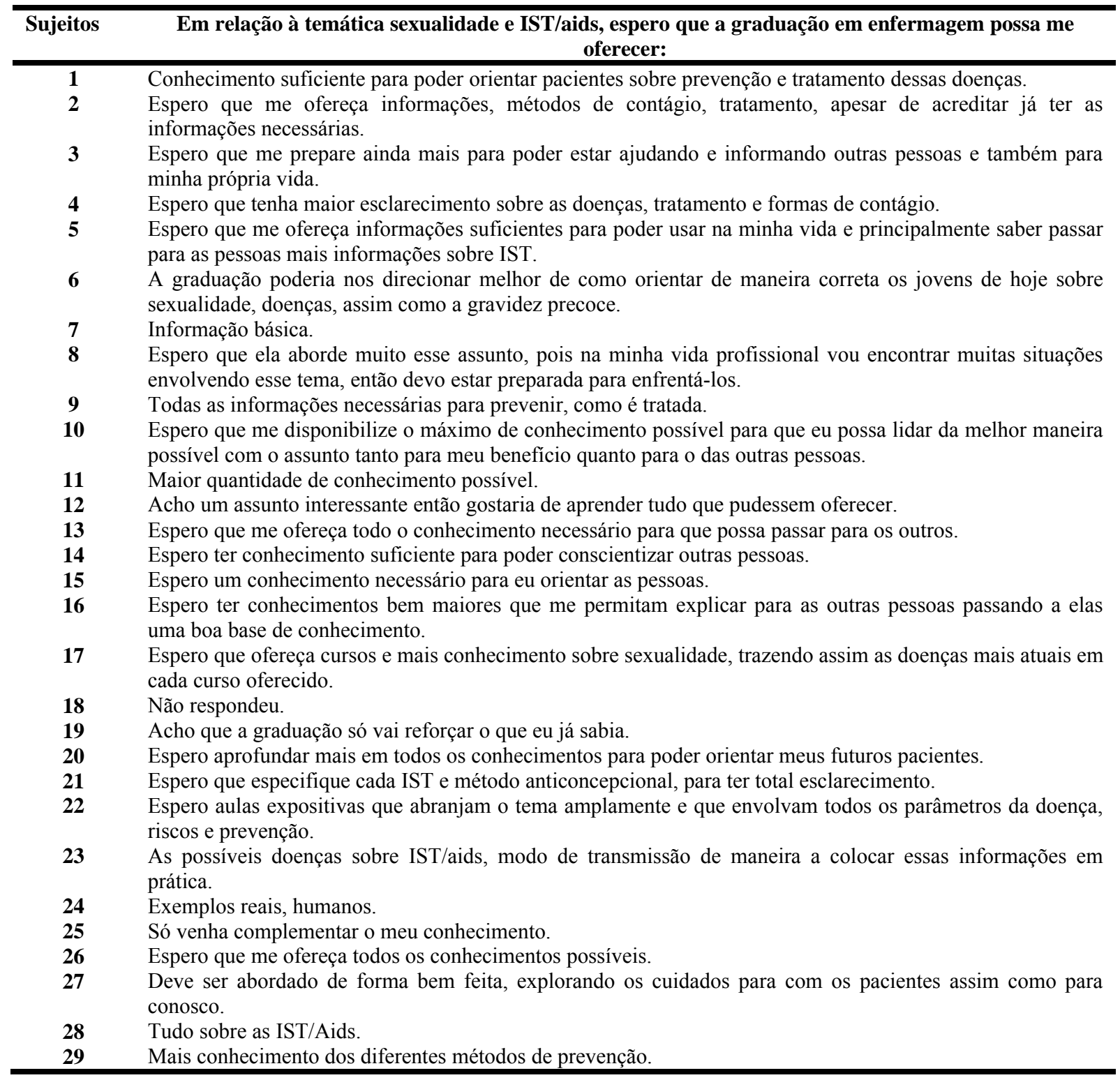

\section{Categorização sobre as expectativas dos alunos do $1^{\circ}$ ano em relação ao conhecimento sobre sexualidade e IST/aids.}

- Adquirir conhecimento (S: 1, 2, 4, 5, 7, 9, 10, 11, 12, 13, 14, 15, 16, 17, 20, 21, 22, 23, 25, 26, 29);

- Conhecimento para poder ajudar os outros (S: 1, 3, 5, 6, 8, 10, 13, 14, 15, 16, 20, 23, 27);

- Conhecimento sobre IST/aids e métodos contraceptivos (S: 1, 2, 4, 5, 6, 9, 17, 21, 22, 23, 28, 29);

- Conhecimento para sua própria vida (S: 3, 5, 10, 27);

- Conhecimento para reforçar o que já sabia (S: 2, 3, 19, 25);

- Conhecimento sobre sexualidade (S: 6, 17);

- Não respondeu (S: 18, 24). 
$\mathrm{Na}$ categoria adquirir conhecimento, a maioria dos sujeitos (21) espera receber da graduação em enfermagem mais conhecimento/informação/esclarecimento.

Algumas respostas dos sujeitos:

"Espero que tenha maior esclarecimento sobre as doenças, tratamento e formas de contágio." $(\mathrm{S}: 4)$

"Informação básica." (S:7)

"Maior quantidade de conhecimento possível." (S:11)

"Acho um assunto interessante então gostaria de aprender tudo que pudessem oferecer." $(\mathrm{S}: 12)$

"Espero que me ofereça todos os conhecimentos possíveis." (S:26)

Em relação às respostas acima, podemos verificar o quanto os alunos do $1^{\circ}$ ano estão abertos e dispostos a adquirir conhecimento sobre a temática em apreço.

Freire (1996) nos revela que a melhor maneira de se obter a educação é aprendê-la criticamente, sendo que essas condições implicam e exigem a presença de educadores e de educandos criadores, inquietos, rigorosamente curiosos, humildes e persistentes.

Ao observarmos a categoria conhecimento para ajudar os outros, podemos notar também a grande preocupação de 13 sujeitos em relação a ter conhecimento científico para trabalhar com seus pacientes.

Respostas de alguns acadêmicos iniciantes:

"Conhecimento suficiente para poder orientar pacientes sobre prevenção e tratamento dessas doenças." (S: 1)

“A graduação poderia nos direcionar melhor de como orientar de maneira correta os jovens de hoje sobre sexualidade, doenças, assim como a gravidez precoce.” (S: 6)

"Espero que ela aborde muito esse assunto, pois na minha vida profissional vou encontrar muitas situações envolvendo esse tema, então devo estar preparada para enfrentá-los.” (S: 8)

"Espero aprofundar mais em todos os conhecimentos para poder orientar meus futuros pacientes." (S: 20) 
As respostas acima nos mostram o comprometimento do aluno de graduação em enfermagem em relação aos seus futuros pacientes.

Gir, Nogueira e Pelá (2000) referem que a aquisição de conhecimentos sobre a temática sexualidade e IST/aids durante a graduação contribui para a minimização de posturas indevidas e inadequadas quando o aluno se depara com a temática em estudo e seu paciente.

A categoria conhecimento sobre IST/aids e métodos contraceptivos nos aponta 12 sujeitos preocupados em obter informações sobre modo de transmissão, prevenção e tratamento das IST.

Resposta de alguns alunos:

“Espero que me ofereça informações, métodos de contágio, tratamento, apesar de acreditar já ter as informações necessárias." (S: 2)

"Espero que especifique cada IST e método anticoncepcional, para ter total esclarecimento." $(\mathrm{S}: 21)$

"Espero aulas expositivas que abranjam o tema amplamente e que envolvam todos os parâmetros da doença, riscos e prevenção.” (S:22)

"As possíveis doenças sobre IST/aids, modo de transmissão de maneira a colocar essas informações em prática." (S:23)

Percebe-se que há entre os alunos uma grande necessidade de conhecimento sobre as IST, não tanto sobre sexualidade humana, e isso vem ao encontro da realidade dos cursos de enfermagem.

Ramin e Soler (2002), investigando alguns aspectos referentes à formação do enfermeiro em relação à sexualidade humana, verificaram que durante a graduação são enfatizados os aspectos anatômicos e fisiológicos, enquanto "pincelam" informações sobre sexualidade. 
Não temos dúvida de que é mais confortável ao profissional de saúde fazer um diagnóstico de IST do que "parar" e "ouvir" queixas de seus pacientes a respeito de falta de desejo, orientação sexual, dispareunia, entre outros assuntos mais subjetivos.

Todavia, averiguando as respostas dos nossos sujeitos, encontramos que apenas dois alunos abordaram a categoria adquirir informação sobre sexualidade humana.

Respostas dos dois sujeitos:

“A graduação poderia nos direcionar melhor de como orientar de maneira correta os jovens de hoje sobre sexualidade, doenças, assim como a gravidez precoce.” (S: 6)

"Espero que ofereça cursos e mais conhecimento sobre sexualidade, trazendo assim as doenças mais atuais em cada curso oferecido." (S: 17)

Enquanto educadoras, temos um papel fundamental na formação do enfermeiro, que é o de despertar o interesse desse futuro profissional para que não ignore as necessidades sexuais de seus clientes, para assim assistirem o indivíduo de maneira holística.

Encontramos algumas respostas que nos levaram a adotar a categoria conhecimento para si mesmo. Observamos que 4 sujeitos estavam preocupados em receberem conhecimento sobre a temática estudada para a sua própria vida.

Algumas respostas dos sujeitos:

"Espero que me prepare ainda mais para poder estar ajudando e informando outras pessoas e também para minha própria vida." (S: 3)

"Espero que me ofereça informações suficientes para poder usar na minha vida e principalmente saber passar para as pessoas mais informações sobre IST.” (S: 5)

"Espero que me disponibilize o máximo de conhecimento possível para que eu possa lidar da melhor maneira possível com o assunto tanto para meu benefício quanto para o das outras pessoas." $(\mathrm{S}: 10)$ 
Diante das respostas dos sujeitos acima, acreditamos ser natural e importante que os sujeitos ingressantes na universidade se interessem em adquirir mais conhecimento tanto para sua vida pessoal como para a profissional, visto que é impossível você falar/estudar/aprender sobre sexualidade e se dizer totalmente neutro diante deste tema, uma vez que a sexualidade é inerente ao ser humano e manifesta-se durante toda a vida (GIR; NOGUEIRA; PELÁ, 2000).

Alguns sujeitos se adequaram à categoria conhecimento para reforçar o que já sabia, e assim manifestaram através de suas respostas que já tinham conhecimento e que a graduação iria apenas complementar essas informações.

Respostas dos sujeitos:

"Acho que a graduação só vai reforçar o que eu já sabia.” (S:19)

"Só venha complementar o meu conhecimento." (S: 25)

Essas respostas vêm ao encontro das respostas obtidas na Tabela 11, em que 96,5\% dos alunos ingressantes disseram ter conhecimento suficiente sobre sexualidade e IST/aids antes de ingressar na faculdade. 
Quadro 4 - Distribuição das respostas dos 29 alunos do $1^{\circ}$ ano da graduação em enfermagem em relação à pergunta: Como você acha que seria a melhor maneira de aprender sobre o tema sexualidade humana, IST/aids durante a graduação em enfermagem? 2006

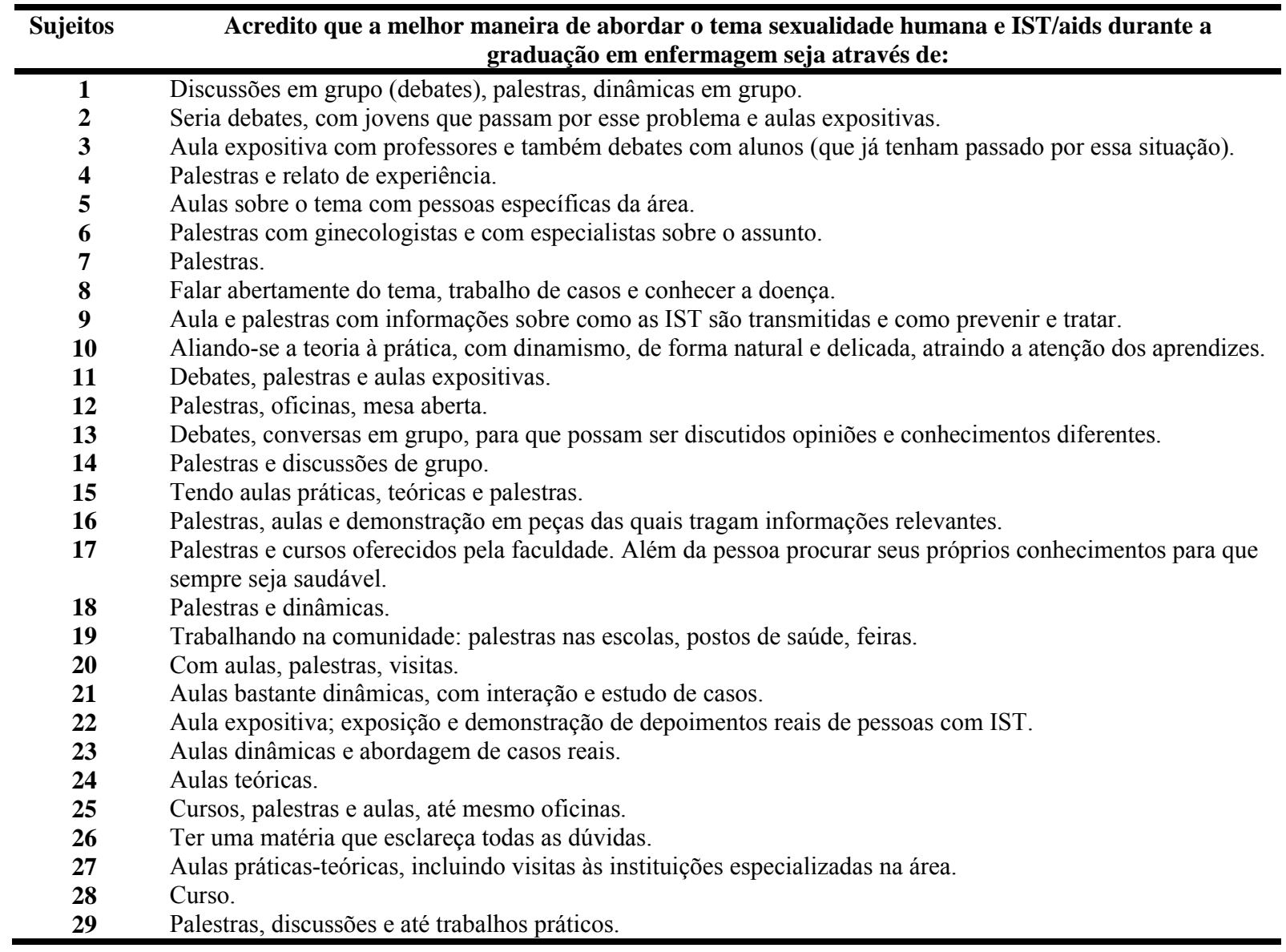

\section{Categorização sobre a melhor maneira de abordar o tema sexualidade humana e IST/aids na graduação em enfermagem.}

- $\quad$ Abordagem participativa (S: 4, 5, 6, 7, 9, 17, 20, 22, 24, 26, 28);

- Abordagem pouco participativa (S: 8, 10, 13, 19, 21, 23, 27).

- Abordagem Mista (abordagem participava e pouco participativa) (S: 1, 2, 3, 11, 12, 14, 15, 16, 18, 25, 29)

Para melhor análise e visualização dos dados, optamos por fazer as discussões dos

Quadros 4 e 5 após a categorização do Quadro 5. 
Quadro 5 - Categorização das respostas dos 30 alunos, do $4^{\circ}$ ano, em relação à pergunta: Como você acha que seria a melhor maneira de aprender sobre o tema sexualidade humana, IST/aids durante a graduação em enfermagem? 2006

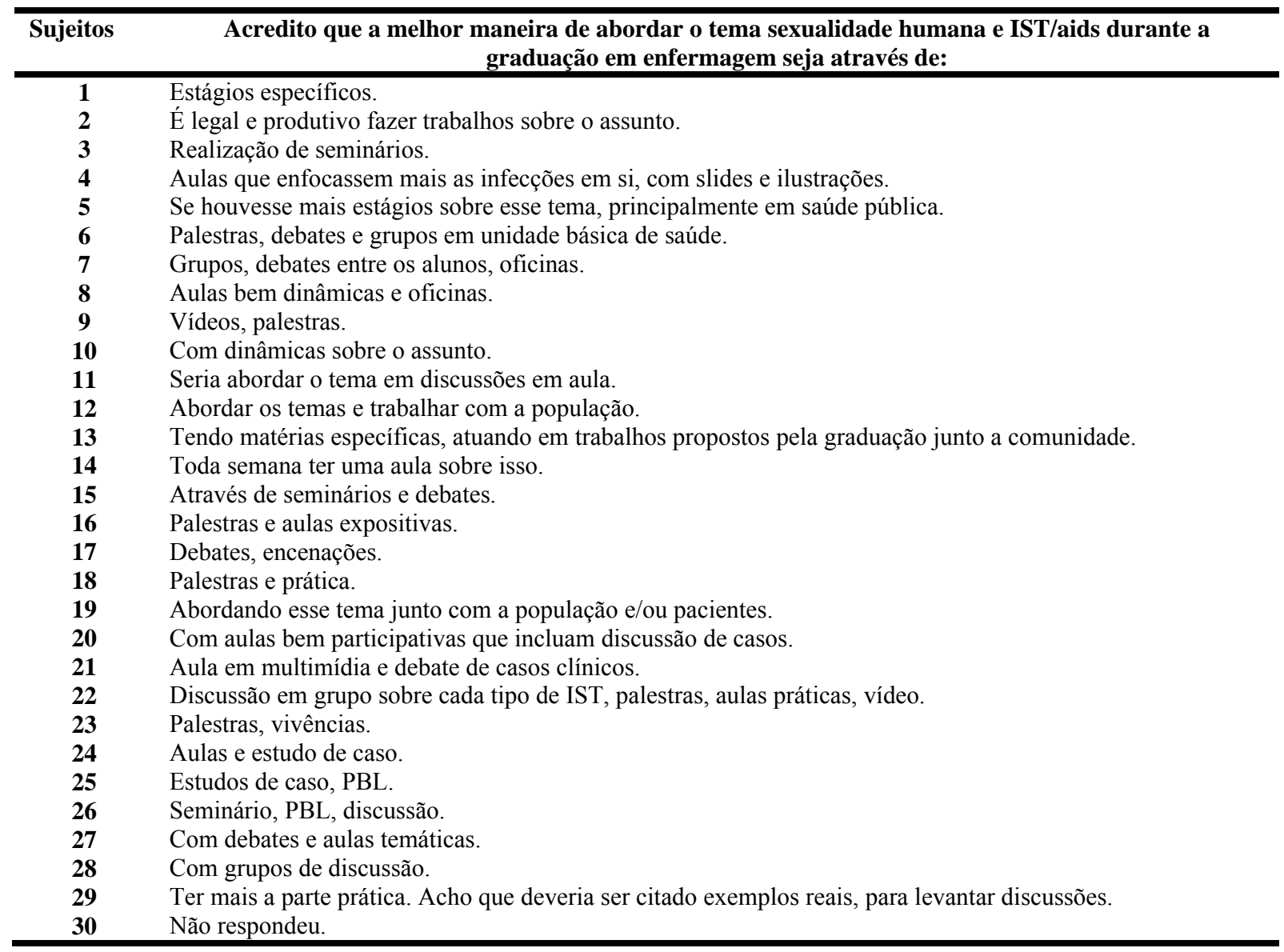

\section{Categorização sobre a melhor maneira de abordar o tema sexualidade humana e IST/aids na graduação em enfermagem.}

- Abordagem participativa (S: 1, 5, 7, 8, 10, 11, 12, 13, 15, 17, 19, 20, 24, 25, 26, 27, 28, 29);

- Abordagem pouco participativa (S: 4, 9, 14, 16);

- Abordagem Mista (abordagem participava e pouco participativa) (S: 2, 3, 6, 18, 21, 22, 23)

- $\quad$ Não respondeu (S: 30).

Ao analisar a opinião dos alunos do primeiro e quarto ano em relação a melhor maneira de aprender sobre o tema sexualidade e IST/aids, nos deparamos com diferenças marcantes entre as estratégias sugeridas pelos alunos que estão iniciando a graduação e os que estão finalizando-a.

Optamos por dividir as respostas em categorias: abordagem participativa, abordagem pouco participativa e abordagem mista. 
Entre os alunos do $1^{\circ}$ ano, as estratégias de ensino apontadas com maior freqüência foram as palestras e as aulas expositivas, sendo citadas algumas estratégias como dinâmicas, debates, discussões e oficinas.

Algumas respostas dos sujeitos do $1^{\circ}$ ano:

"Palestras com ginecologistas e com especialistas sobre o assunto." (S: 6)

"Aula e palestras com informações sobre como as IST são transmitidas e como prevenir e tratar." (S: 9)

“Aula expositiva; exposição e demonstração de depoimentos reais de pessoas com IST.” (S: 22)

Os alunos do último ano também fizeram referência a palestra e aulas expositivas, mas em menor freqüência. A grande maioria dos alunos optou por estágios, debates, discussões, dinâmicas, estudo de caso, entre outros, como pode ser observado nas respostas desses alunos:

"Com dinâmicas sobre o assunto.” (S: 10)

"Debates, encenações." (S: 17)

"Com aulas bem participativas que incluam discussão de casos." (S: 20)

“Com grupos de discussão.” (S: 28)

Diante das respostas acima podemos observar que os alunos do $4^{\circ}$ ano, grande parte optou pelas estratégias em que o aluno possa ter mais participação.

Notamos que, em relação à abordagem mista os alunos do $1^{\circ}$ ano citaram mais vezes este tipo de abordagem do que os alunos do último ano.

Respostas dos alunos:

$1^{\circ}$ ano

"Aula expositiva com professores e também debates com alunos (que já tenham passado por essa situação)." (S: 3)

"Cursos, palestras e aulas, até mesmo oficinas." (S: 25)

"Palestras, discussões e até trabalhos práticos." (S: 29) 


\section{$4^{0}$ ano}

"Palestras, debates e grupos em unidade básica de saúde." (S: 6)

"Palestras e prática." (S: 18)

“Discussão em grupo sobre cada tipo de IST, palestras, aulas práticas, vídeo.” (S: 22)

Pereira (2000) refere que as estratégias de ensino menos participativas (palestras e aulas expositivas), em regra, não permitem a participação sistemática do aluno, a exposição de seus valores e crenças para proporcionar a reflexão e tomada de consciência sobre os mesmos.

Dessa maneira, a educação se torna um ato de depositar, em que os educandos são depositários e o educador o depositante. Eis aí a concepção "bancária", a qual anula o poder criador dos educandos ou minimiza, estimulando sua ingenuidade e não sua criticidade (FREIRE, 2000, pg. 66).

Frente aos dados, achamos interessante o quanto a formação tradicional ainda direciona os interesses dos alunos ingressantes na vida universitária, na qual o educador é quem educa, e os educandos os que são educados e ainda o educador é o sujeito do processo, e os educandos, meros objetos (FREIRE, 2000).

Compreendemos a visão dos alunos iniciantes, uma vez que, se observarmos o nosso sistema educacional, vemos que a educação "bancária" está presente em todo o processo educativo e nada mais natural que estes alunos ingressantes na faculdade sugiram como estratégias de ensino aquilo que lhes foi ensinado.

Por outro lado, os alunos que estão no $4^{\circ}$ ano já tiveram a oportunidade de ter contato com algumas metodologias crítico-social durante a sua graduação, e diante disso puderam avaliar as diferenças entre as formas de se educar, por isso citaram algumas estratégias mais participativas (dinâmicas, debates, discussões, entre outros) também chamadas de problematizadoras e libertadoras por Paulo Freire. 
Pereira (2000) acredita que a estratégia participativa seja a mais adequada para grande parte dos temas relacionados à sexualidade, desde que haja pacto de confiança entre professor/aluno.

Freire (2000) nos ensina que, na prática problematizadora, os educandos têm capacidade de desenvolver o seu poder de captação e compreensão do mundo que lhes parece, pois há o diálogo entre educando e educador.

Dessa forma, o autor acima acredita que a tendência, então, do educador-educando como dos educandos-educadores é estabelecerem uma forma autêntica de pensar e atuar.

Diante dos dados expostos, acreditamos na importância que a graduação, assim como seus professores, têm em relação à mudança da forma de educar.

Temas como sexualidade, que envolve crenças, hábitos, costumes e também por envolverem intimidade e privacidade, necessitam de uma abordagem diferenciada, de modo mais acessível, aberta, dialogal e próxima do cotidiano, ou seja, de forma não tradicional e sim mais participativa.

No entanto, muitas vezes, para transmitir conhecimento de natureza biológica, a aula expositiva é de imensa utilidade para o desenvolvimento desses temas.

Dessa maneira, sabemos da importância da aula expositiva, mas não podemos deixar de lado a metodologia problematizadora, que contribui para a formação de um enfermeiro autêntico, investigador, crítico, reflexivo e aberto ao diálogo. 
Quadro 6 - Distribuição das respostas dos 30 alunos do $4^{\circ}$ ano da graduação em enfermagem em relação à pergunta: Você acredita que o que a graduação em enfermagem the oferece de informações sobre sexualidade humana e as IST/aids é o suficiente para que você possa desenvolver o seu trabalho como enfermeiro quando sair da faculdade? Por quê? 2006

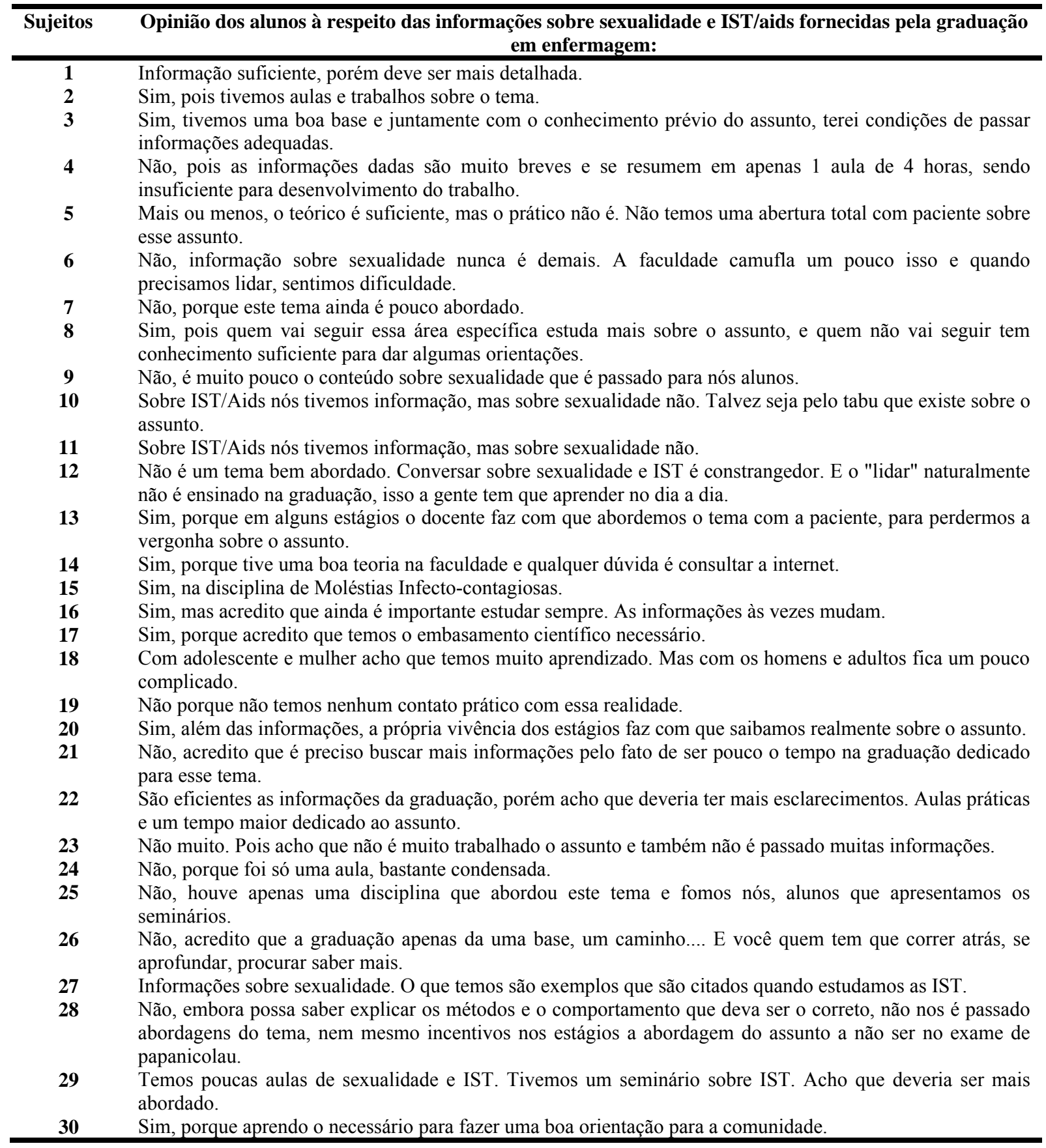

\section{Categorização sobre a opinião dos alunos do $4^{\circ}$ ano a respeito do seu preparo enquanto enfermeiro para trabalhar com a temática sexualidade e IST/aids}

- Tivemos informações suficientes (S: 1, 2, 3, 8, 10, 11, 13, 14, 15, 16, 17, 18, 20, 22, 30);

- Não tivemos informações suficientes (S: 4, 6, 7, 9, 12, 19, 21, 23, 24, 25, 26, 27, 28, 29);

- Dificuldade em abordar o tema com o paciente (S: 4, 5, 6, 12, 18, 28);

- Informação sobre IST/aids e não sobre sexualidade (S: 10, 11). 
Ao perguntarmos se as informações que os alunos receberam foram suficientes para lidarem com seus futuros pacientes, houve uma divisão, quase que total, entre os sujeitos pesquisados.

Em relação a categoria tivemos informações suficientes, encontramos algumas respostas:

"Sim, pois tivemos aulas e trabalhos sobre o tema." (S: 2$)$

"Sim, tivemos uma boa base e juntamente com o conhecimento prévio do assunto, terei condições de passar informações adequadas." (S: 3)

"Sim, porque acredito que temos o embasamento científico necessário." (S: 17)

Mas, entre os sujeitos que disseram ter tido conhecimento suficiente, alguns fazem sugestões para melhorar o ensino.

Resposta dos alunos:

"Informação suficiente, porém deve ser mais detalhada." (S: 18)

"Com adolescente e mulher acho que temos muito aprendizado. Mas com os homens e adultos fica um pouco complicado." (S:18)

"São eficientes as informações da graduação, porém acho que deveria ter mais esclarecimentos. Aulas práticas e um tempo maior dedicado ao assunto.” (S: 22)

Em contrapartida, encontramos 14 sujeitos na categoria não tivemos informações suficientes.

Algumas respostas dos acadêmicos:

"Não, pois as informações dadas são muito breves e se resumem em apenas 1 aula de 4 horas, sendo insuficiente para desenvolvimento do trabalho." (S: 4)

"Não, porque este tema ainda é pouco abordado." (S: 7)

"Não, é muito pouco o conteúdo sobre sexualidade que é passado para nós alunos." (S: 9)

"Não, porque foi só uma aula, bastante condensada." (S: 24) 
Gir, Nogueira e Pelá (2000), investigando a questão da sexualidade humana na formação do enfermeiro, encontraram que, entre os sujeitos entrevistados, 56,8\% referiram ter tido um ensino insuficiente, 20,45\% classificaram como regular, 6,8\% como péssimo, 4,54\% como bom e 2,27\% não responderam.

Enquanto que no nosso estudo encontramos que 15 sujeitos $(50 \%)$ referiram ter tido informações suficientes sobre sexualidade e IST/aids.

Pereira (2000) em seu estudo questiona os professores de enfermagem a respeito de seu preparo para lidar/abordar assuntos de sexualidade, e verifica que 95,5\% obtiveram informações sobre sexualidade em cursos extras, 40,9\% em situações vivenciadas, $31,8 \%$ em sua educação familiar e apenas $27,3 \%$ vieram do curso de graduação em enfermagem.

Apenas dois alunos fizeram parte da categoria informação sobre IST/aids e não sobre sexualidade, o que pode ser visto nas falas abaixo:

"Sobre IST/Aids nós tivemos informação, mas sobre sexualidade não. Talvez seja pelo tabu que existe sobre o assunto." (S: 10)

"Sobre IST/Aids nós tivemos informação, mas sobre sexualidade não." (S: 11)

Pelá et al. (1995), no estudo com enfermeiros, verificou que 97,99\% desses profissionais declararam ser necessário adquirir conhecimento sobre sexualidade humana durante a formação profissional.

Ramin e Soler (2002), também trabalhando com enfermeiros, relatam que os professores não têm consciência de que estão sendo superficiais e pouco reflexivos na abordagem da sexualidade.

Seis sujeitos fizeram parte da categoria dificuldade em abordar o tema com o paciente. 
Vejamos algumas respostas:

"Mais ou menos, o teórico é suficiente, mas o prático não é. Não temos uma abertura total com paciente sobre esse assunto." (S: 5)

"Não, informação sobre sexualidade nunca é demais. A faculdade camufla um pouco isso e quando precisamos lidar, sentimos dificuldade." (S: 6)

"Não é um tema bem abordado. Conversar sobre sexualidade e IST é constrangedor. E o "lidar" naturalmente não é ensinado na graduação, isso a gente tem que aprender no dia a dia." (S: 12)

"Não, embora possa saber explicar os métodos e o comportamento que deva ser o correto, não nos é passado abordagens do tema, nem mesmo incentivos nos estágios a abordagem do assunto a não ser no exame de papanicolau." (S: 28)

Com relação à dificuldade em abordar a sexualidade com o paciente, Pelá et al. (1995) averiguaram que 79,06\% dos enfermeiros entrevistados disseram ter desvantagens em não ter recebido informações suficientes sobre sexualidade. Dentre essas desvantagens, 40 profissionais referiram a "dificuldade para conversar e/ou orientar cliente e família sobre o assunto, seguido da falta de conhecimento específico", o qual foi citado por 39 sujeitos.

Gir, Nogueira e Pelá (2000) relatam que o enfermeiro encontra dificuldade em analisar o comportamento do indivíduo, responder a questionamentos, orientar sobre determinada medicação que possa interferir na sexualidade do paciente, entre outros. Dessa maneira, ao tentar abordar essa temática como seus clientes, o enfermeiro deixa transparecer dúvida, vergonha, insegurança e quando não, fuga. 
Quadro 7 - Distribuição das respostas dos 30 alunos, do $4^{\circ}$ ano, em relação à pergunta: Além do conhecimento sobre sexualidade humana e IST/aids que a graduação em enfermagem já ofereceu para você, o que mais você acredita que a graduação em enfermagem poderia fornecer para que você pudesse atuar com mais "segurança" em relação à sexualidade humana e IST/aids diante dos seus futuros pacientes? Apresente sugestões. 2006

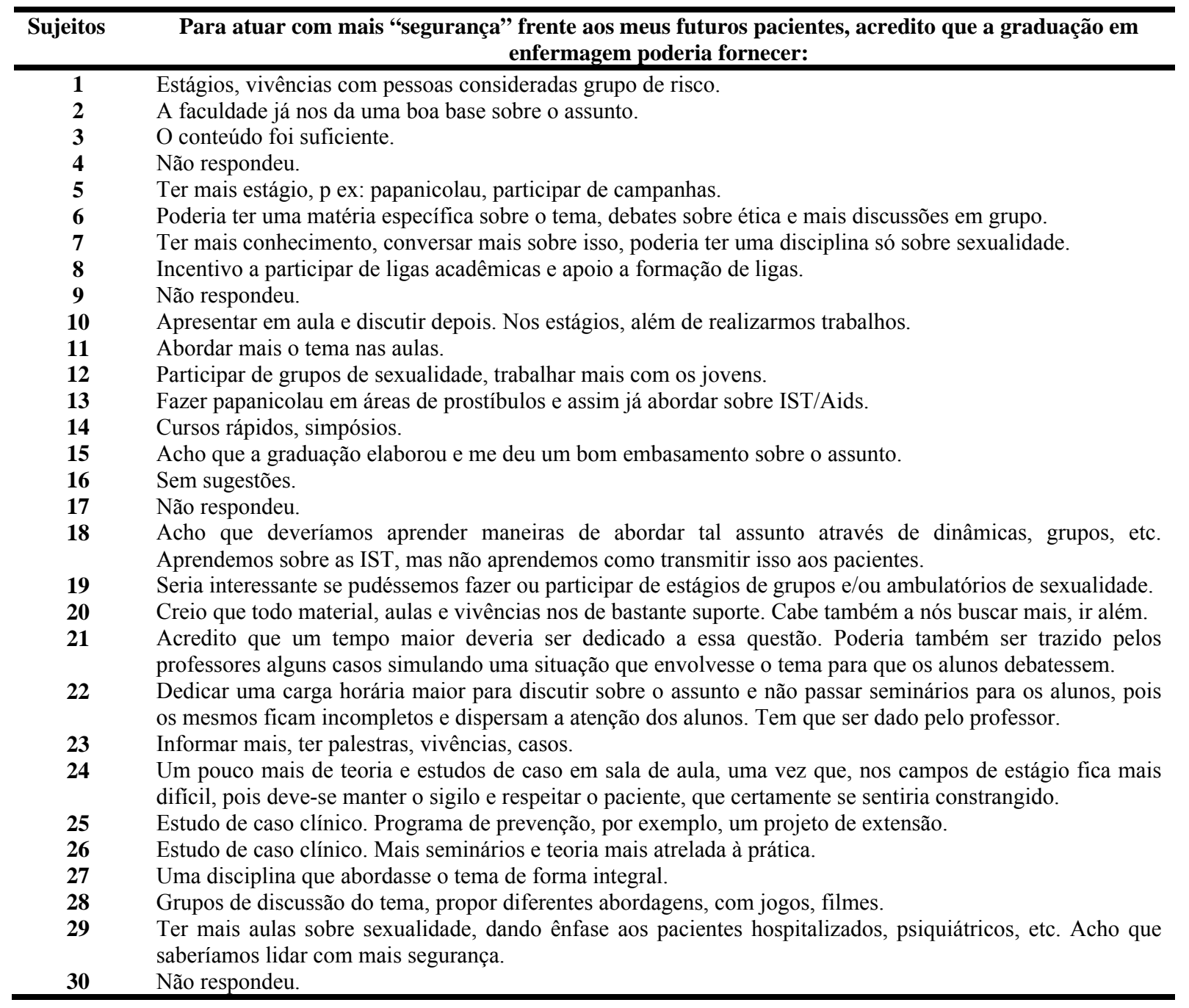

\section{Categorização sobre o que a graduação em enfermagem pode fornecer para dar maior segurança para o aluno lidar com questões referentes à sexualidade e IST/aids}

- Utilizar uma metodologia participativa (S: 1, 5, 6, 7, 8, 10, 12, 13, 18, 19, 21, 22, 23, 25, 26, 28);

- Utilizar uma metodologia menos participativa (S: 10, 11, 14, 23, 24, 25, 26, 29);

- Não respondeu (S: 4, 9, 16, 17, 30);

- A graduação já forneceu informação (S: 2, 3, 15, 20);

- Necessidade de ter uma disciplina sobre sexualidade (S: 6, 7, 27).

Dentre o conjunto de respostas atribuídas ao Quadro 7, verificamos que 16 sujeitos se encontram na categoria utilizar uma metodologia participativa, sendo que manifestaram 
grande interesse de ter a temática sexualidade e IST/aids abordada durante estágios, projeto de extensão e ligas acadêmicas, como podemos observar nas respostas abaixo:

“Ter mais estágio, p ex: papanicolau, participar de campanhas." (S: 5)

"Incentivo a participar de ligas acadêmicas e apoio a formação de ligas." (S: 8)

"Fazer papanicolau em áreas de prostíbulos e assim já abordar sobre IST/Aids." (S: 13)

"Seria interessante se pudéssemos fazer ou participar de estágios de grupos e/ou ambulatórios de sexualidade." (S: 19)

"Estudo de caso clínico. Programa de prevenção, por exemplo, um projeto de extensão." (S: 25)

Dentro da categoria citada acima, tivemos ainda alguns alunos que explicitaram a pretensão de terem, durante a parte teórica, a abordagem de uma metodologia de ensino que fosse mais participativa.

Algumas respostas dos sujeitos:

"Acredito que um tempo maior deveria ser dedicado a essa questão. Poderia também ser trazido pelos professores alguns casos simulando uma situação que envolvesse o tema para que os alunos debatessem". (S: 21)

"Dedicar uma carga horária maior para discutir sobre o assunto e não passar seminários para os alunos, pois os mesmos ficam incompletos e dispersam a atenção dos alunos. Tem que ser dado pelo professor". (S: 22)

“Grupos de discussão do tema, propor diferentes abordagens, com jogos, filmes". (S: 28)

Podemos verificar que há uma coerência entre as respostas fornecidas pelos mesmos alunos no Quadro 6, quando perguntamos sobre qual seria a melhor maneira de apreender sobre sexualidade e IST/aids.

Garcia (1993) já referia a necessidade de se ter uma disciplina sobre sexualidade e enfatizava que, enquanto os próprios sentimentos, atitudes, crenças, valores, conceitos ou comportamentos a respeito da sexualidade não estiverem claros, o enfermeiro não se sentirá 
seguro para abordar o assunto com a clientela, utilizando da sensibilidade, objetividade e empatia requerida.

Acreditamos que a metodologia participativa seja interessante para trabalhar o aspecto afetivo-emocional do aluno de enfermagem, permitindo que ele tenha consciência de suas dificuldades e potencialidades em relação ao trabalho com a temática sexualidade e IST/aids, junto aos seus pacientes.

Encontramos em uma das respostas dos alunos que eles aprendem sobre IST/aids, mas não aprendem como transmiti-la ao paciente.

"Acho que deveríamos aprender maneiras de abordar tal assunto através de dinâmicas, grupos, etc. Aprendemos sobre as IST, mas não aprendemos como transmitir isso aos pacientes." (S: 18)

A resposta da aluna acima vem ao encontro dos achados na pesquisa de Gir, Nogueira e Pelá (2000), em que entrevistando graduandos da enfermagem encontrou que 42,5\% têm convicção da necessidade de obterem conhecimento sobre sexualidade para utilizarem na prática profissional da saúde, $17,5 \%$ referem que a sexualidade não pode ser dissociada, pois é parte integrante do ser humano, e 15\% revelaram a preocupação em exercer o papel de educador com segurança.

Em relação à categoria utilizar uma metodologia menos participativa, encontramos 8 sujeitos.

Respostas dos sujeitos:

"Abordar mais o tema nas aulas." (S: 11)

"Cursos rápidos, simpósios.” (S: 14)

"Um pouco mais de teoria e estudos de caso em sala de aula, uma vez que, nos campos de estágio fica mais difícil, pois deve-se manter o sigilo e respeitar o paciente, que certamente se sentiria constrangido." (S: 24) 
Acreditamos que algumas estratégias de ensino sendo, como aula teórica expositiva, cursos rápidos, simpósios e palestras, proporcionam uma participação menos efetiva do aluno em relação ao conteúdo estudado/apresentado.

Freire (1996) relata que, nas condições de verdadeira aprendizagem, os educandos vão se transformando em reais sujeitos da construção e da reconstrução do saber ensinado, ao lado do educador, igualmente sujeito do processo. Só assim podemos falar realmente de saber ensinado, em que o objeto ensinado é aprendido na sua razão de ser e, portanto, aprendido pelos educandos.

Encontramos 4 sujeitos na categoria a graduação já forneceu informação, sendo que se sentem preparados para lidarem com seus pacientes sobre o tema sexualidade e IST/aids, como podemos ver nas respostas abaixo:

"A faculdade já nos da uma boa base sobre o assunto." (S: 2)

"O conteúdo foi suficiente." (S: 3 )

“Acho que a graduação elaborou e me deu um bom embasamento sobre o assunto." (S: 15)

"Creio que todo material, aulas e vivências nos de bastante suporte. Cabe também a nós buscar mais, ir além." (S: 20)

Do total pesquisado, 3 sujeitos abordavam na categoria necessidade de ter uma disciplina sobre sexualidade a importância de se ter uma disciplina que abordasse exclusivamente essa temática.

Resposta dos alunos:

"Poderia ter uma matéria específica sobre o tema, debates sobre ética e mais discussões em grupo." (S: 6)

"Ter mais conhecimento, conversar mais sobre isso, poderia ter uma disciplina só sobre sexualidade." (S: 7)

"Uma disciplina que abordasse o tema de forma integral." (S: 27) 
Há mais de duas décadas, Egry (1985) já afirmava que a não inclusão explícita da temática sexualidade humana nos currículos mínimos de enfermagem constitui uma omissão histórica, tradicionalista e moralista.

Garcia (1993) considera que uma das razões para a aparente inabilidade do enfermeiro para assumir a responsabilidade de abordar aspectos da sexualidade humana com a clientela seja a lacuna existente no currículo do curso de enfermagem, que não inclui em sua programação um estudo aprofundado do assunto.

Gir, Nogueira e Pelá (2000) acreditam que, se o aluno de enfermagem adquirisse mais conhecimento sobre a temática durante a graduação, ele seria capaz de tratar o homem como um ser holístico, com seus múltiplos processos interdependentes, sendo a sexualidade um dos processos intrínsecos ao seu ser.

Nesta pergunta, tivemos 5 sujeitos que não responderam à questão.

Tabela 12 - Distribuição das respostas dos alunos do $4^{\circ}$ ano, em relação à pergunta: Em qual (ais) disciplina (as) você teve contato com o tema sexualidade e IST/aids? 2006

\begin{tabular}{lc}
\hline \multicolumn{1}{c}{ DISCIPLINAS CITADAS PELOS ALUNOS* } & $\begin{array}{c}\mathbf{4}^{\circ} \text { ANO GRADUAÇÃO } \\
\mathbf{N}=\mathbf{3 0}\end{array}$ \\
\hline \multicolumn{1}{c}{ RESPOSTAS } & $\mathbf{N}^{\circ}$ de vezes em que foi citada \\
\hline Moléstias infecto contagiosas & 25 \\
Ginecologia & 17 \\
Obstetrícia & 07 \\
Saúde pública & 06 \\
Relacionamento enfermeiro paciente & 04 \\
Psiquiatria & 02 \\
Psicologia & 02 \\
Dermatologia & 01 \\
Administração em enfermagem & 01 \\
\end{tabular}

* Houve mais de uma resposta para alguns sujeitos

Diante das respostas apresentadas na Tabela 12, verificamos que as disciplinas que fazem parte do elenco do curso de graduação em enfermagem e que ofereceram alguma noção ou embasamento sobre sexualidade foram: moléstias infecto contagiosas 25 vezes; 
ginecologia: 17; obstetrícia: 07; saúde pública: 06; relacionamento enfermeiro-paciente: 04; psiquiatria e psicologia: 02; dermatologia e administração em enfermagem: 01.

Gir, Nogueira e Pelá (2000) encontraram em seu estudo com graduandos em enfermagem que a matéria que mais ofereceu alguma noção ou embasamento sobre sexualidade foi a disciplina de ginecologia, seguida pela obstetrícia, psicologia, saúde pública, psiquiatria, enfermagem médica, anatomia, fisiologia e saúde do escolar.

Dessa maneira, podemos notar que a disciplina de moléstias infecto contagiosa não foi citada no estudo de Gir, Nogueira e Pelá (2000), visto que as autoras perguntaram apenas sobre o tema sexualidade, não incluindo às IST/aids. Isto ocorre porque essa disciplina acaba sendo responsável por apresentar ao aluno as formas de transmissão, tratamento e prevenção das IST/aids, não tendo como foco principal a temática sexualidade.

É interessante, aqui, observarmos o aparecimento da disciplina de saúde pública. Acreditávamos que essa disciplina fosse aparecer mais vezes, pois algumas abordagens na saúde pública envolvem temas relacionados à sexualidade, especialmente nos dias atuais, em que temos cada vez mais pessoas procurando o serviço de saúde em busca de informações e tratamento para às IST/aids.

Diante disso, aproveitamos a oportunidade para indagar essa questão e sugerir que os conteúdos curriculares das disciplinas sejam investigados, para que possam realmente acompanhar as mudanças que ocorrem na nossa sociedade.

Investigando o ensino da sexualidade humana em 1984 e 1985, em uma escola de enfermagem da capital paulista, Egry (1985) apresentou a ausência da temática na grade curricular e a falta de preocupação em ministrar este ensino.

Já em 1997, realizando o estudo sobre sexualidade humana nos cursos de enfermagem no Estado de São Paulo, Pereira (2000) verificou que em nenhuma das instituições pesquisadas foi registrada a disciplina denominada sexualidade humana, e ressalta que este 
assunto é diluído em várias disciplinas, dependendo talvez da disponibilidade ou da competência específica do professor para a abordagem do tema.

O mesmo autor enfatiza que a matéria sobre sexualidade humana deva ser multidisciplinar, mas nos lembra que a abordagem deve ocorrer de forma integrada para garantir a adequada formação do profissional.

Tabela 13 - Distribuição das respostas de 30 indivíduos, do $4^{\circ}$ ano em relação à pergunta: Você já passou por alguma situação durante a graduação em enfermagem (p. ex: estágios) em que você teve que ter conhecimento sobre o tema sexualidade/IST/aids? 2006

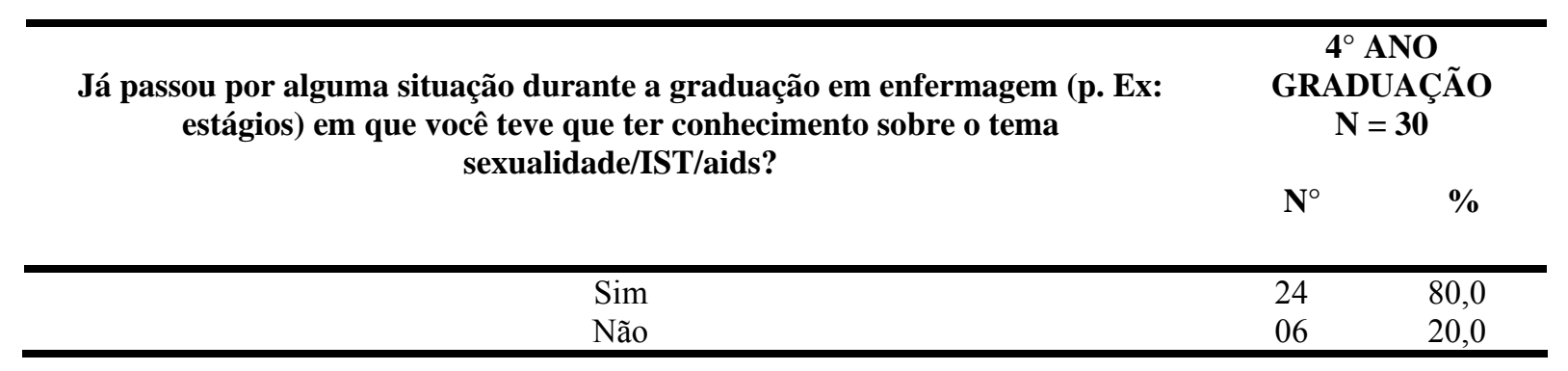

Concluímos que $80 \%$ dos alunos do último ano haviam vivenciado alguma situação acadêmica que exigiu seu conhecimento sobre o assunto.

Em seu trabalho com estudantes da graduação em enfermagem Gir, Nogueira e Pelá (2000) encontraram que $72,5 \%$ dos entrevistados já haviam vivenciado alguma situação acadêmica onde tiveram que abordar o tema sexualidade e/ou IST/aids.

Pesquisando o profissional enfermeiro, Pelá et al. (1995) verificaram que 61,07\% dos sujeitos já vivenciaram situações que exigiram conhecimento sobre sexualidade humana, enquanto $34,89 \%$ não passaram por esta situação.

Esses dados nos mostram o quanto é freqüente o aluno e/ou profissional de enfermagem vivenciar situações sobre a temática em apreço. 
Quadro 8 - Distribuição das respostas dos alunos do $4^{\circ}$ ano em relação à questão: Descreva rapidamente uma situação vivida por você onde você teve que ter conhecimento sobre o tema sexualidade/IST/aids. 2006

Durante a graduação em enfermagem tive que ter conhecimento sobre sexualidade e/ou IST/aids diante da seguinte situação:

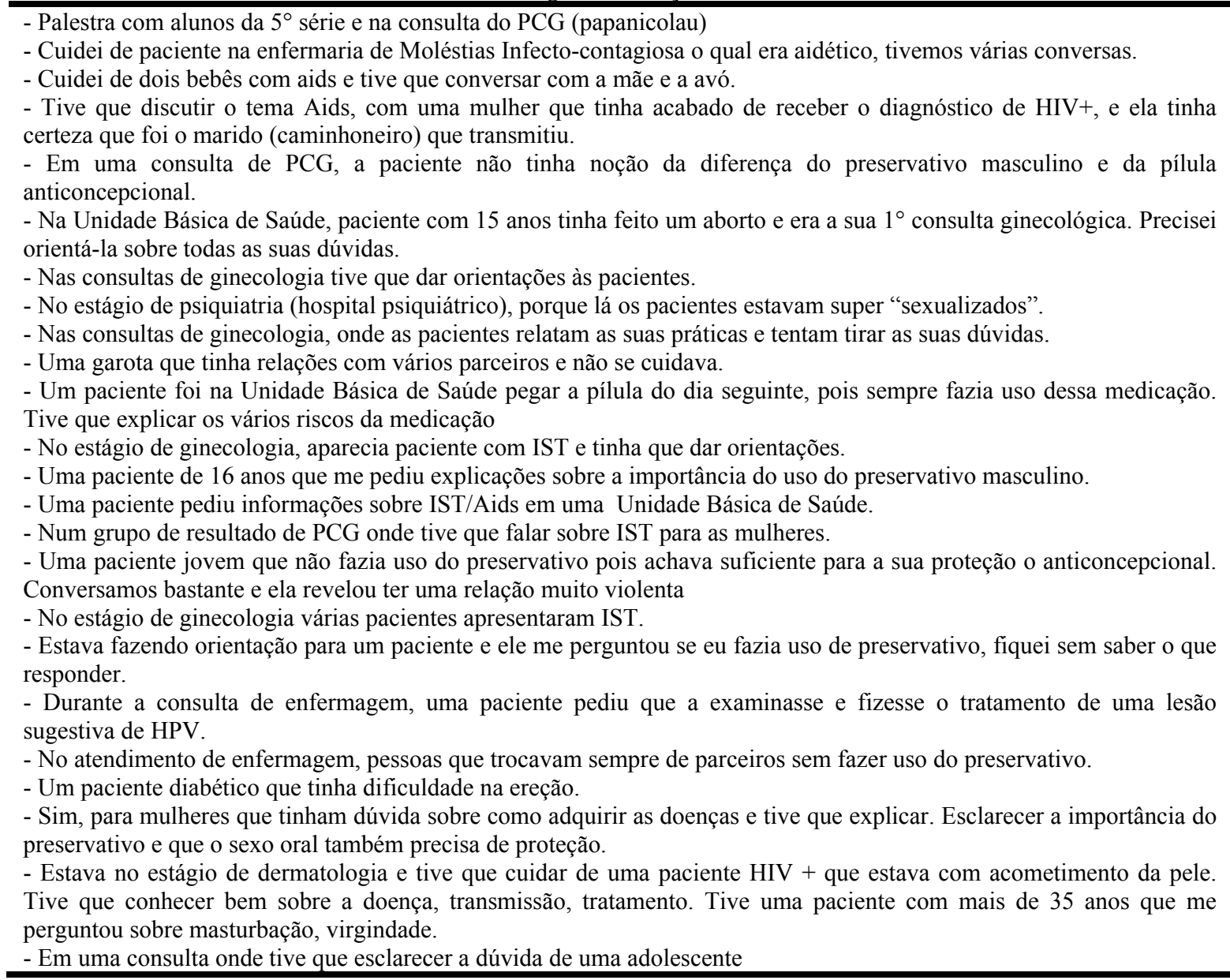

\section{Categorização sobre alguma situação vivenciada pelo aluno do $4^{\circ}$ ano em relação à temática sexualidade e IST/aids.}

Algumas temáticas vivenciadas pelos graduandos na orientação sobre:

- IST/aids (S: 2, 3, 4, 10, 12, 14, 15, 17, 19, 22, 23)

- Métodos contraceptivos (S: 5, 11, 13, 16, 18, 20, 22)

- Orientação sexual/ relacionamento sexual (S: 1, 7, 8, 9, 10, 24)

- $\quad$ Aborto (S: 6)

- Impotência sexual (S: 21)

- Masturbação (S: 23)

- Relação sexual oral (S: 22)

- Seis sujeitos não responderam

Ao serem questionados a explicitarem uma destas situações, 24 sujeitos $(80 \%)$ dos que responderam terem tido uma situação acadêmica onde tiveram que abordar a temática, todos relataram uma ou mais situações vivenciadas, quer através de palestras, consultas de 
enfermagem e estágios, o que totalizou 28 vivências. As principais abordagens foram:

IST/aids, citada 11 vezes; métodos contraceptivos: 07; orientação sexual/ relacionamento sexual: 06; aborto, impotência sexual, masturbação e relação sexual oral: 01.

Gir, Nogueira e Pelá (2000) verificaram que 16 alunos haviam citado uma ou mais situações vivenciadas, sendo que, dos assuntos mais abordados pelos graduandos, as autoras encontraram com maior freqüência: sexo e gravidez, orgasmo, sexo e puerpério, métodos contraceptivos, relacionamento sexual entre outros.

Pelá et. al (1995) relataram, entre as situações vivenciadas pelos enfermeiros, o “esclarecimento e orientação de paciente envolvendo questões sexuais”, a qual foi citada 39 vezes. Com menor freqüência, as autoras encontraram: "paciente psiquiátrico com distúrbio sexual", "paciente referindo impotência”, "homossexualismo", entre outros.

Quadro 9 - Distribuição das respostas dos alunos do $4^{\circ}$ ano em relação à questão: Qual é ou foi o sentimento que você teve ao ter que abordar o tema sexualidade/IST/aids com um paciente? 2006

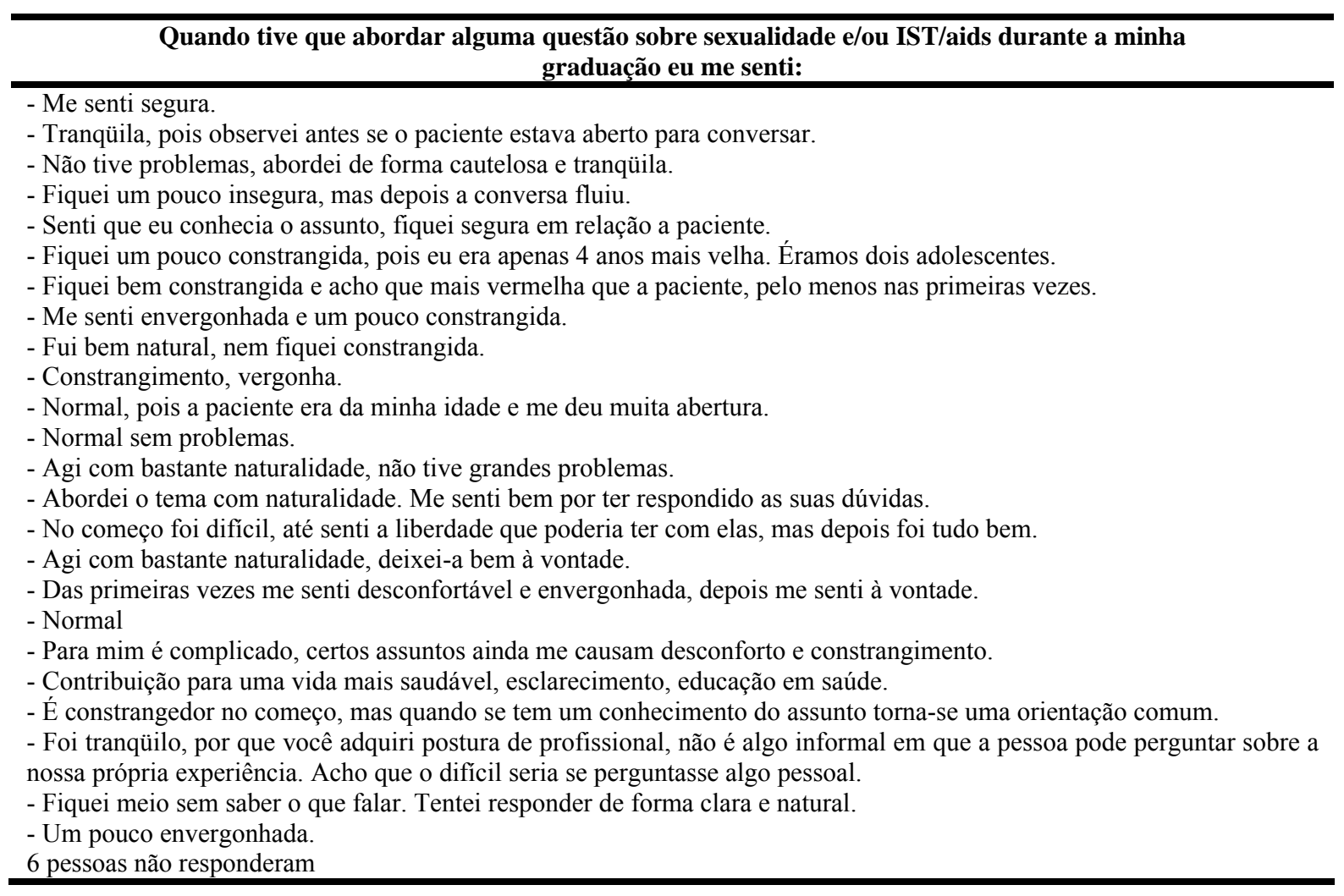




\section{Categorização sobre o sentimento que o aluno do $4^{\circ}$ ano teve quando abordou a temática sexualidade e IST/aids.}

Em relação ao sentimento que teve em abordar a sexualidade com o paciente, todos os sujeitos que referiram ter vivenciado uma situação acadêmica relataram qual foi o seu sentimento. Classificamos em três grupos, segundo Gir, Nogueira e Pelá (2000).

Alguns sentimentos vivenciados pelos graduandos na orientação prestada:

- Comportamento positivo e desejado (S: 1, 2, 3, 5, 9, 11, 12, 13, 14, 15, 16, 17, 18, 22, 23);

- Reações negativas e indesejadas (S: 4, 6, 7, 8, 10, 15, 17, 19, 21, 23, 24);

- Resposta neutra (S: 20);

Seis pessoas não responderam. Das que responderam, encontramos 15 sujeitos que relataram terem tidos comportamentos positivos, seguido de 11 alunos com reações negativas e apenas um referiu uma resposta neutra, enquanto Gir, Nogueira e Pelá (2000) encontraram 28 reações negativas, seguida de 18 comportamentos positivos e 8 respostas neutras.

Concordamos com as autoras acima quando afirmam que as respostas negativas remetem à questão do despreparo não só cognitivo, como de treino específico para lidar com a situação.

Dessa maneira, podemos verificar a importância da qualidade da formação dos alunos de enfermagem, não esquecendo que o preparo desses futuros profissionais está diretamente interligado ao preparo dos seus professores.

Egry (1985, p. 124-5), verificando o ensino da sexualidade humana em uma escola de enfermagem, evidenciou a ansiedade dos docentes para melhorarem o ensino da enfermagem em relação à temática. Os professores apresentaram duas alternativas para proporcionar aos alunos de enfermagem um ensino mais crítico e consciente: "tomar maior consciência sobre a sua própria sexualidade e assim iniciar um diálogo mais franco e honesto; a segunda se baseia na aquisição de conhecimento profundos e específicos, através de leitura, discussão e reflexão, com isso podendo procurar, em conjunto com os alunos, as soluções para os problemas que ocorrem no dia-a-dia de nossas relações profissionais e pessoais.” 
Os professores, em especial da graduação, são muito importantes no processo de educar os futuros profissionais que são multiplicadores no exercício da profissão (RAMIN E SOLER, 2002).

Vitiello (1994) nos ensina que educar alguém consiste em fornecer subsídios e modelos para o crescimento pessoal e a ascensão de ideais e de comportamentos próprios. É um processo complexo, que requer tempo e influência de pessoas significativas.

\section{- Subsídios para trabalhar as necessidades}

Tabela 14 - Distribuição numérica e percentual das respostas dos alunos do $1^{\circ}$ e $4^{\circ}$ ano da graduação em enfermagem, em relação à pergunta: Você gostaria de participar de uma oficina de trabalho, onde estaremos desenvolvendo atividades educativas sobre sexualidade humana e IST/aids? 2006

\begin{tabular}{|c|c|c|c|c|c|c|}
\hline \multirow{2}{*}{$\begin{array}{c}\text { VOCÊ GOSTARIA DE PARTICIPAR } \\
\text { DE UMA OFICINA DE TRABALHO? } \\
\text { RESPOTAS }\end{array}$} & \multicolumn{2}{|c|}{$\begin{array}{c}1^{\circ} \text { ANO } \\
\text { GRADUAÇÃO } \\
\text { N = } 29\end{array}$} & \multicolumn{2}{|c|}{$\begin{array}{c}4^{\circ} \text { ANO } \\
\text { GRADUAÇÃO } \\
\text { N = } 30\end{array}$} & \multicolumn{2}{|c|}{$\begin{array}{l}\text { TOTAL } \\
\mathbf{N}=59\end{array}$} \\
\hline & $\mathbf{N}^{\circ}$ & $\%$ & $\mathbf{N}^{\circ}$ & $\%$ & $\mathbf{N}^{\circ}$ & $\%$ \\
\hline Sim & 23 & 79,4 & 24 & 80,0 & 47 & 79,7 \\
\hline Não & 06 & 20,6 & 06 & 20,0 & 12 & 20,3 \\
\hline
\end{tabular}

Quase $80,0 \%$ dos entrevistados manifestaram o interesse em participar da oficina de trabalho relacionada à sexualidade e IST/aids. 
Quadro 10 - Distribuição das impressões dos alunos de $1^{\circ}$ e $4^{\circ}$ ano, em relação ao espaço oferecido aos alunos para expressar o que quisessem. 2006

\section{IMPRESSÕES DEIXADAS PELOS ALUNOS}

$\mathbf{1}^{\circ}$ ano
- Achei o trabalho super interessante.
- Parabéns pelo trabalho.
- Um trabalho muito interessante a ser desenvolvido.
- Muito interessante a abordagem desse tema.
$\mathbf{4}^{\circ}$ ano
- Embora a graduação aborde o tema, há situações que surgem
insegurança e dúvidas.
- Muito bom este trabalho, espero que possa abrir mais espaços para
melhor discussão sobre sexualidade.
- Acredito ser um trabalho bastante interessante, pois no nosso próprio
meio discente há casos relacionados à sexualidade e IST/aids.
- É muito importante que trabalhos como esse sejam feitos para
promover o aumento dos debates do tema, e que dêem frutos práticos e
objetivos a respeito de como praticar o tema em nosso campo de
trabalho.

Podemos verificar, através das respostas acima, o quanto os alunos de graduação acreditam ser interessante o estudo da sexualidade humana e IST/aids na formação do enfermeiro. 


\section{$3^{\circ}$ Etapa}

\section{- Ações/intervenções educativas do processo realizado na oficina pedagógica}

Após identificados alguns dos problemas e dúvidas sobre a temática junto aos alunos do $1^{\circ}$ e $4^{\circ}$ ano da Graduação em Enfermagem, passamos a ter uma visão mais real da problematização em foco. Seguem o planejamento e o relato do que realizamos durante a oficina bem como a avaliação da mesma.

Ressaltamos que no decorrer do desenvolvimento da oficina pedagógica foi possível levantar alguns problemas que até então com a análise dos questionários eles não haviam aparecido. Verificamos dessa forma o quanto esta intervenção educativa foi importante para a complementação dos nossos dados.

\section{Título: Educação para sexualidade e IST/aids}

I) Identificação: alunos do $1^{\circ}$ e $4^{\circ}$ ano da graduação em enfermagem

II) Objetivo: realizar, junto aos universitários, uma oficina pedagógica onde serão trabalhadas questões sobre sexualidade, práticas sexuais de risco e as IST/aids, sensibilizando-os para hábitos e atitudes seguros relacionados ao sexo ativo, além de prepará-los para serem agentes multiplicadores desse saber.

\section{III) Temas (programa):}

1) Sexualidade ao longo da vida (criança, adolescente, adulto e idoso);

2) Questões sobre sexualidade que surgem no cotidiano do profissional enfermeiro;

3) Vulnerabilidade às IST/aids e métodos contraceptivos (pílula anticoncepcional, pílula do dia seguinte, preservativo masculino e feminino)

4) Exercícios (dinâmicas)

5) Trabalhando a valorização da sexualidade e da vida

6) Avaliação 
IV) Estratégias:

Método: exposição oral (técnica: aula dialogal) e dinâmica de grupo (técnica: oficina pedagógica com diálogo, discussão e debate).

V) Recursos didáticos: sucata, diversos papéis, lápis preto e colorido, pincel atômico, bexiga, próteses, cartazes, materiais imantados, entre outros.

\section{Relato da oficina pedagógica realizada com os alunos de $1^{\circ}$ e $4^{\circ}$ ano}

Após contato prévio com os alunos, agendamos uma tarde para realizarmos a oficina pedagógica.

Os alunos compareceram ao local, que havia sido organizado com materiais educativos, preservativos, folhetos, entre outros. Cada aluno recebeu um crachá com o seu nome e foi solicitado que ficasse bem à vontade, podendo assim tirar o seu calçado e sentar-se ao chão.

Iniciamos a nossa oficina com a apresentação da coordenadora da oficina e da representante do Departamento de Enfermagem, para explicar aos alunos que o nosso trabalho estava aprovado pelo Departamento, assim como pelo Comitê de Ética.

A oficina foi direcionada principalmente para a realização de dinâmicas de grupo, discussões e debates. Segue abaixo a seqüência das nossas dinâmicas, as quais foram extraídas do Livro Adolescer, da Aben ${ }^{1}$ (2001).

\section{- $\mathbf{1}^{\text {a }}$ dinâmica: "Energização"}

Objetivo: Sintonizar com a energia existente no seu corpo e no ambiente; incentivar o aluno a sintonizar as suas energias naquela oficina que seria iniciada.

Duração: 15 minutos

Material: Sala ampla e música de relaxamento

Desenvolvimento:

\footnotetext{
${ }^{1}$ ABEN, Associação Brasileira de Enfermagem. Adolescer: compreender, atuar, acolher: Projeto Acolher. Brasília: ABEn, 2001, 304p.
} 
1. Todos em pé, formaram dois círculos concêntricos ficando de frente para um companheiro, mantendo os olhos fechados. Pedimos que todos respirassem bem fundo pelo nariz e soltassem lentamente a respiração pela boca. Repetiram 6 vezes. Pedimos que todos acompanhassem o ritmo de sua respiração.

2. Lentamente e calados, abriram os olhos e energizaram as mãos esfregando-as uma na outra. Em seguida levantaram as mãos, ficando com as palmas viradas para as do companheiro em frente. Fecharam os olhos para sentir a corrente energética que se formava. Depois de abrir os olhos, sacudiram as mãos, energizando o ambiente.

\section{- 2 $2^{a}$ dinâmica: "Balão no pé”}

Objetivo: Promover aquecimento e descontração do grupo para iniciar a discussão da temática em foco.

Duração: 10 minutos

Material: Sala ampla, 1 balão para cada participante, pedaços de barbante, aparelho de som e música alegre.

Desenvolvimento:

1. O coordenador solicitou ao grupo que ficassem no centro da sala, de pé;

2. Distribuímos um balão e um pedaço de barbante para cada participante;

3. Cada aluno encheu o seu balão, amarrou com o barbante e prendeu no tornozelo;

4. Iniciamos a música para todos dançarem;

5. A uma pausa da música, os alunos puderam estourar os balões dos outros;

6. O jogo terminou quando todos os balões haviam sido estourados.

\section{$\underline{\text { Avaliação }}$}

As primeiras dinâmicas tiveram como objetivo a integração entre os alunos.

Observamos que após as dinâmicas os alunos sentiram-se mais à vontade para iniciarmos a discussão sobre sexualidade humana. 
Neste momento notamos que o grupo apresentava uma grande expectativa em relação ao que iria acontecer durante a oficina pedagógica.

\section{- $3^{a}$ dinâmica: “O Semáforo”}

Objetivo: Identificar temas de maior interesse em sexualidade.

Duração: 1 hora

Material: Sala ampla e confortável, papel sulfite, canetinhas, 3 círculos de papel cartão nas cores vermelha, amarela e verde.

Desenvolvimento:

- Trabalho individual

1. O coordenador forneceu folha de papel sulfite e canetinha para cada participante;

2. Pedimos a cada um que dobrasse em três partes a folha de sulfite, no sentido do comprimento;

3. Em cada tira de papel (ou ficha), foi escrito uma palavra que correspondia a um tema de interesse próprio sobre sexualidade. Também foi permitido que se escrevesse uma pergunta ou frase sobre a temática em foco.

4. O coordenador colocou os três círculos distanciados, lado a lado, no chão da sala.

- Trabalho em grupo

1. Cada participante distribuiu as suas fichas pelos círculos ou "sinais do semáforo", dependendo do grau de dificuldade que sentia em debater sobre os temas. O sinal vermelho representava muita dificuldade sobre o assunto, o amarelo representava dificuldade média e o verde significava pouca dificuldade.

2. O coordenador pediu que os jovens passassem pelos círculos e lessem os temas escolhidos.

3. Após a leitura, foi pedido aos participantes que levantassem os temas mais abordados em cada círculo. 


\section{Assuntos que foram colocados no círculo vermelho:}

- Como agir quando recebemos muitos elogios e cantadas de pacientes e colegas de trabalho?

- Primeira relação sexual.

- Porque as pessoas ainda transam sem camisinha?

- Sexo ainda é visto de forma preconceituosa e vergonhosa por muitas pessoas!

- Gravidez antes de ter condições de criar a criança!

- Como e quando deve ser iniciada a educação sexual para crianças (na escola)?

- Sexo anal.

- Como conversar com pessoas com preferências sexuais para o mesmo sexo?

- Como falar com pessoas mais velhas que sejam "fechadas" (tímidas)?

- Exames sorológicos que devem ser feitos?

- O tamanho do pênis influencia no prazer?

- Porque algumas mulheres demoram para alcançar o orgasmo?

- Prostituição.

- O que as mulheres acham sobre a camisinha feminina?

- Como devemos abordar a importância do uso de preservativos para pessoas mais velhas?

\section{Assuntos que foram colocados no círculo amarelo:}

- Como incentivar a população marginalizada a se cuidar e utilizar os métodos preventivos?

- Qual o mais seguro dos métodos contraceptivos?

- Perda da libido.

- Quando o homem e a mulher devem procurar ajuda e orientação de profissionais?

- A primeira vez fica para sempre na lembrança!

- Como devemos lidar com o paciente que acaba de receber um resultado de exame que indica ser soro positivo? 
- Tratar sexualidade com os pacientes.

- Sexo na $3^{\mathrm{a}}$ idade.

- Prazer.

- Sexualidade na infância

- Tabus da população.

- O que os homens acham da camisinha feminina?

- Explicar IST para crianças e adolescentes.

\section{Assuntos que foram colocados no círculo verde:}

- Homossexualismo.

- Gravidez.

- Sexualidade dos idosos.

- Sexo sem amor.

- Impotência sexual.

- Orientação sexual.

- Ejaculação precoce.

- Sexo na Infância.

- Métodos contraceptivos (4)*

- Gravidez na adolescência (2)*

- Sexo antes do casamento.

- Pílula do dia seguinte.

- Sexualidade é natural de cada um.

- IST/Aids (2)*

- Quais os efeitos colaterais da pílula do dia seguinte?

\footnotetext{
* Este número representa o total de vezes em que apareceu esta resposta.
} 
- Diferença do sexo para homens e mulheres.

- Prostituição.

- Sexualidade de pessoas soropositiva.

- Sexo anal.

- Sexo oral.

- Masturbação.

- Sexo só vale a pena se for com a pessoa certa.

- Tem alguma IST que tem risco de esterilizar a pessoa?

- Camisinha feminina.

- Quais os métodos contraceptivos mais evoluídos?

- O que é mais importante nesse assunto quando se "trabalha" com adolescentes?

- Camisinha.

- Como abordar a sexualidade com os pacientes?

- Sexualidade é algo natural e não deve ser julgado!

- Frigidez.

- Virgindade.

- Sexualidade em diferentes culturas.

\section{$\underline{\text { Avaliação }}$}

Durante a realização dessa dinâmica notamos que alguns alunos tiveram dificuldade em colocar no papel algum assunto que envolvesse sexualidade. Acreditamos que esta dificuldade seja natural, uma vez que, a universidade oferece poucos espaços para se discutir esta temática.

Após os alunos terem lido cada ficha que estava em determinada cor do "semáforo", pedimos a todos que sentassem em círculo e iniciamos a discussão. 
Juntamente com os alunos a nossa primeira observação foi que a grande maioria das fichas estava no círculo verde, concluindo que os alunos tinham facilidade em lidar com os assuntos referentes à sexualidade.

Verificamos que havia alguns assuntos como, por exemplo, camisinha feminina, sexualidade na infância, sexualidade na $3^{\text {a }}$ idade, estavam presentes em mais de um círculo. Dessa maneira, levantamos a questão de que alguns dos participantes tinham facilidade de falar sobre determinado tema, enquanto outros tinham dificuldade de falar do mesmo tema. Diante do exposto ressaltamos que isso era muito bom, uma vez que poderiam contar com o outro colega quando se sentissem em dificuldade de dialogar sobre determinado assunto referente à sexualidade, reforçando a possibilidade de formação de agentes multiplicadores entre seus pares.

Como havia inúmeras questões, o coordenador solicitou ao grupo que selecionasse alguns dos temas que eles mais gostariam de discutir, e assim foram escolhidos:

- Sexualidade na infância

- Sexualidade na $3^{\mathrm{a}}$ idade

- Sexualidade da mulher

- Sexualidade do paciente com Diabetes Melitos

- Prostituição

- Métodos contraceptivos, dando ênfase a camisinha feminina, masculina e pílula do dia seguinte (a coordenadora optou por falar sobre este tema durante a $4^{\text {a }}$ dinâmica).

- Atuação do profissional enfermeiro em situações que ele teria que abordar a sexualidade.

Depois de selecionados os principais temas que os jovens gostariam de discutir, a coordenadora optou por expor alguns "casos" e assim desenvolver a discussão a partir deles. 


\section{- Apresentação e discussão dos casos}

Caso 1: Você chega à enfermaria de pediatria e encontra duas crianças, uma de 4 e outra de 5 anos manipulando o genital uma da outra. Qual o seu sentimento e qual a sua conduta?*

Algumas falas dos alunos:

Em relação ao sentimento:

"Ficaria nervosa"

"Repugnância"

"Coisa feia"

"Assustada"

Em relação à conduta:

"Eu chamaria a professora do estágio"

"Eu chamaria os pais das crianças"

"Eu não sei o que eu faria"

"Chamaria a psicóloga"

"Ficaria brava com as crianças e pediria que parassem"

"Conversaria com as crianças e perguntaria o que elas estavam fazendo"

\section{$\underline{\text { Avaliação }}$}

Assim como Ribeiro (1989) em seu estudo observamos que a maioria expressou sentimentos de bloqueio e reações de intervenção.

Acreditamos que isso nos evidencia uma dificuldade em lidar com esta situação, assim como uma não aceitação em relação ao comportamento sexual das crianças.

Quanto a conduta em relação a essa situação, alguns alunos referiram: solicitar ajuda profissional e/ou dos pais da criança; tentar interromper o processo de descoberta da sexualidade infantil através de uma atitude repressiva e por fim, esclarecer as curiosidades das crianças através do ato de conversar.

\footnotetext{
* Este caso foi extraído de RIBEIRO, M.O. Sentimentos e reações do aluno de enfermagem ante algumas situações
} relacionadas à sexualidade infantil. Rev. Esc. Enferm. USP, v.23, n.2, p.3-19, 1989. 
Ribeiro (1989) refere que quando as crianças estão tendo um contato manual, de visualização e inter-relacionamento entre elas, essas crianças estão satisfazendo suas curiosidades e não necessitam da presença de adultos para esclarecimentos.

As respostas dos alunos estudados conduzem à necessidade de discutir o assunto para assim evitar a reprodução de uma educação repressiva sobre a sexualidade infantil.

Caso 2: Uma mulher de 45 anos veio até o posto de saúde para fazer o exame de Papanicolau. Antes de iniciar o exame, a mulher referiu que o seu parceiro estava reclamando porque ela ficava muito molhada durante a relação sexual e que ele achava que isso não era normal. Qual a sua conduta diante desse caso?

Algumas falas dos alunos:

"Mas isso é normal?"

"Perguntaria se ela percebia que ficava molhada"

"Perguntaria se ela achava que aquilo era normal"

"Discutiria com o ginecologista"

"Chamaria o parceiro dela para podermos conversar melhor"

"Falaria que isso é normal, faz parte da lubrificação durante o ato sexual"

\section{$\underline{\text { Avaliação }}$}

Neste segundo caso notamos que a maioria dos alunos teve menos dificuldade em lidar com a situação, visto que tentaram investigar melhor o que realmente estava acontecendo com a paciente.

Observamos também que os sujeitos solicitaram a presença do parceiro, entendendo que a questão da lubrificação estava trazendo problemas para o relacionamento sexual do casal. 
Acreditamos que devido a presente situação estar relacionada à "mulher" e o grande número de alunos estudados serem do sexo feminino, verificamos uma maior facilidade em lidar com o assunto da lubrificação vaginal.

Caso 3: Uma mulher referindo ser prostituta procura você no Programa Saúde da Família para tirar algumas dúvidas sobre métodos contraceptivos. Como você abordaria essa mulher?

Algumas falas dos alunos:

"Conversaria com ela como se ela fosse uma mulher normal"

"Falaria normalmente com ela"

"Explicaria tudo o que ela gostaria de saber"

"Recomendaria que, além da camisinha, ela também fizesse alguns exames de sorologia"

"O fato de ser prostituta foi uma escolha dela e eu não posso julgá-la"

\section{$\underline{\text { Avaliação }}$}

Diante das respostas dos alunos observamos que a maioria tentou transparecer que lidaria com a prostituta com naturalidade, se preocupando com a contracepção, exames sorológicos entre outras dúvidas que a paciente poderia apresentar.

Caso 4: Sr. João, 65 anos, tem Diabete Mellitos há 20 anos. Você tem acompanhado este paciente há 3 anos. Na última consulta, ele reclamou que não está conseguindo ter ereção há mais de 1 ano. Qual a sua conduta?

Algumas falas dos alunos:

"Encaminharia para o urologista"

"Chamaria a professora responsável pelo estágio"

"Mas nessa idade..."

"Não tenho a mínima idéia do que eu faria"

"Porque será que esse senhor está tendo problema de ereção? Ele até que é novo..."

"Perguntaria mais sobre a vida sexual dele" 


\section{$\underline{\text { Avaliação }}$}

Apenas um aluno se preocupou em investigar melhor a vida sexual do paciente.

Alguns alunos reagiram como se o profissional enfermeiro não fosse capacitado para lidar com essa situação. Outros alunos acharam que o paciente estava muito novo para ter problemas de ereção.

Ressaltamos que em nenhum momento os alunos correlacionaram o fato de não ter ereção com a questão do Diabete Mellitos.

Isso nos faz pensar o quanto seria importante se cada disciplina ministrada no curso de enfermagem abordasse questões de sexualidade.

"Sexualidade humana é um assunto que não se esgota enquanto houver vida, somos sexuados desde o nascimento até a morte" (RIBEIRO, 1989, p.11).

\section{- $4^{\text {a }}$ dinâmica: “Cadeia de Transmissão”}

Objetivo: Reconhecer comportamentos vulneráveis, identificar a cadeia de transmissão e refletir sobre a vivência sexual responsável.

Duração: 30 minutos

Material: Aparelho de som, música alegre e fichas de papel com desenhos

Desenvolvimento:

1. Distribuir uma ficha com um desenho para cada participante

2. Legenda: 


\begin{tabular}{|c||c||}
\hline O & Fez uso do preservativo (metade do número de participantes) \\
\hline
\end{tabular}

\begin{tabular}{|l||l||}
\hline \multirow{4}{*}{} & Não fez uso de preservativo (metade do número de participantes) \\
\hline
\end{tabular}

\begin{tabular}{|l|l||}
\hline$\triangle$ & Portador do vírus HIV (ficha única) \\
\hline
\end{tabular}

3. Enquanto estivesse tocando a música, todos deveriam caminhar e dançar pela sala. Quando a música parasse, deveriam se aproximar de uma colega e copiar todos os desenhos da ficha do colega.

4. Colocamos novamente a música e, quando ela parasse, todos deveriam se aproximar de outro colega e copiar todos os desenhos da ficha do colega.

5. Repetimos esta operação por 4 ou 5 vezes.

6. Ao final, apresentamos a legenda de cada desenho e abrimos para discussão.

Tentamos promover uma reflexão sobre auto cuidado, vivência sexual prazerosa e responsável, vulnerabilidade e cadeia de transmissão.

Para facilitar a participação do grupo nas conclusões da vivência, levantamos os seguintes itens:

- Quem fez uso do preservativo, entrou em contato com a situação de risco, mas estava protegido. Quem não usou, ficou mais vulnerável a adquirir o vírus HIV.

- Algumas pessoas não usaram preservativo e não tiveram contato com o portador do HIV, mas estão vulneráveis em relação à Aids e tiveram sorte.

- Todas as vezes que a música parou, é como se tivéssemos trocado de parceiro (a) sexual. 
- Quando copiamos os desenhos do colega, são os relacionamentos anteriores que acompanham os novos relacionamentos.

Terminamos a nossa dinâmica falando sobre o preservativo masculino e feminino. Como durante no questionário e também na $3^{\mathrm{a}}$ dinâmica, alguns alunos citaram o uso da pílula do dia seguinte, decidimos dialogar sobre este método com o grupo.

\section{$\underline{\text { Avaliação }}$}

Foi possível observar que nesta última dinâmica os alunos ficaram espantados no momento em que o coordenador falou do significado de cada símbolo.

A grande intenção da coordenadora diante dessa dinâmica foi fazer com o aluno se percebesse responsável por todos os seus relacionamentos, e que em toda relação sexual você sempre deixa um pouco de si e leva uma pouco do outro.

Observamos a preocupação dos alunos ao final da dinâmica e acreditamos que o nosso objetivo de "faze-los refletir" foi alcançado.

Terminamos a nossa oficina em um clima de muita descontração. Ao final, foi pedido aos alunos que fizessem uma avaliação por escrito, e na saída todos receberam preservativo.

\section{Avaliação da oficina por parte dos estudantes}

Solicitamos aos alunos que escrevessem em um papel o que eles haviam achado da oficina, inclusive que colocassem sugestões.

Seguem abaixo as avaliações, em ordem decrescente:

- Gostou da oficina $(17)^{*}$

- Gostou de ter usado dinâmicas (13)*

- Gostou de poder ter conversado abertamente (9)*

\footnotetext{
* Este número representa as vezes em que apareceu esta resposta.
} 
- Aproveitou a oficina (9)*

- Gostou da discussão dos casos (5)*

- Gostou do trabalho (mestrado) (5)*

- Gostou de saber a atuação do enfermeiro (4)*

- Despertou o interesse em saber mais sobre sexualidade (3)*

- Gostou dos temas terem partido dos alunos

\section{Tivemos como sugestões:}

- Gostaria que a oficina durasse mais tempo (3)*

- Acho que o assunto tem que ser mais discutido na faculdade

- Estender este trabalho para os outros anos da enfermagem e também para os outros $\operatorname{cursos}(2)^{*}$

\section{$\underline{\text { Avaliação }}$}

Através da avaliação realizada pelos alunos seguido das sugestões, podemos observar o quanto esses sujeitos estão abertos a discutirem temas relacionados à sexualidade. Notamos que ao se falar em sexualidade grande parte dos sujeitos gostou da metodologia participativa como meio de trabalhar o tema.

Achamos interessante o fato do aluno perceber que o enfermeiro pode sim ser um profissional que trabalhe com sexualidade.

Ressaltamos que os dados encontrados durante esta pesquisa foi possível devido a utilização da metodologia da pesquisa-ação, a qual nos possibilitou uma melhor aproximação com os sujeitos pesquisados. 
CONSIDERAÇÕES FINAIS 
Por meio da metodologia da pesquisa-ação, foi possível alcançar os objetivos propostos no presente estudo.

Os sujeitos pesquisados encontram-se na faixa etária entre 18 a 25 anos, a maioria é do sexo feminino, são pessoas solteiros e moram fora do convívio familiar.

A primeira relação sexual, para a maioria dos jovens, ocorreu entre 17 e 18 anos, sendo o namorado(a) o parceiro(a) desta relação. O preservativo foi o método mais utilizado nesta relação, seguido do uso do preservativo associado ao anticoncepcional. Já na relação sexual atual, o método mais utilizado é o preservativo juntamente com o anticoncepcional, seguido do uso da pílula e em terceiro lugar o uso do preservativo. Esta mudança ocorreu principalmente entre os alunos do $4^{\circ}$ ano, período em que a maioria namora e assim, nessa fase, os jovens universitários tendem a substituir o preservativo pela pílula.

Tratando-se de uma geração que se formou num contexto em que a epidemia de Aids já estava claramente delineada, o risco do HIV é um elemento a mais a ser enfrentado no cenário da sexualidade. Percebe-se que, entre os alunos que estão finalizando a graduação, o relacionamento sexual é baseado no compromisso, fidelidade e confiança entre os pares, tendo desta forma a troca do preservativo pela pílula.

O uso sistemático do preservativo pode ser mais observado entre os alunos do $1^{\circ}$ ano, quando a maioria mantém relacionamentos esporádicos, não havendo ainda o "pacto de confiança” entre os parceiros.

A grande maioria dos alunos adquiriu conhecimento suficiente sobre sexualidade e IST/aids antes de ingressarem na universidade.

Os acadêmicos entendem que o papel da graduação em enfermagem é o de fornecer conhecimento/informação/esclarecimento sobre sexualidade e IST/aids. Grande parte dos alunos que estão saindo da graduação se sente preparada para lidar com temática junto aos seus futuros pacientes, enquanto uma outra parte dos sujeitos acredita que deveriam aprender 
mais sobre a temática para melhorar o atendimento aos seus pacientes e para a sua própria vida.

Para adquirir conhecimento sobre sexualidade e IST/aids, os alunos do $1^{\circ}$ ano apontaram tanto a metodologia de ensino menos participativa quanto a mais participativa. Já os alunos do $4^{\circ}$ ano a grande maioria sugeriu a metodologia mais participativa, como o uso de dinâmicas, debates, discussões e oficinas.

A metodologia participativa é interessante para trabalhar o aspecto afetivo-emocional do aluno de enfermagem, permitindo que ele descubra as suas dificuldades e potencialidades em relação ao trabalho com a temática sexualidade e IST/aids, junto aos seus pacientes e também para a sua vida pessoal.

A maioria dos alunos do $4^{\circ}$ ano vivenciou alguma experiência acadêmica em que tiveram que abordar a temática em apreço, ou seja, tiveram que ter conhecimento para lidarem com a situação. Dessa maneira, podemos verificar que o preparo desses futuros profissionais está diretamente interligado ao preparo de seus professores.

Durante a oficina pedagógica, notamos o grande interesse em saber mais sobre o tema, estando dispostos a estabelecerem um diálogo aberto entre educando e educador.

A partir dos resultados da oficina pedagógica percebeu-se a necessidade de abordar alguns temas como: sexualidade infantil, sexualidade na $3^{\text {a }}$ idade, entre outros, com mais profundidade e maior abrangência suscitando a continuação de novas pesquisas nessa área.

A população estudada merece atenção especial por parte de seus educadores, uma vez que, durante toda a nossa pesquisa, percebemos a motivação e o interesse em abordar a sexualidade humana e IST/aids.

Acreditamos que, dessa maneira, estaremos formando enfermeiros críticos, autênticos, reflexivos e abertos ao diálogo para discutir a temática em apreço. 
REFERÊNCIAS 
ABDO, C.H.N. Descobrimento sexual do Brasil. São Paulo: Summus, 2004

ABDO, C.H.N. Sexo pode ser. São Paulo: Prestígio, 2006.

ABEN Associação Brasileira de Enfermagem. Adolescer: compreender, atuar, acolher: Projeto Acolher. Brasília: ABEn, 2001.

AGGLENTON, P.J. Young people, life skills and HIV prevention. Paper prepared for UNICEF Informal Discussion on Life Skills Education. Princeton,1992. p.10.

AYRES, J.R.C.M. Vulnerabilidade e avaliação das ações preventivas. São Paulo: Casa das Edições, 1996.

AYRES, J.R.C.M. et al. Aids, vulnerabilidade e prevenção. In: Seminário Saúde Reprodutiva em Tempos de Aids, 2, 1997, Rio de Janeiro. Textos publicados. Rio de Janeiro: ABIA/IMS-UERJ, 1997.

BANDEIRA, V.M.P.; DIÓGENES, M.A.R. O uso do preservativo masculino e feminino entre os alunos de enfermagem da Universidade de Fortaleza. Rev. Enferm. UERJ., v.14, n.1, p.74-79, 2006.

BARROSO, C.; BRUSCHINI, C. Educação sexual: debate aberto. Petrópolis: Vozes, 1982.

BENTO, I.C.B. Problematização e pesquisa-ação em sexualidade, DST e Aids com universitários. 2000. 184f. Dissertação (Mestrado) - Escola de Enfermagem, Universidade de São Paulo, Ribeirão Preto.

BENTO, I.C.B. Educação preventiva em sexualidade, IST/aids para surdo através da pesquisa-ação. 2005. 104f. Tese (Doutorado) - Escola de Enfermagem, Universidade de São Paulo, Ribeirão Preto.

BRASIL. Ministério da Saúde. Secretaria da Assistência à Saúde. Programa Nacional de DST/Aids. Educação em saúde do escolar para prevenção de Aids e DST: um Programa de Recursos para Planejadores de currículo/Manual para Planejamento de currículo/Guia do Professor/Atividades dos Alunos. Brasília, 1995. p.10-21.

BRASIL. Ministério da Saúde. Pesquisa de conhecimento, atitudes e práticas relacionadas às Infecções Sexualmente Transmissíveis. Brasília: CNDST/AIDS, 2004.

BRASIL. Ministério da Saúde. Coordenação Nacional de DST e Aids. Cresce uso do preservativo na primeira relação sexual dos jovens brasileiros. Brasília: Programa Nacional de DST e Aids, 2005. Disponível em < $\underline{\text { http://www.aids.gov.br> }}$. Acesso em: 2 dez 2005. 
BRASIL. Ministério da Saúde. Plano estratégico do Programa Nacional de DST e AIDS. Brasília: CNDST/AIDS, 2005a.

BRASIL. Ministério da Saúde. Secretaria de Vigilância em Saúde. Programa Nacional de DST e Aids. Oficina de Aconselhamento em DST/HIV/AIDS para atenção básica. Brasília: Ministério da Saúde, 2005b.

BRASIL. Ministério da Saúde. Secretaria de Atenção à Saúde. Departamento de Ações Programáticas Estratégicas. Anticoncepção de Emergência: perguntas e respostas para profissionais de saúde.- Brasília: Ministério da Saúde, 2005c.

BRASIL. Ministério da Saúde. Secretaria de Vigilância em Saúde - Programa Nacional de DST e Aids. Bol Epidemiol Aids e DST, 2006. Disponível em < $\underline{\text { http://www.aids.gov.br }>}$ Acesso em: 12 mar. 2007.

BUENO, S.M.V.; COSTA, J.C.; BORELLI, O.C. Educação para promoção da Saúde Sexual/DST/Aids. Ribeirão Preto: Gráfica Editora Villimpress, 1995

BODGAN, R.C.; BILKEN, S.K. Fundamentos da investigação qualitativa em educação: uma introdução. In: BODGAN, R. C.; BILKEN, S. K. Investigação qualitativa em educação: uma introdução à teoria e aos métodos. Porto: Porto Editora, 1997. Cap.1, p.19-80.

BUENO, S.M.V. Marco conceitual e referencial teórico de educação para saúde: orientação à prevenção de DST/Aids e drogas no Brasil para crianças, adolescentes e adulto jovem. Brasília, 1997-1998. p.70-88.

BUENO, S.M.V.; Educação preventiva em sexualidade, DST-Aids e drogas nas escolas: pesquisa ação e o compromisso social. 2001. 263f. Tese (Livre Docência) - Escola de Enfermagem, Universidade de São Paulo, Ribeirão Preto.

CARVALHO, M.D.B. Professores das primeiras séries iniciais do $\mathbf{1}^{\mathbf{0}}$ grau: concepções de saúde e educação. 1992. 125f. Dissertação (Mestrado) Centro de Educação e Ciências Humanas, Universidade Federal de São Carlos, São Carlos.

CARVALHO, J.J.M. Falando sobre HPV: papilomavírus humano. São Paulo: Instituto Garnet, 2003.

DADOORIAN, D. Gravidez na adolescência: um novo olhar. Rev. Ciênc. Profissão (online), n.1, 2003. Disponível em: <http://www.revistacienciaeprofissao.org/artigos/ 23_01/artigo11_1.htm>. Acesso em: 10 ago.2005.

DOMINGUES, C.M.A.S. Identidade e sexualidade no discurso adolescente. São Paulo, 1997. 180f. Dissertação (Mestrado) Faculdade de Saúde Pública, Universidade de São Paulo, São Paulo. 
EGRY, E.Y. O docente de enfermagem e o ensino da sexualidade humana: ação educativa através da pesquisa participativa. 1985. 157f. Tese (Doutorado) - Faculdade de Saúde Pública, Universidade de São Paulo, São Paulo.

FREIRE, P. Educação como prática da liberdade. São Paulo: Paz e Terra, 1992.

FREIRE, P. Pedagogia da autonomia. São Paulo: Paz e Terra, 1996.

FREIRE, P. Papel da educação na humanização. Rev. Faeeba, n.7, p.7-10, jan/jun. 1997.

FREIRE, P. Pedagogia do oprimido. São Paulo: Paz e Terra, 2000, p. 65-116.

GALVÃO, M.T.G.; ALENCAR, R.A.; FERREIRA, M.L.S.M. Sexualidade e conhecimento das doenças sexualmente transmissíveis e Aids entre adultos em um município do interior do nordeste brasileiro. J. Bras. Doenças Sex. Transm., v.15, n.3, p.37-40, 2003.

GARCIA, T.R. Sexualidade humana: conhecimento necessário à formação do enfermeiro. Acta Paul. Enferm., v.6, n.1/4, p.39-42, 1993.

GIL, A.C.; TEMPORINI, E. R. Prevenção da aids entre estudantes universitários: existe influência dos pares? Medicina, v.33, p.147-154, 2000.

GIORDANI, A.T. Pesquisa-ação com mulheres detentas sobre sexualidade DST - aids e drogas. 2000. 170f. Dissertação (Mestrado) - Escola de Enfermagem, Universidade de São Paulo, Ribeirão Preto.

GIORDANI, A.T. Violência sexual e a vulnerabilidade às IST-aids em mulheres detentas. 2003. 551f. Tese (Doutorado) - Escola de Enfermagem de Ribeirão Preto, Universidade de São Paulo, Ribeirão Preto.

GIR, E.; DUARTE, G.; CARVALHO, M.J. Opinião de universitários sobre o uso do condom e sua influência no exercício da sexualidade. Medicina, v.30, p.100-105, 1997.

GIR, E.; NOGUEIRA, M.S.; PELÁ, N.T.R. Sexualidade humana na formação do enfermeiro. Rev.Latino-Am. Enferm., v.8, n.2, p.33-40, 2000.

GOMES, R.A. Análise de dados em pesquisa qualitativa. In: MINAYO, M.C.S. (Org.). Pesquisa social: teoria, método e criatividade. Petrópolis: Vozes, 1994. p. 67-79.

GREEN, L.W. et al. Planejamento em educação em saúde. São Paulo: USP, 1980, p.6.

JESUS, M.C.P. Educação sexual e compreensão da sexualidade na perspectiva da enfermagem. In: In: RAMOS, F. R. S.; MONTICELLI, M.; NITSCHKE, R. G. (Org.). Projeto Acolher: um encontro da enfermagem com o adolescente brasileiro. Brasília: ABEn/Governo Federal, 2000, 196p. 
MAMEDE, M.V. et al. Prevenção de Aids para mulheres no Brasil. Ribeirão Preto: Projeto Ministério da Saúde, PNDST-Aids/EERP- USP, 1996. 141p.

MIYASAKI, S.C.S.; BUENO, S.M.V. Pesquisa-ação sobre sexualidade, DST/Aids com enfermeiros professores de Escola de enfermagem. J. Bras. Doenças Sex. Transm., v.13, n.5, p.46-53, 2001.

MINAYO, M.C.S. Ciência, técnica e arte: o desafio da pesquisa social. In: MINAYO, M.C.S. Pesquisa social: teoria, método e criatividade. Petrópolis: Vozes, 1994. p. 51-66.

MINAYO, M.C.S. O desafio do conhecimento. 8. ed. São Paulo: Huncitec, 2004.

MURARO, R.M. Sexualidade, libertação e fé - Por uma erótica cristã: primeiras indagações. Petrópolis: Vozes, 1985.

NASCIMENTO, E. Aids - atitudes entre caminhoneiros de estrada. 1997. $219 f$. Dissertação (Mestrado) - Escola de Enfermagem, Universidade de São Paulo, Ribeirão Preto.

NASCIMENTO, E. Desenvolvimento de pesquisa-ação com caminhoneiros de estrada: trabalhando na problematização as questões voltadas à sexualidade, DST/aids e drogas. 2003. 242f. Tese (Doutorado) - Escola de Enfermagem, Universidade de São Paulo, Ribeirão Preto.

OLIVEIRA, M.A.F.C. Pesquisa-ação com escolares de $1^{\circ}$ e $2^{\circ}$ graus: alguns aspectos de educação preventiva sobre DST e Aids. 1997. 139p. Dissertação (Mestrado) - Escola de Enfermagem, Universidade de São Paulo, Ribeirão Preto.

OLIVEIRA, M.A.F.C.; BUENO, S.M.V. Comunicação educativa do enfermeiro na promoção da saúde sexual escolar Rev. Latino-Am. Enferm., v.5, n.3, p.71-81, 1997.

OLIVEIRA, S.B.; WEINSTEIN, A. C. Aids: duas décadas. Epidemia > Pandemia > Vulnerabilidade social. O que vem depois? In: BRASIL. Ministério da Saúde. Manual de prevenção de assistência em HIV/Aids para profissionais de saúde mental. Brasília: Ministério da Saúde, 2002, p.16-23.

ORGANIZAÇÃO MUNDIAL DA SAÚDE. Dados de DST. 2004. Disponível em: < http://www.aids.gov.br>. Acesso em: 10 ago. 2005.

PELÁ, N.T.R. et al. A sexualidade humana no contexto da assistência de enfermagem. Rev. Bras. Sex. Hum., v.6, n.1, p.99-113, 1995.

PEREIRA, V.M. Sexualidade e a formação do profissional de enfermagem. In: Gir, E. et al. Sexualidade em temas. Ribeirão Preto: FUNPEC-RP, 2000, Cap. 8, p.103-118.

PISSATO, M. Educação sexual da criança. Rev. Gaúch. Enferm., v.3, n.1, p.51-59, 1981. 
PIROTTA, K.C.M. Não há guarda chuva contra o amor: estudo do comportamento reprodutivo e de seu universo simbólico entre jovens universitários da USP. 2002. 317f. Tese (Doutorado) - Faculdade de Saúde Pública, Universidade de São Paulo, São Paulo.

PIROTTA, K.C.M.; SCHOR, N. Intenções reprodutivas e práticas de regulação da fecundidade entre universitários. Rev. Saúde Pública, v.38, n.4, p.495-502, 2004.

RAMADAM, Z.B.A.; ABDO, C.H.N. Sexualidade - trâmites, percalços e desvarios. In: ABDO, C. H. N. Sexualidade humana e seus transtornos. São Paulo: Lemos, 2001. p.1322.

RAMIN, C.S.A.; SOLER, Z.A.S.G. O ensino da sexualidade em "xeque" em um curso de enfermagem. In: SIMPÓSIO BRASILEIRO DE COMUNICAÇÃO EM ENFERMAGEM, 8., 2002, São Paulo. Anais eletrônicos... São Paulo: Escola de Enfermagem de Riberão Preto USP, Disponível em:<http://www.proceedings.scielo.br> Acesso em: 25 set. 2006.

RIBEIRO, M.O. Sentimentos e reações do aluno de enfermagem ante algumas situações relacionadas à sexualidade infantil. Rev. Esc. Enferm. USP, v.23, n.2, p.3-19, 1989.

RILEY, M.W.; NELSON, E.E. A observação sociológica: uma estratégia para um novo conhecimento social. Rio de Janeiro: Zahar, 1976.

ROSENSTOCK, I.M. Why people use health services. Milbank Mem. Fund., v.44, n.3, p.94-122, 1966.

ROSENSTOCK, I.M. Historical of the health belief model. Health Educ. Monog., v.22, n.4, p.328-335, 1974.

SOUZA, R.S. Compreendendo o portador HIV/Aids, usuários de drogas: segundo o modelo de crenças em saúde de Rosenstock. 1997. 189f. Dissertação (Mestrado) - Escola de Enfermagem, Universidade de São Paulo, Ribeirão Preto.

TAVARES, C.A. Orientação sexual para crianças e adolescentes: proposta para formação de enfermeiros como educadores sexuais. Rev. Paul. Enferm., v.5, n.1, p.8-11, 1985.

TIBA, I. A adolescência: o despertar do sexo. São Paulo: Gente, 1994.

THIOLLENT. M. Metodologia da pesquisa-ação. São Paulo: Cortez, 1992.

TRIVIÑOS, A.N.S. Introdução à pesquisa social em ciências sociais. São Paulo: Atlas, 1990. 
WARWICK, J.; KIPPAX, S. Effects of sex education on Young people and Aids research. In: AGGLENTON, P.; DAVIES, P.; HART, G. (Eds). Aids: individual, cultural and policy dimension. Basingstoke: Falmer Press, 1990. p.67-86.

WORLD HEALTH ORGANIZATION. Global Programme on Aids. School health education to prevent Aids and STD: a recourse package for curriculum planners. Hand book for curriculum planners, Students activities and Teachers’Guide. Geneva: WHO, 1993.

WORLD HEALTH ORGANIZATION. Guidelines for the manegement of sexually trnsmitted infections. Note. 1999. Geneva. 2001. Disponível em: <http://www.unaids.org/ whatsnew/press/eng/pressarc02/WAD02EpiPR_em.html> Acesso em: 03 mar. 2006.

VITIELLO, N. Reprodução e sexualidade: um manual para educadores. São Paulo: CEICH, 1994

VITIELLO, N. A educação sexual necessária. Rev. Bras. Sex. Hum., v.6, n.1, p.15-28, 1995.

VITIELLO, N. Um breve histórico do estudo da sexualidade humana. Rev. Bras. Med. Ginecol. Obstet., v.8, n.3, p.126-132, 1997. 
APÊNDICES 


\section{APÊNDICE A - Questionários $1^{\circ}$ e $4^{\circ}$ ano}

\section{ALUNOS DO $1^{\circ}$ ANO}

SUA PARTICIPAÇÃO É MUITO IMPORTANTE PARA QUE POSSAMOS CADA VEZ MAIS MELHORAR A FORMAÇÃO DOS ENFERMEIROS EM RELAÇÃO À SEXUALIDADE E AS IST/Aids. CONTAMOS COM A SUA COLABORAÇÃO. RESPONDA COM PRECISÃO AO QUESTIONÁRIO. NÃO É NECESSARIO SE IDENTIFICAR.

\section{I - DADOS SÓCIODEMOGRÁFICOS}

1) Idade: ( ) $\leq 17$ anos ( ) 18 a 19 anos ( ) 20 a 21 anos ( ) 22 a 23 anos ( ) 24 a 25 anos ( ) $\geq 25$ anos

2) Sexo: ( ) feminino ( ) masculino

3) Estado civil: ( ) solteiro(a) ( ) união sem vínculo matrimonial ( ) casado(a) ( ) Outros:

4) Religião: ( ) católico ( ) protestante ( ) evangélico ( ) budista ( ) espírita ( ) outra

5) Atualmente esta morando: ( ) na casa dos pais ( ) sozinho ( ) com amigos ( ) outros

\section{II - QUESTÕES SOBRE A TEMÁTICA DA PESQUISA PROPRIAMENTE DITA}

- Conhecimento geral sobre o comportamento sexual, tendo em vista a sexualidade, riscos às IST/aids e métodos contraceptivos.

1) No momento você está namorando? : ( ) sim （ ) não

2) Você mantém relacionamentos esporádicos? : ( ) sim ( ) não

3) Iniciou a vida sexual ( $1^{\circ}$ relação sexual)? : ( ) sim ( ) não [Se você respondeu "não" pule para a questão ${ }^{\circ}$ 15]

4) Com quantos anos você teve a $1^{\circ}$ relação sexual? : anos

5) A sua primeira relação sexual foi com quem?: ( ) colega de turma ( ) garota de programa

$$
\text { ( ). namorado (a) ( ) outro }
$$

6) Você fez uso de algum tipo de método contraceptivo? ( ) sim [vá para a questão nº7]

$$
\text { ( ) não [vá para a questão }{ }^{\circ} 08 \text { ] }
$$

7) Se SIM qual foi o método contraceptivo usado?
( ) preservativo masculino
( ) injeção anticoncepcional
( ) DIU
( ) coito interrompido
( ) pílula anticoncepcional
( ) preservativo feminino ( ) tabelinha ( ) Outro

8) Se NÃO fez uso de nenhum método contraceptivo na $1^{\circ}$ relação sexual, por quê?

9) No seu relacionamento atual (namoro, "ficar", casamento, entre outros), você e/ou seu parceiro (a) usam algum tipo de método contraceptivo?

( ) sim, qual(is)?

Onde você adquire esse método contraceptivo?

( ) não, por que?

10) (Somente para pessoas que fazem uso da camisinha) Você já deixou de fazer uso da camisinha em alguma relação sexual? ( ) sim ( ) não

Se SIM, por que?

Se NÃO, por que?

11) Quantos parceiros (as) sexuais você teve neste último ano? parceiros (as)

12) Você já adquiriu algum tipo de IST (Infecções Sexualmente Transmissíveis)?
( ) $\operatorname{sim}$ [vá para questão ${ }^{\circ} 13$ ]
( ) não.[ vá para a questão ${ }^{\circ} 15$ ]

13) Se SIM, qual?

14) Onde você procurou tratamento para a IST (infecções sexualmente transmissíveis)?
( ) serviços de saúde
( ) amigos/colegas
( ) farmácia
( ) outro

15) Na sua opinião, classifique o grau de risco em adquirir alguma IST cada tipo de relação sexual abaixo: 
Sexo anal - ( ) grande risco ( ) pequeno risco ( ) médio risco ( ) nenhum risco

Sexo vaginal - ( ) grande risco ( ) pequeno risco ( ) médio risco ( ) nenhum risco

Sexo oral - ( ) grande risco ( ) pequeno risco ( ) médio risco ( ) nenhum risco

Sexo com camisinha (durante toda a relação sexual)- ( ) grande risco ( ) pequeno risco ( ) médio risco ( ) nenhum risco

16) Como você analisa o seu comportamento sexual em relação ao risco de você adquirir alguma IST (infecções sexualmente transmissíveis)?

R:

- Conhecimento prévio sobre sexualidade e prevenção às IST/aids, antes de ingressar à faculdade.

1) Durante sua vida como foi que você adquiriu informações sobre sexualidade e as IST (Infecções Sexualmente Transmissíveis)?

( ) Família (pai, mãe, irmãos) ( ) escola （ ) amigos ( ) meios de comunicação (TV, rádio, revista, jornal)

( )outros

2) Antes de você ingressar na faculdade qual era o seu grau de conhecimento sobre a prevenção das IST/aids?

( ) nenhum conhecimento ( ) pouco conhecimento ( ) conhecimento suficiente

- Dados sobre o papel da graduação na formação do aluno sobre sexualidade e IST/aids

1) Para a sua formação enquanto enfermeiro, o que você espera que a graduação em enfermagem lhe ofereça de conhecimento sobre a temática sexualidade e IST/aids?

$\mathrm{R}:$

2) Como você acha que seria a melhor maneira de construir o conhecimento sobre o tema sexualidade humana, IST/aids durante a graduação em enfermagem?

$\mathrm{R}:$

- Subsídios para trabalhar às necessidades

1) Gostaria de participar de uma oficina de trabalho, onde estaremos desenvolvendo junto com vocês atividades educativas sobre sexualidade humana e IST/aids? (Essas atividades têm a finalidade de abrir um espaço para que possamos dialogar e discutirlsobre o tema da pesquisa. A data da oficina ainda será agendada).

( ) $\operatorname{sim} \quad$ ( ) não

2) Livre para expressar o que você quiser (Sugestões, comentários, críticas).

$\mathrm{R}:$

OBRIGADA POR TER COLABORADO COM A NOSSA PESQUISA. A SUA PARTICIPAÇÃO FOI DE EXTREMA IMPORTÂNCIA PARA A REALIZAÇÃO DESTE TRABALHO. MUITO OBRIGADA!!

\section{ALUNOS DO $4^{\circ}$ ANO}

SUA PARTICIPAÇÃO É MUITO IMPORTANTE PARA QUE POSSAMOS CADA VEZ MAIS MELHORAR A FORMAÇÃO DOS ENFERMEIROS EM RELAÇÃO À SEXUALIDADE E AS IST/Aids. CONTAMOS COM A SUA COLABORAÇÃO. RESPONDA COM PRECISÃO AO QUESTIONÁRIO. NÃO É NECESSARIO SE IDENTIFICAR.

\section{I - DADOS SÓCIODEMOGRÁFICOS}

1) Idade: ( ) $\leq 17$ anos ( ) 18 a $19 \operatorname{anos}$ ( ) 20 a 21 anos ( ) 22 a 23 anos ( ) 24 a 25 anos ( ) $\geq 25$ anos

2) Sexo: ( ) feminino ( ) masculino

3) Estado civil: ( ) solteiro(a) （ ) união sem vínculo matrimonial ( ) casado(a) ( ) Outros:

4) Religião: ( ) católico ( ) protestante ( ) evangélico ( ) budista ( ) espírita ( ) outra

5) Atualmente esta morando: ( ) na casa dos pais ( ) sozinho ( ) com amigos ( ) outros

\section{II - QUESTÕES SOBRE A TEMÁTICA DA PESQUISA PROPRIAMENTE DITA}

- Conhecimento geral sobre o comportamento sexual, tendo em vista a sexualidade, riscos às IST/aids e métodos contraceptivos. 
1) No momento você está namorando?: ( ) sim ( ) não

2) Você mantém relacionamentos esporádicos? : ( ) sim ( ) não

3) Iniciou a vida sexual ( $1^{\circ}$ relação sexual)? : ( ) sim ( ) não [Se você respondeu "não" pule para a questão $n^{\circ} 15$ ]

4) Com quantos anos você teve a $1^{\circ}$ relação sexual? : anos

5) A sua primeira relação sexual foi com quem? : ( ) colega de turma ( ) garota de programa

( ) namorado (a) ( ) outro

6) Você fez uso de algum tipo de método contraceptivo? ( ) sim [vá para a questão nº7]

( ) não [vá para a questão nº8 ]

7) Se SIM qual foi o método contraceptivo usado?
( ) preservativo masculino
( ) injeção anticoncepcional
( ) DIU
( ) coito interrompido
( ) pílula anticoncepcional
( ) preservativo feminino ( ) tabelinha ( ) Outro

8) Se NÃO fez uso de nenhum método contraceptivo 1 na $1^{\circ}$ relação sexual, por quê?

9) No seu relacionamento atual (namoro, "ficar", casamento, entre outros), você e/ou seu parceiro (a) usam algum tipo de método anticoncepcional?

( ) sim, qual(is)?

Onde você adquire esse método contraceptivo?

( ) não, por que?

10) (Somente para pessoas que fazem uso da camisinha) Você já deixou de fazer uso da camisinha em alguma relação sexual? ( ) sim ( ) não

Se SIM, por que?

Se NÃO, por que?

11) Quantos parceiros (as) sexuais você teve neste último ano? parceiros (as)

12) Você já adquiriu algum tipo de IST (Infecções Sexualmente Transmissíveis)?
( ) sim [vá para questão $n^{\circ} 13$ ]
( ) não.[ vá para a questão ${ }^{\circ} 15$ ]

13) Se SIM, qual?

14) Onde você procurou tratamento para a IST (infecções sexualmente transmissíveis)?
( ) serviços de saúde
( ) amigos/colegas
( ) farmácia
( ) outro

15) $\mathrm{Na}$ sua opinião, classifique o grau de risco em adquirir alguma IST cada tipo de relação sexual abaixo:

Sexo anal - ( ) grande risco ( ) pequeno risco ( ) médio risco ( ) nenhum risco

Sexo vaginal - ( ) grande risco ( ) pequeno risco ( ) médio risco ( ) nenhum risco

Sexo oral - ( ) grande risco ( ) pequeno risco ( ) médio risco ( ) nenhum risco

Sexo com camisinha (durante toda a relação sexual)- ( ) grande risco ( ) pequeno risco ( ) médio risco ( ) nenhum risco

16) Como você analisa o seu comportamento sexual em relação ao risco de você adquirir alguma IST (infecções sexualmente transmissíveis)?

$\mathrm{R}$ :

- Conhecimento prévio sobre sexualidade e prevenção às IST/aids, antes de ingressar à faculdade.

1) Durante sua vida como foi que você adquiriu informações sobre sexualidade e as IST (Infecções Sexualmente Transmissíveis)?
( ) Família (pai, mãe, irmãos) ( ) escola
( ) amigos ( ) meios de comunicação (TV, rádio, revista, jornal)
( )outros

2) Antes de você ingressar na faculdade qual era o seu grau de conhecimento sobre a prevenção das IST/aids?
( ) nenhum conhecimento
( ) pouco conhecimento
( ) conhecimento suficiente

- Dados sobre o papel da graduação na formação do aluno sobre sexualidade e IST/aids 
1) Você acredita que o que a graduação em enfermagem lhe oferece de informações sobre sexualidade humana e as IST/aids, é o suficiente para que você possa desenvolver o seu trabalho como enfermeiro quando sair da faculdade? Por quê? $\mathrm{R}$ :

2) Além do conhecimento sobre sexualidade humana e IST/aids que a graduação em enfermagem já ofereceu para você, o que mais você acredita que a graduação em enfermagem poderia fornecer para que você pudesse atuar com mais "segurança" em relação à sexualidade humana e IST/aids diante dos seus futuros pacientes? Apresente sugestões.

$\mathrm{R}:$

3) Em qual (ais) disciplina (as) você teve contato com o tema sexualidade e IST/aids?

$\mathrm{R}:$

4) Como você acha que seria a melhor maneira de aprender sobre o tema sexualidade humana, IST/aids durante a graduação em enfermagem?

$\mathrm{R}:$

5) Você já passou por alguma situação durante a graduação em enfermagem (p. ex: estágios) em que você teve que ter conhecimento sobre o tema sexualidade/IST/aids?
( ) $\operatorname{sim}$
( )não

5a) Se sim, descreva rapidamente a situação vivida por você.

$\mathrm{R}:$

5b) Qual é ou foi o sentimento que você teve ao ter que abordar o tema sexualidade/IST/aids com um paciente? $\mathrm{R}$ :

\section{- Subsídios para trabalhar às necessidades}

1) Gostaria de participar de uma oficina de trabalho, onde estaremos desenvolvendo junto com vocês atividades educativas sobre sexualidade humana e IST/aids? (Essas atividades têm a finalidade de abrir um espaço para que possamos dialogar e discutirlsobre o tema da pesquisa. A data da oficina ainda será agendada).

$$
\text { ( ) } \operatorname{sim} \quad \text { ( ) não }
$$

2) Livre para expressar o que você quiser (Sugestões, comentários, críticas).

$\mathrm{R}:$

OBRIGADA POR TER COLABORADO COM A NOSSA PESQUISA. A SUA PARTICIPAÇÃO FOI DE EXTREMA IMPORTÂNCIA PARA A REALIZAÇÃO DESTE TRABALHO. MUITO OBRIGADA!! 


\section{APÊNDICE B - Termo de Consentimento Livre e Esclarecido}

Meu nome é Rúbia de Aguiar Alencar ${ }^{1}$, sou Enfermeira, atualmente estou trabalhando como professora do Curso de Graduação em Enfermagem da Faculdade Marechal Rondon em São Manuel/SP e na Faculdades Integradas de Jaú, em Jaú/SP e sou mestranda em Enfermagem Psiquiátrica da Escola de Enfermagem de Ribeirão Preto - USP.

Você está sendo convidado (a) para participar de uma pesquisa, a qual será a minha dissertação de mestrado, que tem como Titulo "Pesquisa-ação sobre vulnerabilidade, sexualidade e IST/aids com universitários da graduação em enfermagem".

Este projeto é orientado pela Profa. Dra. Sônia Maria Villela Bueno (Docente da Escola de Enfermagem de Ribeirão Preto - USP) e também conta com a colaboração e supervisão da Profa. Dra. Eliana Mara Braga ${ }^{2}$ (Docente do Departamento de Enfermagem - FMB - Unesp).

Esta pesquisa tem como objetivo geral investigar os fatores de vulnerabilidade entre os universitários de um Curso de Graduação em Enfermagem para o risco de contaminação com as IST/aids, refletindo, através de ações educativas, meios de aprimorar o seu conhecimento sobre a temática sexualidade e IST/aids na sua vida pessoal e profissional.

Para participar desta pesquisa você precisará responder algumas perguntas, na qual irá assinalar com um "X", ou escrever sua resposta no questionário anexo.

Após responder o questionário você será convidado a participar de uma oficina de trabalho onde serão discutidas temáticas sobre sexualidade e IST/Aids.

Neste encontro teremos a realização de dinâmica de grupo, discussões em grupo e outros tipos de atividades.

Durante todas as atividades do grupo eu como autora do projeto participarei de todos os encontros na qualidade de observadora participante e facilitadora das atividades.

Em nenhum momento haverá identificação de seu nome, tudo o que for falado, assinalado ou escrito será sigiloso.

Ressalto que você tem total liberdade de recusar ou retirar o consentimento a qualquer tempo.

Estamos à disposição para maiores esclarecimentos.

de de 2006

Rúbia de Aguiar Alencar

Nome:

Assinatura do aluno

\footnotetext{
${ }^{1}$ Rúbia de Aguiar Alencar. Endereço: Rua: Antônio Amando de Barros, ${ }^{\circ}$ 240, Apto 81, Bloco 03, Jardim Souza Santos, Botucatu/SP. Telefone: (14) 3815 8204. E-mail: rubia_enf@yahoo.com.br

${ }^{2}$ Eliana Mara Braga. Endereço: Rua: Carlos Guadagnini, n 1214, CEP: 18610-120. Botucatu/SP. Telefone:

(14) 3811 6070. E-mail: elmara@fmb.unesp.br
} 
ANEXOS

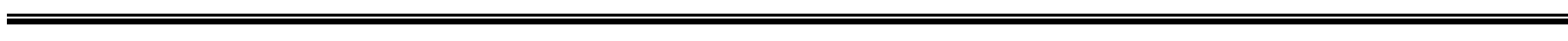




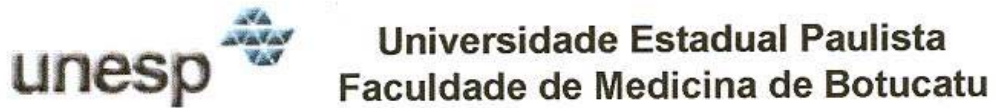

Distrito Rubião Junior, $s / n^{\circ}-$ Botucatu - S.P.

CEP: $18.618-970$

Fone/Fax: (0xx14) 3811-6143

e-mail secretaria: capellup@fmb.unesp.br

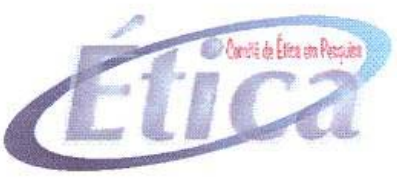

Registrado no Ministério da Saúde em 30 de abril de 1997

Botucatu, 07 de agosto de 2.006

OF.371/2006-CEP

Ilustríssima Senhora

Prof . Dr . Eliana Mara Braga

Departamento de Enfermagem da

Faculdade de Medicina de Botucatu

Prezada Eliana,

De ordem da Senhora Coordenadora deste CEP, informo que o Projeto de Pesquisa "Pesquisaação em uma população universitária do curso de graduação em enfermagem sobre a sexualidade de IST/aids", a ser conduzido por Rúbia de Aguiar Alencar, orientada pela Prof ${ }^{n}$ $D r^{a}$ Sônia Maria Villela Bueno, e com Supervisão de Vossa Senhoria, recebeu do relator parecer favorável, aprovado em reunião de 07/08/2006.

Situação do Projeto: APROVADO.

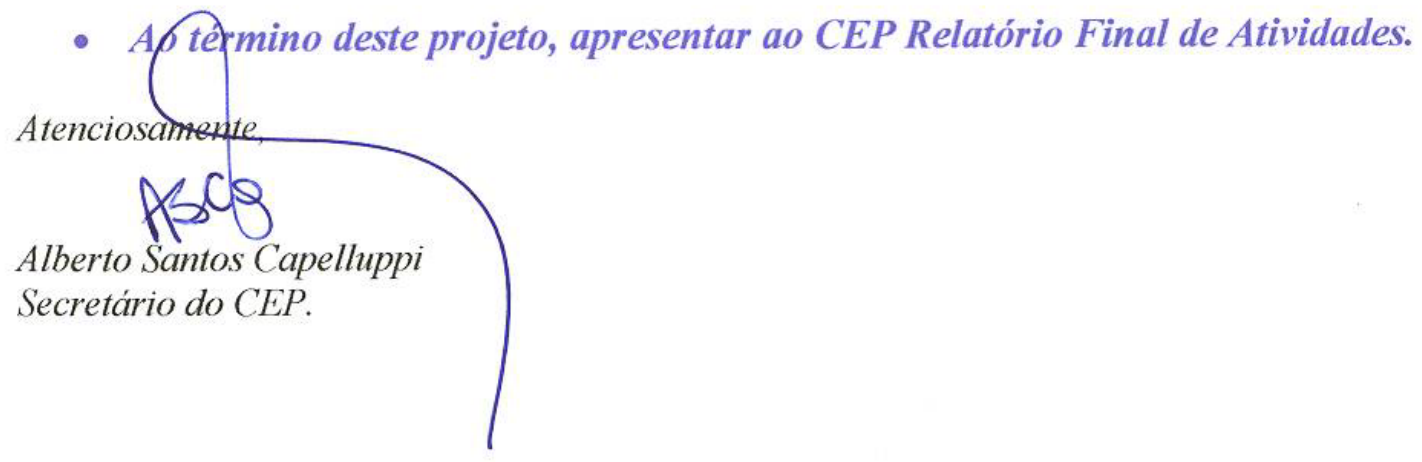




\section{ANEXO B}

unesp

DIVISĀO TECNICA ACADEMICA
UNIVERSIDADE ESTADUAL PAULISTA

CÂMPUS DE BOTUCATU

FACULDADE DE MEDICINA

Seção de Pós-Graduação
Fls.

Proc.

Rub.

BOTUCATU, SP - RUBIÃO JÚNIOR - CEP 18618-970 - PABX (0xx14) 3811-6022

\section{JUSTIFICATIVA DE ALTERAÇÃO NO TÍTULO DO PROJETO DE PESQUISA}

Declaramos que o Projeto de Pesquisa "Pesquisa-ação em uma população universitária do curso de graduação em enfermagem sobre sexualidade e IST/aids" aprovado pelo CEP em 07/08/2006, teve seu título alterado para "Pesquisa-ação sobre sexualidade e vulnerabilidade às IST/aids com alunos de graduação em enfermagem", sem nenhuma alteração no seu conteúdo metodológico da época de apresentação para análise do CEP.

A presente alteração foi efetuada somente para adequação do título da Dissertação de Mestrado.

Botucatu, 10/05/2007

Nome/Assinatura da aluna: Rúbia de Aguiar Alencar

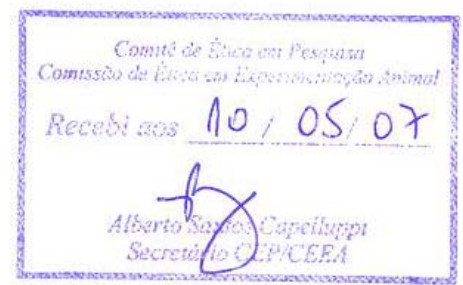

PHencer

Nome/Assinatura da supervisora do projeto: Eliana Mara Braga

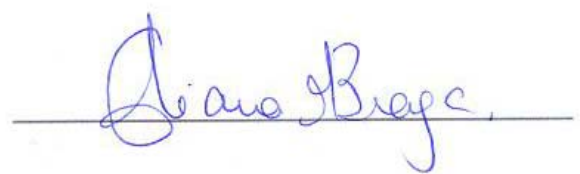

Programa de Pós Graduação em Enfermagem Psiquiátrica da Escola de Enfermagem de Ribeirão Preto - USP 